\title{
The Manti, Utah, Landslide
}

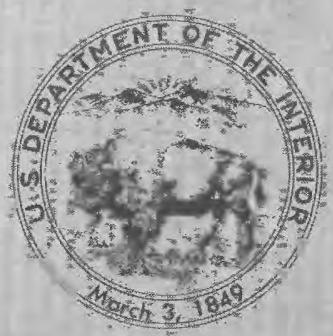

\section{U.S. GEOLOGICAL SURVEY PROFESSIONAL PAPER 1311}

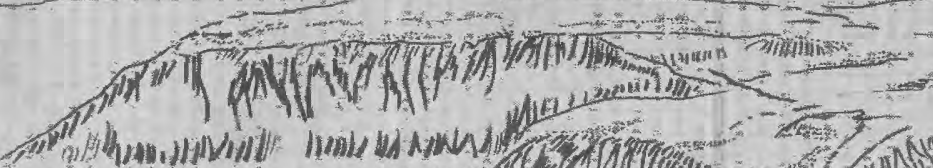

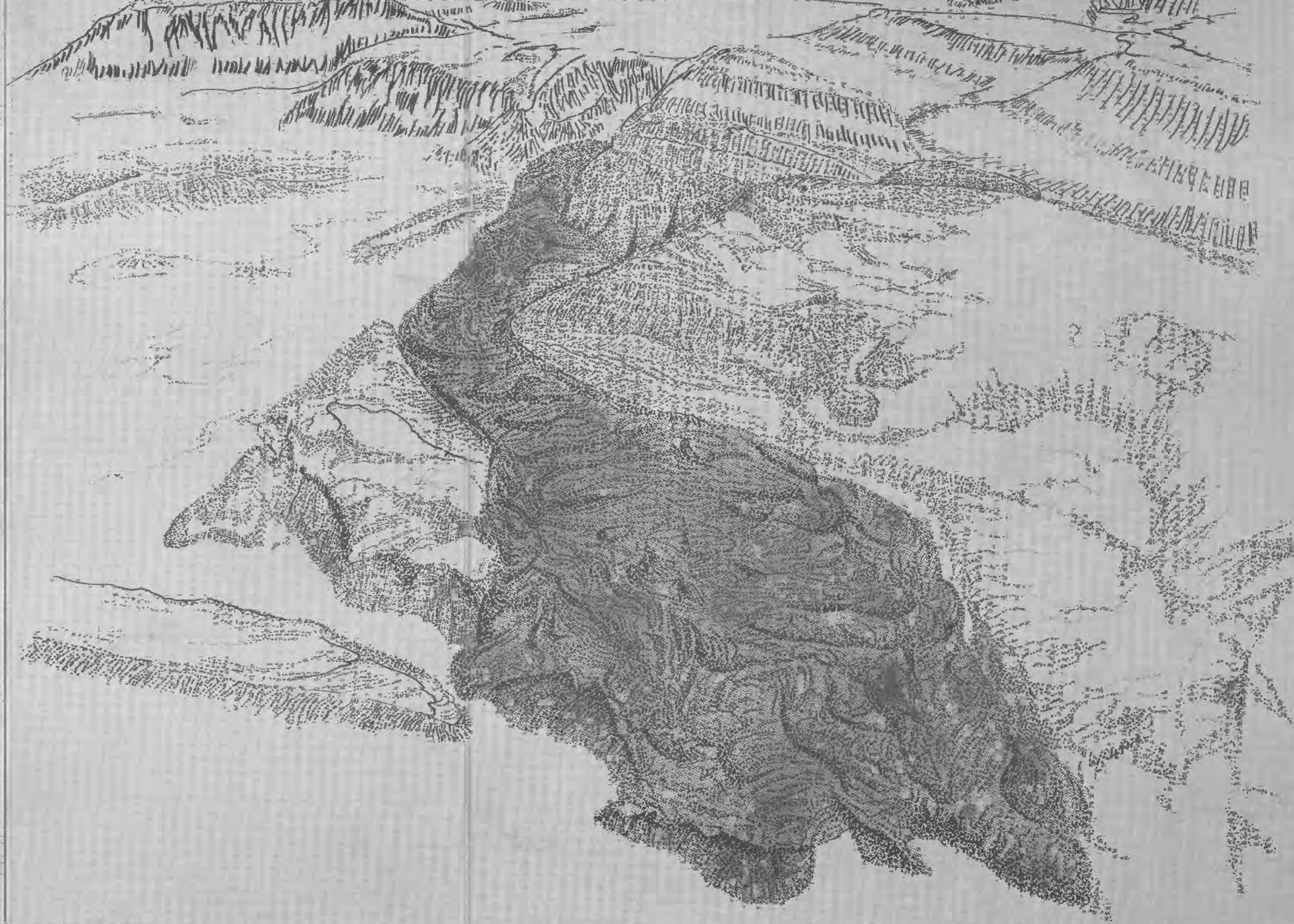


Cover artwork by Anthony G. Sanchez

Cover design by Norma J. Maes 
THE MANTI, UTAH, LANDSLIDE 


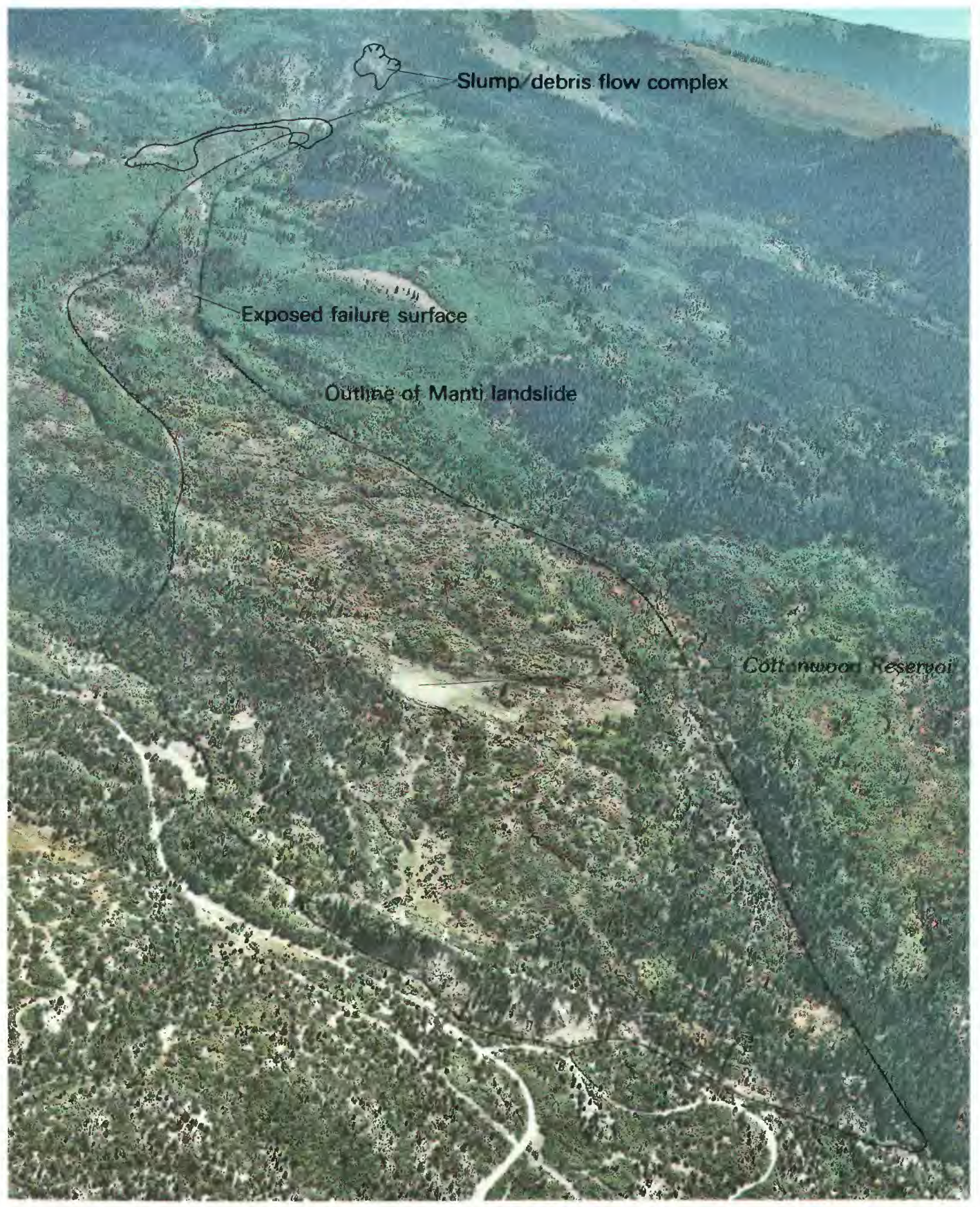

FRONTISPIECE.-Southeast aerial view of the Manti landslide taken on September 19, 1975. The lower part of the landslide, near Cottonwood Reservoir, was moving about $3 \mathrm{~m} /$ day, while the upper part was moving about $0.3 \mathrm{~m} /$ day (U.S. Forest Service photograph). 


\section{The Manti, Utah, Landslide}

The Reactivation of the Manti Landslide, Utah

By R. W. FLEMING, R. B. JOHNSON, and R. L. SCHUSTER

Physical Properties and Mode of Failure of the

Manti Landslide, Utah

By R. W. FLEMING, R. L. SGHUSTER, and R. B. JOHNSON

Stream-Channel Changes and Pond Formation at the 1974-76

Manti Landslide, Utah

By G. P. WILLIAMS

U.S. GEOLOG I A L S UR VEY PROFESSIONAL PAPER 1311

Contains a history of the reactivation of the Manti

landslide including rates of landslide enlargement

and displacement, morphologic changes, physical

properties of the landslide debris, and hydrologic changes

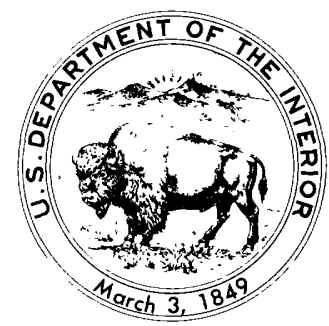

UNITED STATES GOVERNMENT PRINTING OFFICE, WASHINGTON: 1988 


\section{DEPARTMENT OF THE INTERIOR \\ DONALD PAUL HODEL, Secretary}

\section{U.S. GEOLOGICAL SURVEY}

Dallas L. Peck, Director

\section{Library of Congress Cataloging-in-Publication Data}

The Manti, Utah, Landslide.

(U.S. Geological Survey professional paper ; 1311)

Includes bibliographies.

Contents: the reactivation of the Manti landslide, Utah / by R.W. Fleming, R.B. Johnson, and R.L. Schuster-Physical properties and mode of failure of the Manti landslide, Utah / by R.W. Fleming, R.L. Schuster, and R.B. Johnson-Stream-channel changes and pond formation at the 1974-76 Manti landslide, Utah / by G.P. Williams.

Supt. of Docs. no.: I 19.16:1311-A-C

1. Landslides-Utah-Manti Region. 2. Slopes (Physical geography)-Utah-Manti Region. 3. Hydrology-Utah-Manti Region. I. Fleming, Robert W. Reactivation of the Manti landslide, Utah. 1987. III. Williams, Garnett P. Stream-channel changes and pond formation at the 1974-76 Manti landslide, Utah. 1987.

IV. Series: Geological Survey professional paper ; 1311.

QE599.U5M36 $1987 \quad 551.3$ '53

$86-600293$

For sale by the Books and Open-File Reports Section, U.S. Geological Survey, Federal Center, Box 25425, Denver, CO 80225

Any use of trade names in this publication is for descriptive purposes only and does not imply endorsement by the U.S. Geological Survey. 


\section{CONTENTS}

[Letters designate the chapters]

(A) The reactivation of the Manti landslide, Utah, by R. W. Fleming, R. B. Johnson, and

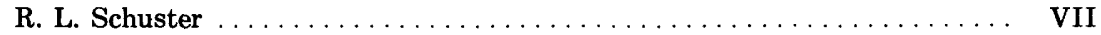

(B) Physical properties and mode of failure of the Manti landslide, Utah, by R. W. Flem-

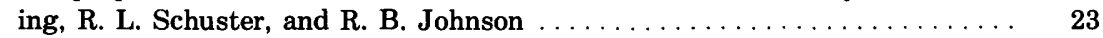

(C) Stream-channel changes and pond formation at the 1974-76 Manti landslide, Utah,

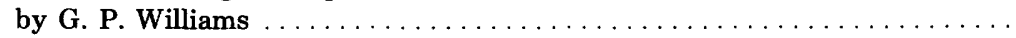





\section{The Reactivation of the Manti Landslide, Utah}

By ROBERT W. FLEMING, ROBERT B. JOHNSON, and ROBERT L. SCHUSTER

THE MANTI, UTAH, LANDSLIDE

U.S. GEOLOGICAL SURVEY PROFESSIONAL PAPER 1311 -A

Geologic and geographic setting of Manti Canyon and a description of the reactivation of the Manti landslide 



\section{CONTENTS}

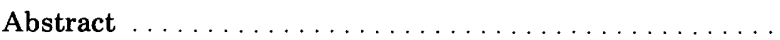

Introduction

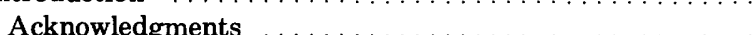

Geologic and geographic setting $\ldots \ldots \ldots \ldots \ldots \ldots$

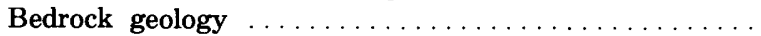

Geologic structure $\ldots \ldots \ldots \ldots \ldots \ldots \ldots \ldots \ldots \ldots$

Landslide deposits $\ldots \ldots \ldots \ldots \ldots \ldots \ldots \ldots$

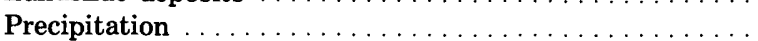

Triggering conditions and the initiation of movement ....
\end{abstract}

\begin{tabular}{|c|c|c|}
\hline Page & & Page \\
\hline 1 & Triggering conditions-Continued & \\
\hline 1 & Slump/debris-flow complex ... & 5 \\
\hline 2 & The beginning of reactivation & 6 \\
\hline 2 & Propagation of landslide movement & 9 \\
\hline 2 & Summary of displacement $\ldots \ldots$ & 17 \\
\hline 3 & Socioeconomic impacts of the reactivation of the Manti & \\
\hline 3 & 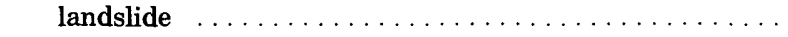 & 17 \\
\hline 4 & Concluding remarks .. & 20 \\
\hline 5 & References cited ... & 21 \\
\hline
\end{tabular}

\section{ILLUSTRATIONS}

Plate

FIGURE

1. Map and cross section of Manti landslide.

Page

1. Map showing the location of the Manti landslide, the drainage basin of Manti Creek, and the city of Manti ... 3

2. Aerial photographs of a portion of Manti Canyon showing two views of the Wasatch monocline ..........4

3. Profile showing average precipitation as a function of altitude and distance from canyon mouth for four stations in Ephraim Canyon and one station at Manti

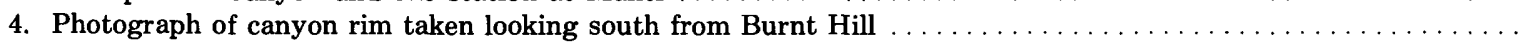

5. Sketch of a U.S. Forest Service photograph of the slump/debris-flow complex showing the slumps and a lobe of debris from the west slump just as it reached the depositional area $\ldots \ldots \ldots \ldots \ldots \ldots \ldots \ldots \ldots \ldots \ldots \ldots \ldots \ldots$

6. Photographs of initial landslide crack on the right flank of the landslide near the waterline crossing $\ldots \ldots \ldots \ldots$ 7-11. Maps:

7. Outline of the inactive Manti landslide from pre-1974 aerial photography $\ldots \ldots \ldots \ldots \ldots \ldots \ldots \ldots$

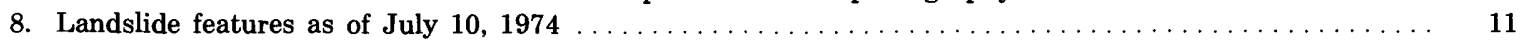

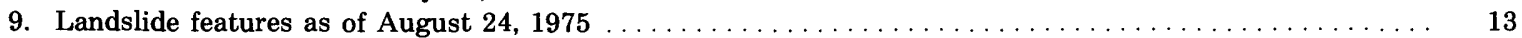

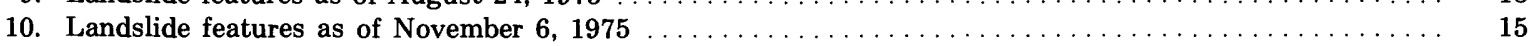

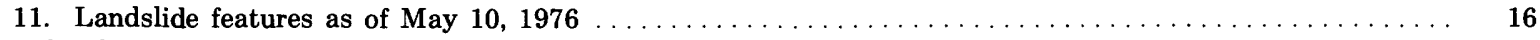

12. Graphs showing displacement, displacement rate, and precipitation versus time for the period May-August $1976 \quad 18$

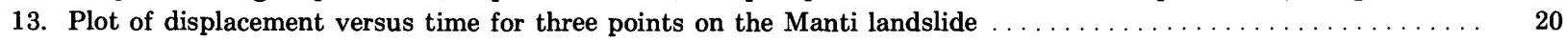

14. Photograph showing $4 \mathrm{~m}$ of offset of road at crossing of the east flank of the landslide near the former waterline crossing

\section{TABLES}

TABLE 1. Sources of information on costs of landslide damage in Manti, Utah . . . . . . . . . . . . . . . .

2. Expenditures by governmental agencies on the landslide in Manti Canyon (June 1974-August 1976) $\ldots \ldots \ldots \ldots 22$ 


\section{CONVERSION TABLE}

\begin{tabular}{|c|c|c|}
\hline Multiply SI units & by & To get inch-pound units \\
\hline & Length & \\
\hline millimeter $(\mathrm{mm})$ & 0.03937 & inch (in.) \\
\hline meter $(\mathrm{m})$ & 3.281 & foot $(\mathrm{ft})$ \\
\hline kilometer $(\mathrm{km})$ & 0.6214 & mile (mi) \\
\hline & Gradient & \\
\hline meter per meter $(\mathrm{m} / \mathrm{m})$ & $\begin{array}{l}1.0 \\
\text { Area }\end{array}$ & foot per foot $(\mathrm{ft} / \mathrm{ft})$ \\
\hline square meter $\left(\mathrm{m}^{2}\right)$ & $\begin{array}{l}10.76 \\
\text { Volume }\end{array}$ & square foot $\left(\mathrm{ft}^{2}\right)$ \\
\hline cubic meter $\left(\mathrm{m}^{3}\right)$ & $\begin{array}{l}35.31 \\
\text { Flow }\end{array}$ & cubic foot $\left(\mathrm{ft}^{3}\right)$ \\
\hline meter per day $(\mathrm{m} / \mathrm{d})$ & 3.281 & foot per day $(\mathrm{ft} / \mathrm{d})$ \\
\hline cubic meter per second $\left(\mathrm{m}^{3} / \mathrm{s}\right)$ & $\begin{array}{c}35.31 \\
\text { Specific Weight }\end{array}$ & cubic foot per second $\left(\mathrm{ft}^{3} / \mathrm{s}\right)$ \\
\hline newton per cubic meter $\left(\mathrm{N} / \mathrm{m}^{3}\right)$ & $\begin{array}{c}0.00637 \\
\text { Unit Stream Power }\end{array}$ & pound per cubic foot $\left(\mathrm{lb} / \mathrm{ft}^{3}\right)$ \\
\hline watt per square meter $\left(\mathrm{W} / \mathrm{m}^{2}\right)$ & 0.0685 & pound per second-foot $(\mathrm{lb} / \mathrm{s}-\mathrm{ft})$ \\
\hline
\end{tabular}

National Geodetic Vertical Datum of 1929 (NGVD of 1929): A geodetic datum derived from a general adjustment of the first-order level nets of both the United States and Canada, formerly called mean sea level. NGVD of 1929 is referred to as sea level in this report. 


\title{
THE REACTIVATION OF THE MANTI LANDSLIDE, UTAH
}

\author{
By Robert W. Fleming, Robert B. JOHnson, and Robert L. SChuster
}

\section{ABSTRACT}

The Manti landslide is in Manti Canyon on the west side of the Wasatch Plateau in central Utah. In early June 1974, coincident with the melting of a snowpack, a rock slump/debris flow occurred on the south rim of Manti Canyon. Part of the slumped material mixed with meltwater and mobilized into a series of debris flows that traveled down the slope a distance of as much as $1.2 \mathrm{~km}$. Most of the flows were deposited either at the base of the steep rocks of the canyon rim or at the site of an old, silted reservoir. A small part of the debrisflow deposit stopped on the head of the very large, relatively inactive Manti landslide. The upper part of the landslide began moving as cracks propagated downslope. A little more than a year later, August 1975, movement extended the full length of the old landslide, and about 19 million $\mathrm{m}^{3}$ of debris about $3 \mathrm{~km}$ long and as much as $800 \mathrm{~m}$ wide threatened to block the canyon.

The upper part of the landslide apparently had moved small amounts between 1939 and 1974. This part of the landslide, identifiable on pre-1974 aerial photographs, consisted of well-defined linears on the landslide flanks and two large internal toe bulges about $2 \mathrm{~km}$ downslope from the head.

The abrupt reactivation in 1974 proceeded quickly after the debris flows had provided a surcharge in the head and crown area. Movement propagated downslope at $4-5 \mathrm{~m} / \mathrm{h}$ for the first few days following reactivation. During 1974 , the reactivation probably encompassed all the parts of the landslide that had moved small amounts between 1939 and 1974. Movement nearly or completely stopped during the winter of 1974-75, but began again in the spring of 1975. The landslide enlarged from the flanks of the internal toe bulges to Manti Creek at a rate of $2-3 \mathrm{~m} / \mathrm{h}$. Movement stopped again during the winter of 1975-76 and began again in the spring of 1976. Thereafter, the displacements have been small compared to earlier.

The displacement rates for the landslide were variable depending on where and when they were measured. At the waterline crossing, about $500 \mathrm{~m}$ downslope from the head, the maximum rate was about $1 \mathrm{~m} / \mathrm{d}$, and the peak rate occurred within the first 30 days following reactivation. Almost a year later, during the spring of 1975 , the rates there were $0.1-0.3 \mathrm{~m} / \mathrm{d}$. By the time movement had propagated $2.5 \mathrm{~km}$ downslope to Manti Creek, more than $40 \mathrm{~m}$ of displacement had occurred at the waterline.

Cracks were first noted at Manti Creek on June 21, 1975, but movement was initially very slow there. The maximum rate of sliding of about $3.1 \mathrm{~m} / \mathrm{d}$ occurred during the period September 1-19, 1975, and the movement decreased and stopped during the winter of 1975-76. At the time the lower part of the landslide was moving rapidly, the rate farther upslope was small. The result was that the landslide changed from being in compression, which was caused by loading from
\end{abstract}

above, to being in extension, which was caused by the lower part moving faster than the upper part. One of the results of the extension was that the landslide pulled apart on a steeper segment of the slope and exposed the failure surface. Since the fall of 1975, the landslide has been separated into two independent parts. There has been no movement in the lower part, whereas movements in the upper part have continued at a rate of a few meters per year.

Although the landslide is $6.5 \mathrm{~km}$ from the nearest permanent dwelling, it cost nearly $\$ 2$ million in actual damages and in preparation for a major disaster that did not occur. The waterline for the city of Manti was replaced and a well was drilled to provide an emergency water supply.

\section{INTRODUCTION}

Large inactive landslides are a common feature in much of the Western United States. Some of these landslides are large enough to be shown on the geologic maps of entire States at scales of 1:500,000 or larger (Tweto, 1979; Love and Christiansen, 1985). In Colorado, an inventory of landslides by Colton and others (1976) revealed that more than 8 percent of the State is composed of landslide debris of different types. Yet, despite the widespread presence of large inactive landslides, there are few published studies of reactivation and (or) movement of these enormous masses (for example, Crandell and Varnes, 1961; Vonder Linden, 1972).

Prior to the spring of 1974, the Manti landslide in central Utah was just another of these very large inactive landslides. In the spring of 1974, movement of a smaller landslide, upslope from the Manti landslide, triggered a reactivation of movement. The Manti landslide was reactivated from head to toe for a length of about $3 \mathrm{~km}$ on an average slope of $8^{\circ}$.

The U.S. Forest Service obtained nine sets of lowaltitude aerial photography of the landslide between 1974 and 1979. Several of the sets of photographs were taken during periods of very active movement when the landslide was enlarging from head to toe. This 
photography provides a basis for understanding how the landslide became active and the way it enlarged.

\section{ACKNOWLEDGMENTS}

We express our appreciation to the U.S. Forest Service and the Utah Geological and Mineral Survey for making unique photographs and records available for this investigation. Richard Allred and Ben Black, District Rangers for the Sanpete District of the MantiLaSal National Forest, shared observations and were very helpful in solving various logistical problems. Earl Olson, Regional Geologist for the Forest Service in Ogden, freely shared his extensive data and observations. Mr. Olson's detailed measurements of movements were essential to the reconstruction of the movement history.

\section{GEOLOGIC AND GEOGRAPHIC SETTING}

The Manti landslide is on the west flank of the Wasatch Plateau, the northernmost of Utah's high plateaus, and is situated in about the middle of the State. The plateau is a major topographic divide between the Colorado River and the Great Basin, and forms a gradational structural boundary between typical Basin and Range structure to the west and the structural plateaus to the east. The Wasatch Plateau trends generally north-south, and east- and westtrending creeks have incised canyons into the plateau flanks. The east-trending canyons are much longer than their west-trending counterparts and have been extensively glaciated in their upper parts. The west-trending canyons, of which Manti Canyon is typical, are probably unglaciated and, by virtue of their shorter lengths, have somewhat greater topographic relief. The crest of the Wasatch Plateau ranges from 3,000 to $3,300 \mathrm{~m}$ in altitude, and the major valleys to the east and west (Castle Valley and Sanpete Valley) are between 1,500 and $1,800 \mathrm{~m}$. Thus, the relief of the plateau is about $1,500 \mathrm{~m}$.

Manti Canyon is located in about the middle part of the Wasatch Plateau. The altitude of the upper or east end of the canyon is about $3,170 \mathrm{~m}$, and at the city of Manti at the canyon mouth, the altitude is about $1,770 \mathrm{~m}$. The canyon drains an area of about $88 \mathrm{~km}^{2}$. Figure 1 shows the location of the Manti landslide relative to other geographic features.

The drainage basin for Manti Canyon is crudely rectangular in shape, with a maximum width of $7.1 \mathrm{~km}$ and a length of $15.3 \mathrm{~km}$. The canyon narrows abruptly near its mouth to a width of less than $800 \mathrm{~m}$.
From the mouth of the canyon to about $8 \mathrm{~km}$ upstream, Manti Creek occupies an asymmetrical V-shaped canyon. Farther upstream, Manti Creek branches into several smaller tributaries and the drainage pattern is dendritic. In the lower, V-shaped part of the canyon, the north-facing slopes are longer and gentler than the south-facing slopes. In the upper part of the canyon, the slopes are more symmetrical, and steepness is controlled more by lithology than by slope aspect.

\section{BEDROCK GEOLOGY}

Only two bedrock formations are exposed in Manti Canyon, the North Horn Formation of Late Cretaceous and Paleocene age and the Flagstaff Member of the Green River Formation of Paleocene and Eocene age. The stratigraphy of both units has been described by Washburn (1948), Spieker (1946), Robinson (1971), and Fouch (1976); it is briefly summarized here. Almost $300 \mathrm{~m}$ of a total thickness of about $730 \mathrm{~m}$ of the North Horn Formation is exposed in Manti Canyon. The best exposures are along the south-facing side. Most northfacing slopes are covered with unconsolidated debris, particularly landslide deposits. The exposed portion of the formation consists of varicolored, yellow, red, and gray shale and sandstone underlying limestone and shale of the Flagstaff Member.

The lithology of the North Horn Formation is typical of fluvial and lacustrine deposits and, consequently, varies drastically over short distances. The various lithologies within the formation have not been correlated. Washburn (1948) measured two sections of the North Horn Formation in Manti Canyon and reported that, in the nearly continuous exposures on the south-facing slope of the canyon, none of the exposed beds persists laterally with consistent lithology for more than several tens of meters. In other parts of the canyon, local beds of massive sandstone do persist for several hundred meters. One measured section of $127 \mathrm{~m}$, which was described by Washburn (1948) as typical of the lithology in the western part of the canyon, contained 50 percent sandstone, 33 percent shale, 9 percent conglomerate or conglomeratic sandstone, and 8 percent limestone. A second section of $296 \mathrm{~m}$, typical of the eastern part of the canyon, contained 75 percent shale, 21 percent sandstone, 3 percent conglomerate, and 1 percent limestone.

The contact between the North Horn Formation and the overlying Flagstaff Member is gradational in the western part of the canyon and abrupt at the eastern end of the canyon. For mapping purposes, Washburn (1948) defined the upper limit of the North Horn Formation to include beds containing more than a trace of clastic grains. 


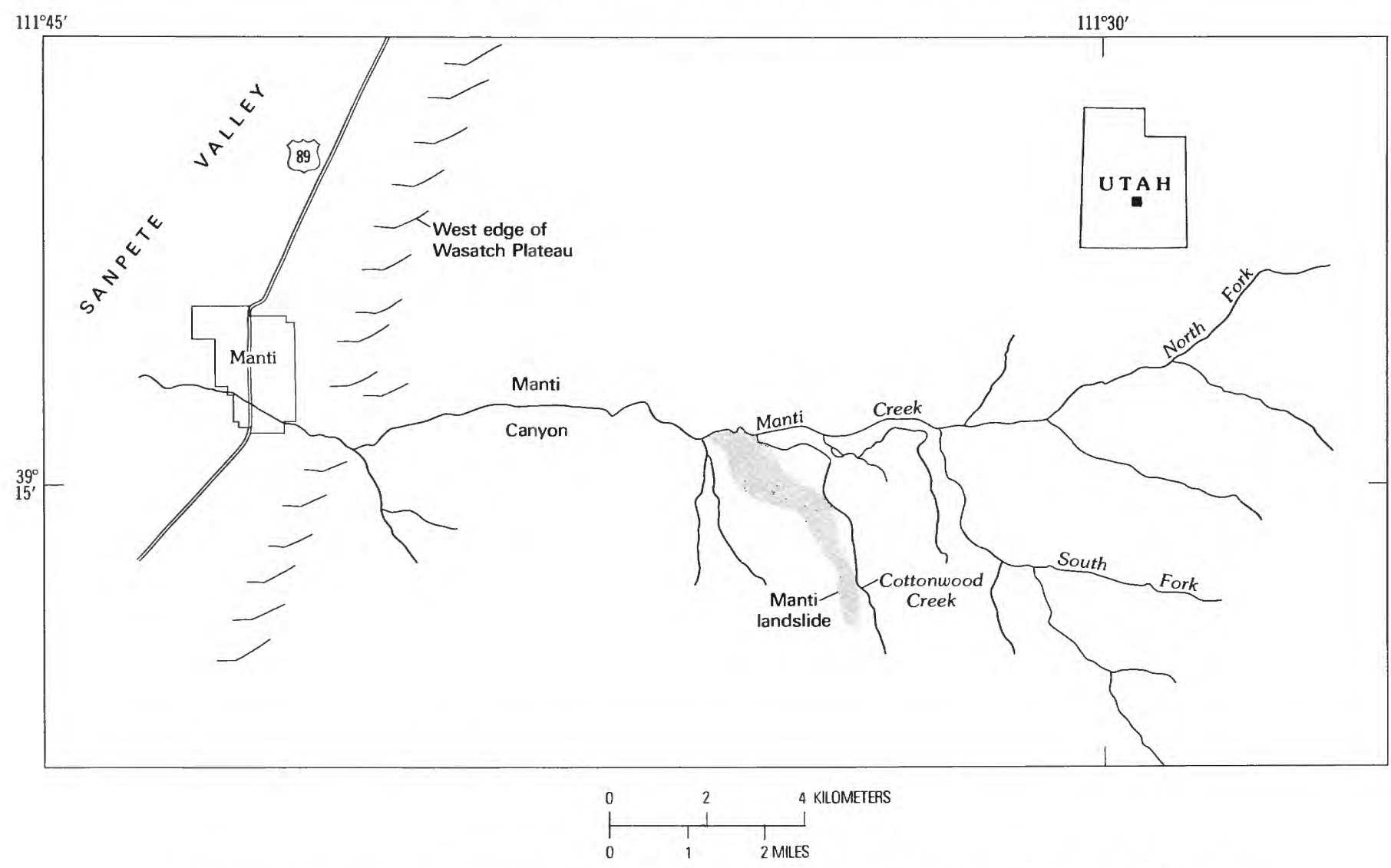

FIGURE 1.-Location of the Manti landslide, the drainage basin of Manti Creek, and the city of Manti.

The overlying Flagstaff Member of the Green River Formation is a tan and gray to blue, freshwater limestone with interbedded shale and minor amounts of sandstone and chert. About $210 \mathrm{~m}$ of its maximum reported thickness of $460 \mathrm{~m}$ (Robinson, 1971) are exposed in Manti Canyon. The Flagstaff is resistant to erosion; its position at the top of the local section produces a rim of near-vertical cliffs around much of the canyon.

A 40-m section in the Flagstaff Member was measured on the north-facing canyon rim above the Manti landslide area. The section appeared to be representative of the materials in the canyon rim and consisted of 59 percent limestone and 41 percent shale interbeds. The thickest limestone unit was $1 \mathrm{~m}$, and the thickest section of shale was $1.7 \mathrm{~m}$.

\section{GEOLOGIC STRUCTURE}

The principal structural feature in Manti Canyon is the Wasatch monocline. The monocline trends northeast across Manti Canyon and exhibits about $1,130 \mathrm{~m}$ of flexural separation between the crest of the Wasatch Plateau and the canyon mouth (Robinson, 1971). The dip of the Flagstaff Member changes from horizontal on the plateau to more than $40^{\circ}$ toward the northwest at the canyon mouth. The monoclinal arch contains a series of antithetic faults which roughly parallel the strike of the monocline. The faults dip steeply toward the east, with a normal sense of displacement in all cases except one. In the upper part of the canyon, at the west edge of horizontal beds of Flagstaff, a graben has formed. The graben, termed the "shoulder graben" by Washburn (1948), has an estimated displacement of $230 \mathrm{~m}$. Figure 2 shows views of the shoulder graben and antithetic faults exposed in the south-facing slope of Manti Canyon.

\section{LANDSLIDE DEPOSITS}

Deposits from various types of slope movements are widespread throughout the Wasatch Plateau, particularly in the canyons draining the west side. Extensive landslide debris is also found outside the canyons along the margin of the west side of the Wasatch Plateau at the edge of the Sanpete Valley. Large landslides $\left(10^{5}-10^{7} \mathrm{~m}^{3}\right)$ have developed on dip slopes of the bedrock and have slid out onto the east side of the valley. One of these, about $4.8 \mathrm{~km}$ northeast of the city of 

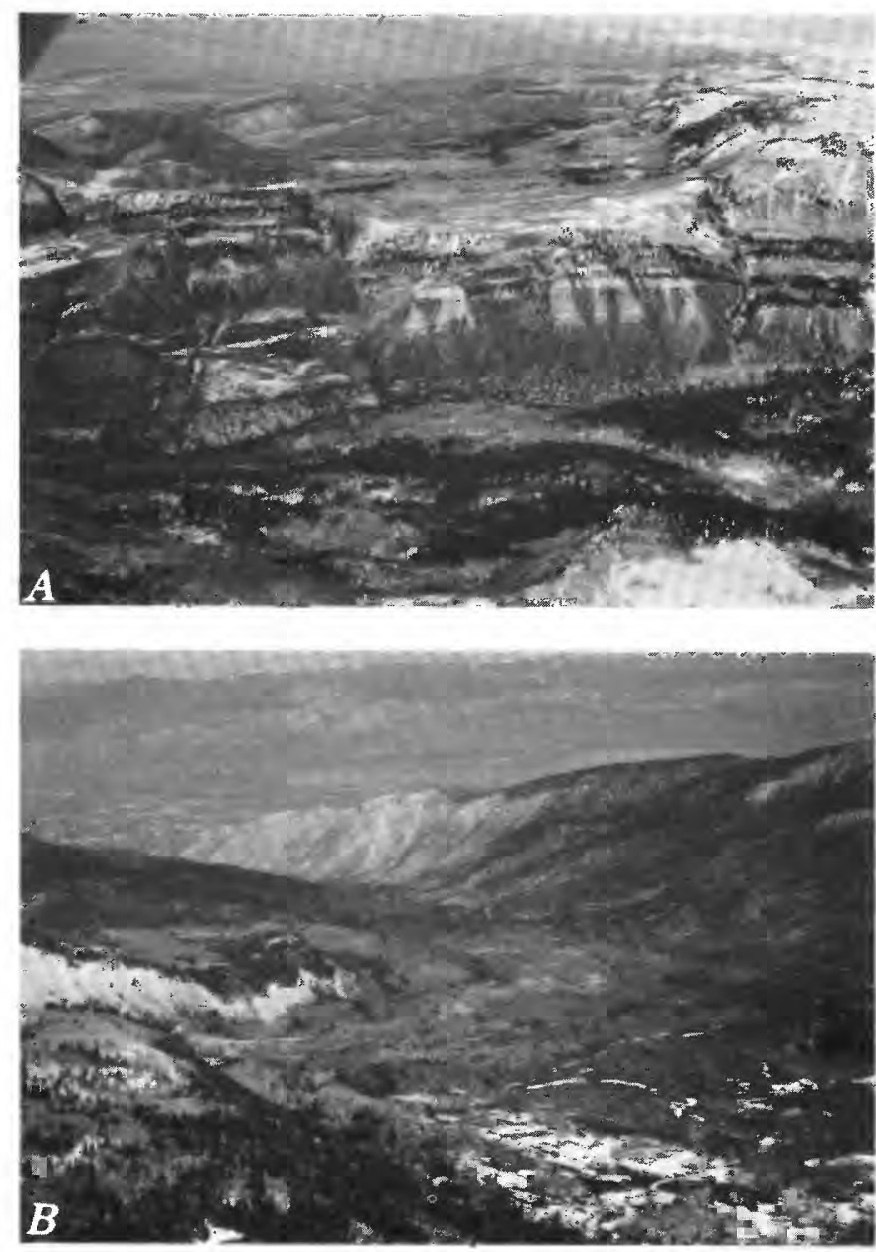

Figure 2.-Oblique aerial photographs of a portion of Manti Canyon showing two views of the Wasatch monocline. $A$, View looking north shows the "shoulder graben" which separates flat-lying rocks on the crest of the plateau from dipping rocks of the monocline. $B$, View to the west shows the monocline dipping northwest. Antithetic faults occur in the notches in the ridge line across the upper middle part of the photograph. The Manti landslide is in the lower middle part of the photograph; the topographic reentrant containing the slump/debris complex is out of the view to the left. (Photographs were taken in June 1983.)

Manti, occupies an area of about $4.5 \mathrm{~km}^{2}$ including scar and deposit. The leading edge of the deposit has encroached onto about $1,650 \mathrm{~m}$ of the eastern side of the Sanpete Valley.

Shroder (1971) compiled data on about 600 landslides in Utah and reported that the High Plateaus section (which includes the Wasatch Plateau) contains the second highest proportion of landslides in the State. He showed locations for 30 of these landslides and described the Rattlesnake Hill landslide in the Wasatch Plateau.

Godfrey (1972) completed a reconnaissance study of landslides in the Manti-LaSal National Forest, which includes Manti Canyon. Rather than mapping individual landslides, Godfrey prepared land-stability maps that subdivided the terrain into four zones of differing relative stabilities. Zone 1 contains areas of actively moving landslides and of similar bedrock formation, climate, slope, and aspect. Zone 2 contains dormant or fossil landslides and areas underlain by the same bedrock as zone 1 but with "more favorable slope, aspect, or climate" (p. 19). Zones 3 and 4 are underlain by more stable bedrock and are not generally susceptible to landsliding. About 70 percent of Manti Canyon was mapped by Godfrey (1972) as zone 1 or 2 .

Using high-altitude aerial photographs, Olson (1977) prepared an inventory of large landslides, both active and inactive, in Manti Canyon. Only the large landslides could be identified because of the scale of the photography. Nonetheless, Olson (1977) recognized about $15.9 \mathrm{~km}^{2}$ of landslide deposits from 11 separate landslides constituting about 18 percent of the total area of the Manti Canyon watershed. Five of these landslides involve both bedrock and surficial deposits and are in contact with a fault either in the crown area or along a flank.

The lower portions of most canyons on the west side of the Wasatch Plateau are choked with debris-flow deposits that extend from the debris fan at the canyon mouth upstream for 5-6 km. According to Wallace (1977), the lower part of Manti Canyon contains about $7.8 \mathrm{~km}^{2}$ of debris-flow deposits. Small slope failures involving only surficial materials are also common throughout the canyon. Thus, the aggregate area of slope-failure deposits is about one-third of the total area of Manti Canyon.

\section{PRECIPITATION}

Precipitation on and along the flanks of the Wasatch Plateau is strongly controlled by topographic relief. Figure 3 shows average precipitation for five stations as a function of altitude and distance from the mouth of Manti Canyon. Data for four of the stations are projected from Ephraim Canyon (the next canyon north of Manti Canyon). Altitudes of the head and toe of the Manti landslide are also shown in figure 3 . The average precipitation varies by a factor of nearly three over a distance of slightly more than $16 \mathrm{~km}$ between the city of Manti and the Alpine Meadows station near the top of the Wasatch Plateau. The projected distance of this precipitation change is only about $11 \mathrm{~km}$.

The average annual precipitation at the head and toe of the landslide is about 750 and $500 \mathrm{~mm}$, respectively. Precipitation during the year of the landslide reactivation, 1974, and earlier was about normal. If excess 


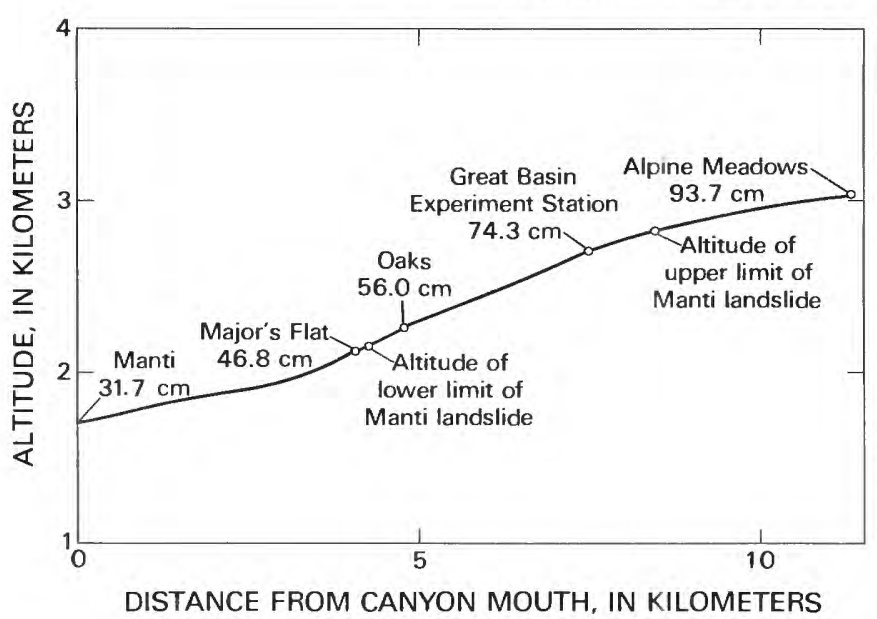

FIgURE 3.-Average precipitation as a function of altitude and distance from canyon mouth for four stations in Ephraim Canyon (10 km northeast of the Manti landslide) and one station at Manti. Data from Ephraim Canyon have been projected to a profile drawn up Manti Canyon. Data for Manti courtesy of Leslie J. Anderson, Manti, Utah. Data for Ephraim Canyon from U.S. Department of Commerce (NOAA).

moisture triggered the landslide movement, it was through an interaction of snowpack and temperature that produced abnormal amounts of water in a short time. Precipitation for the months of NovemberJanuary was 190 percent of normal and probably was preserved as snowpack. However, precipitation for the months of February-May was only 58 percent of normal. The precipitation data do not provide a compelling explanation for the initiation of the landslide.

\section{TRIGGERING CONDITIONS AND THE INITIATION OF MOVEMENT}

\section{SLUMP/DEBRIS-FLOW COMPLEX}

A complex slump/debris flow originating in the canyon rim, above the crown of the Manti landslide, was the trigger for reactivation of the Manti landslide. Plate 1 is a map showing features of the reactivated Manti landslide and the outline of the slump/debris-flow deposit. Photographs on plate 1 show the slump/debris flow from different angles. The planimetric map was produced from U.S. Forest Service photography of June 21,1979 , utilizing a PG-2 stereoplotter.

Much of the information for the first few days of slump/debris-flow activity was obtained from descriptions, measurements, and photographs provided by the U.S. Forest Service. First indications of instability were noted by two Manti city officials who reported the slumps and debris-flow deposits to the U.S. Forest Service on June 6, 1974 (Allred, 1974). The site was visited on June 7 by Forest Service and city personnel, and Allred (1974) reported the presence of the slumps and debris-flow deposits. On that date, these deposits apparently already covered about the same areas as outlined on plate 1 .

The slumps and debris flows coincided with melting of the snowpack during the first week of June. There was practically no further movement during the remainder of 1974; a few minor debris flows have occurred in subsequent years during melting in the spring. The first overflight of the slump/debris-flow area on June 15 revealed many patches of snow in the trees at the head of the Manti landslide. Photographs taken of the area of slumps in mid-June 1974 show considerable snow remaining (Allred, 1974).

The slumping occurred above the crown of the Manti landslide in a large topographic reentrant that is coincident with a fault zone. Three distinct faults occupy the zone, herein called the eastern, interior, and western faults (pl. 1). The faults, which are vertical and strike about N. $15^{\circ}-20^{\circ}$ E., have produced a zone of sheared and brecciated debris about $225 \mathrm{~m}$ wide. Displacement on opposite sides of the eastern and western faults bounding the zone has offset the Flagstaff Member, the eastern side downdropped at least $60 \mathrm{~m}$ relative to the western side.

Along the interior fault, the bedrock is intensely sheared, and silica has locally replaced limestone. Blocks of Flagstaff within the fault zone and on either side of the interior fault are rotated; to the east, the block of bedrock strikes $\mathrm{N} .2^{\circ} \mathrm{E}$. and dips $73^{\circ} \mathrm{E}$., and to the west, the block strikes N. $30^{\circ} \mathrm{W}$. and dips $16^{\circ} \mathrm{SW}$. Several springs were flowing from the base of colluvium along the interior fault, with an estimated discharge of $20 \mathrm{~L} / \mathrm{min}$, when we examined it on August 4, 1979.

The complex slump in the fault zone consists of two discrete slump blocks, one on each side of the interior fault. At their toes, the slumps were separated along the interior fault by a block of intact bedrock that did not fail (figs. 4,5 ).

The thicknesses of both slumps were estimated by a method using features that were measurable at the ground surface. Materials in the slumps were cracked, and most of the trees on the slumps were dead. However, there was very little offset on the cracks and there were no large, through-going cracks. Because of this lack of internal disruption of landslide debris and because the rotational component of movement exceeded $30^{\circ}$, the landslide was assumed to have a circular cross section.

Known geometric values for the west slump included an initial slope angle of about $30^{\circ}$, a displacement equal 


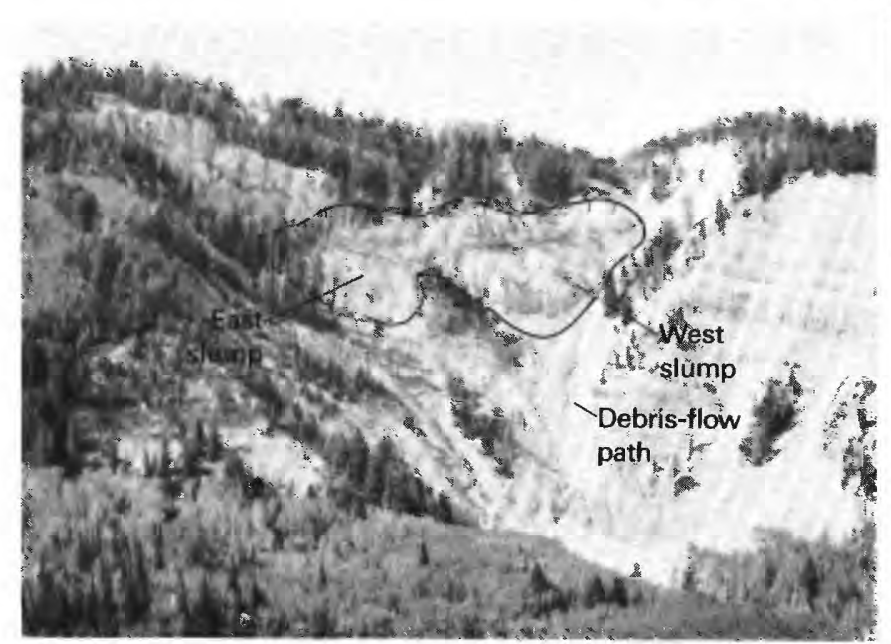

Figure 4.-Canyon rim looking south from about $1.7 \mathrm{~km}$ away at Burnt Hill. The east and west slumps are separated along the trees in the upper middle of the photograph. A smear of debris on the bedrock in the right side of the photograph marks the former passage of debris-flow episodes from the flanks and toe of the west slump.

to the scarp height of $30 \mathrm{~m}$, a length of $165 \mathrm{~m}$ and a width of $140 \mathrm{~m}$, and an amount of rotation sufficient to pond water near the head of the slump and to tilt trees up to an angle of $35^{\circ}$ off the vertical. The chord length of the circular failure, the dip of the landslide scarp, the scarp height, and a rotation of $30^{\circ}-35^{\circ}$ are boundary limitations on the maximum and average depth to the failure surface. The best fit for the failure geometry for both slumps was found by trial and error from the boundary conditions. The west slump had an average depth of $35 \mathrm{~m}$, a maximum depth of $50 \mathrm{~m}$, and a total volume of almost $800 \times 10^{3} \mathrm{~m}^{3}$.

The slump to the east of the internal fault was about $85 \mathrm{~m}$ wide, $200 \mathrm{~m}$ long, and $30 \mathrm{~m}$ thick; and it had a volume of about $500 \times 10^{3} \mathrm{~m}^{3}$. The pre-slump slope was a little steeper than $30^{\circ}$ and, in the process of failure, the eastern slump rotated back into the slope about $10^{\circ}$. The scarp height and, hence, the apparent displacement varied from a few meters to about $20 \mathrm{~m}$. The combined volume of the east and west slumps was about $1.3 \times 10^{6} \mathrm{~m}^{3}$.

Only a small part of the total volume of the slumps mobilized into debris flows (pl. 1). The mobilized debris came from the flanks and toes of the slumps in regions that had experienced large shearing strains. Evidence exists in the source areas that the flows were mobilized as a series of episodes of relatively small volume rather than a single large event. The maximum travel distance for a debris-flow episode was from the west slump to the site of Conrad Reservoir, which is almost $1200 \mathrm{~m}$. A photograph taken on June 15, 1974, of the steep face below the slumps recorded a lobe of debris flowing down the channel from the left flank of the west slump (fig. 5). Different flow episodes could not be separated in the deposits, and the sequence of debris-flow deposition is unknown.

Debris-flow deposits covered an area of about $64 \times 10^{3} \mathrm{~m}^{2}$. They were thickest at the base of the steep reentrant (fig. 5) and thinnest on the southwestern edge of the flow deposits. The maximum thickness of the deposits, estimated from seismic-refraction data, was about $6 \mathrm{~m}$. Generally, however, they were significantly thinner and were estimated to average about $1 \mathrm{~m}$ thick. Thus, the total volume of debris-flow material of about $64 \times 10^{3} \mathrm{~m}^{3}$ constituted only about 5 percent of the $1.3 \times 10^{6} \mathrm{~m}^{3}$ of the material in the complex slump. Further, only 20 percent or less of the area covered by debris flows would later become part of the reactivated Manti landslide (pl. 1). Debris-flow material that came to rest on the reactivated landslide was significantly thinner than the average thickness of the debris-flow deposits. Perhaps only 10 percent of the debris-flow deposit applied a direct surcharge to the head of the inactive Manti landslide. Patches of standing water in the crown area were evidence that the upper part of the Manti landslide was saturated at the time of failure. The rapid deposition of the debris-flow deposits created excess pore-water pressures in the saturated landslide debris. Even though a small fraction of debris-flow material actually came to rest on the landslide, the loading of material upslope and adjacent to the landslide apparently induced flow and pore-water pressure gradients into the upper part of the landslide and triggered the reactivation.

\section{THE BEGINNING OF REACTIVATION}

Between June 6 and 10, 1974, there was no indication that the landsliding would be more extensive than the slump/debris-flow event just described. However, on the evening of June 10, a Manti City official informed the U.S. Forest Service that the city waterline had been broken. The waterline crossed the Manti landslide almost $500 \mathrm{~m}$ downslope from the uppermost cracks in the head (pl. 1). The pipeline, a 25-cm (10-in.) steel pressure pipe, delivered culinary water and provided about 25 percent of Manti's electricity requirements in the form of hydroelectric power. The waterline was repaired on June 10 but had broken again on June 11 when it was inspected by U.S. Forest Service officials. A small crack in the ground near the ruptured waterline that had been noticed on June 10 was appreciably larger (fig. 6A), and downslope movement was evident (Allred, 1974). A number of Federal, State, and local officials 


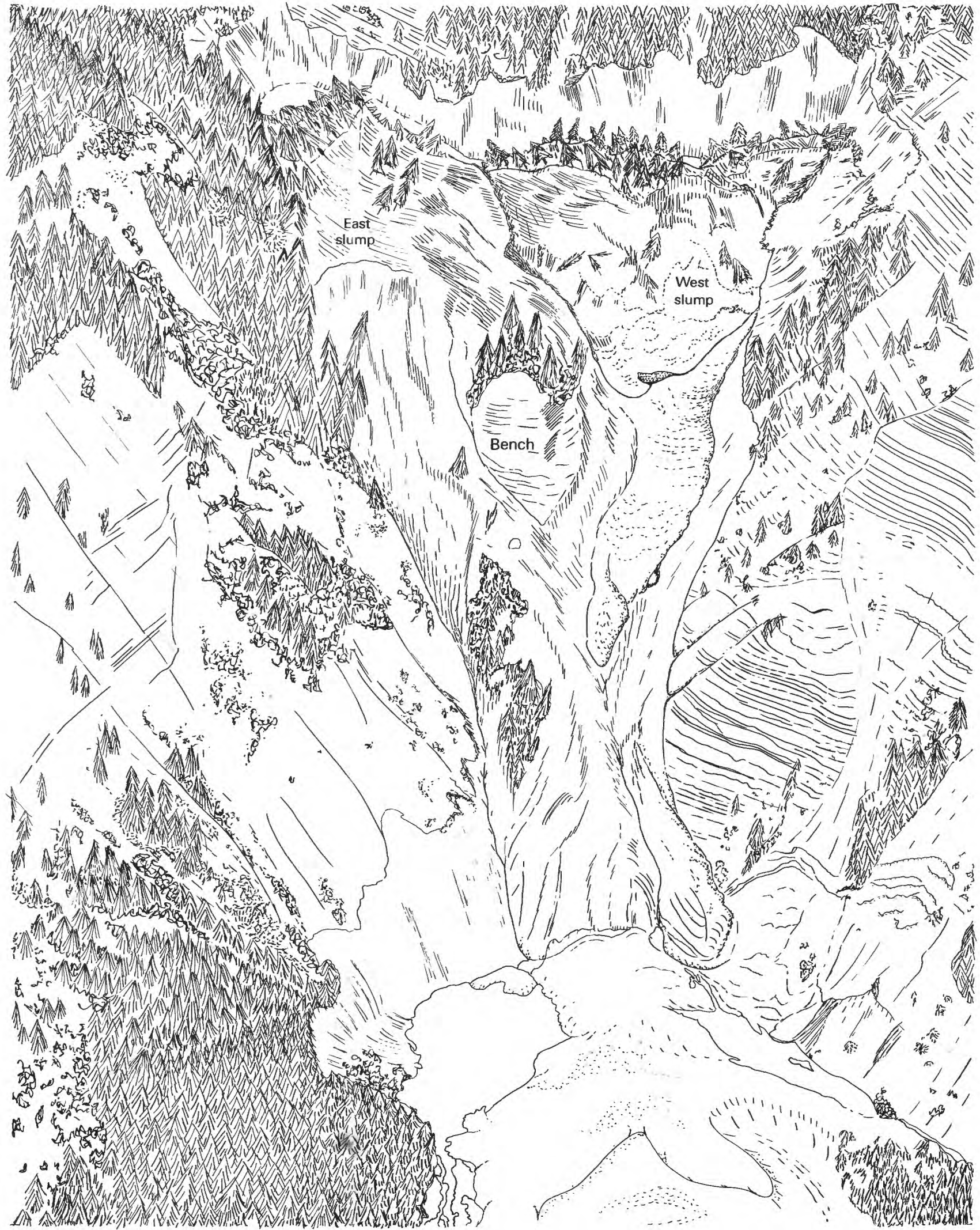

FIGURE 5.-Sketch from a U.S. Forest Service photograph of the slump/debris-flow complex on June 15, 1974. A lobe of moving debris, which had mobilized from the west slump, is shown as it reached the depositional area in the reentrant at the base of the steep slope. The uppermost crack of the reactivated Manti landslide is just outside the lower right corner of the sketch. 

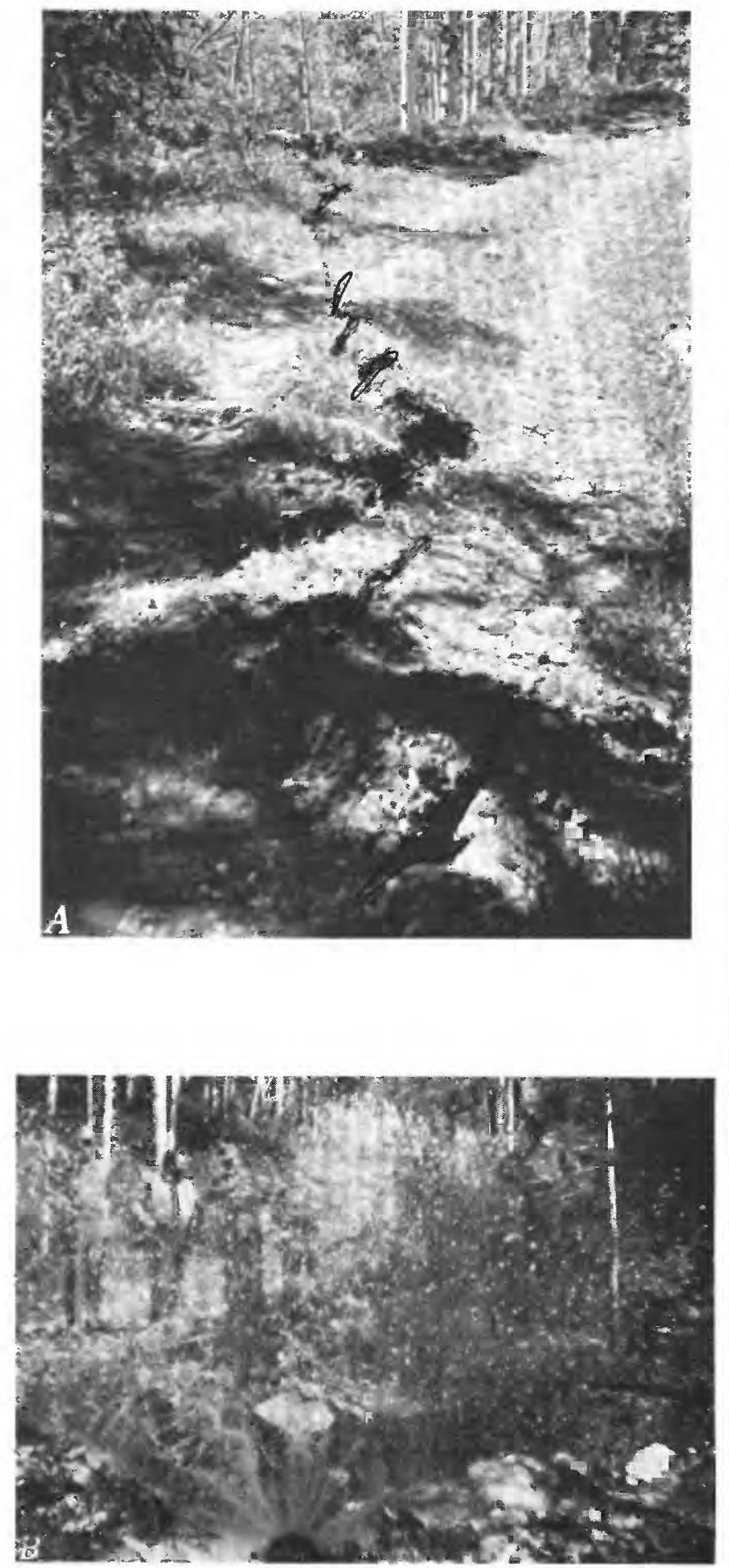

FIGURE 6.-View of initial landslide crack on the right flank of the landslide near the waterline crossing. $A$, Crack began as a series of en echelon cracks that show right-lateral shear. $B$, Waterline on the right flank of the landslide failed by pulling apart. $C$, Outside the limits of the landslide, beyond the left flank, the waterline initially failed by buckling. The waterline was later severed at the crack on the left flank of the landslide. (U.S. Forest Service photographs)

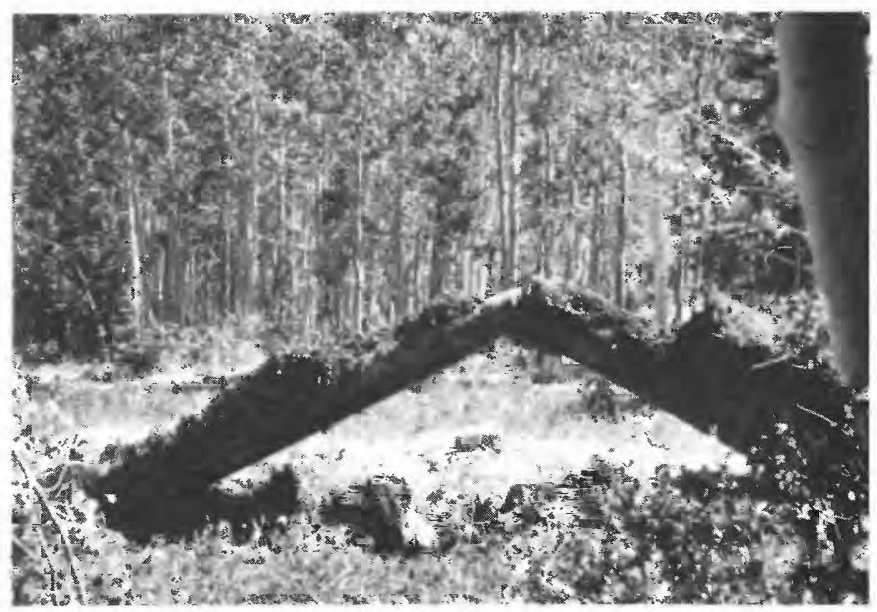

visited the site during the following few days. The first measurements of the rate of movement were made by Earl Olson, a geologist with the U.S. Forest Service, on June 13. At the waterline, the landslide was moving about $25 \mathrm{~mm} / \mathrm{h}$ on June 13 and the rate increased to $38 \mathrm{~mm} / \mathrm{h}$ on June 14.

U.S. Forest Service and Manti officials inspect the canyon regularly, and the slump/debris flow likely occurred within 24 hours of the time it was first noticed. By assuming the dates of slumping and debris-flow activity and knowing when the waterline was broken, we can estimate the average rate at which the landslide was reactivated.

The site of first cracking in the head of the landslide in response to loading by the debris-flow deposits is unknown. The simplest form of reactivation would have been for cracks to propagate downslope at a constant rate from the uppermost part of the landslide. For that case, the elapsed time between the triggering by the debris flow and the rupture of the waterline would have been between 100 and 120 hours. However, the debrisflow event could have taken place earlier than it was detected, and an unknown amount of deformation would have occurred before the waterline was broken and before a visible crack appeared at the surface. However, it is unlikely that the elapsed time between reactivation and rupture of the waterline is different from our estimate by more than a factor of two.

Given all the uncertainties, we have estimated the average rate of reactivation for the upper part of the Manti landslide to provide a basis for comparison with other landslides. To our knowledge, no rates of landslide enlargement have previously been published. In the following discussion, we term the rate at which the landslide reactivated the "enlargement rate" and the rate at which the landslide materials were sliding the "displacement rate." 
The waterline crossed the reactivated landslide almost $500 \mathrm{~m}$ downslope from the head of the landslide. If the landslide reactivation began June 6 , and if cracks started in the uppermost part of the landslide, the enlargement rate to the waterline crossing was between 4 and $5 \mathrm{~m} / \mathrm{h}$. In order for the enlargement rate to equal the displacement rate initially measured on June 13 $(25 \mathrm{~mm} / \mathrm{h})$, it would have been necessary for the slump/ debris flow to have occurred $14 \times 10^{3}$ hours (580 days) before the breakage of the pipeline. Thus, the rate of landslide enlargement must have exceeded the displacement rate by 100 to 1,000 times during the early part of the reactivation.

The waterline crosses the reactivated landslide at an oblique angle to the direction of movement (pl. 1). The waterline is about $175 \mathrm{~m}$ farther upslope on the east side of the landslide than it is on the west side, and sufficient displacement to cause the pipe to fail by pulling apart occurred on the east or upslope side (Allred, 1974). On the west side, outside the left flank of the landslide, the pipe was pushed, lifted out of the ground, and buckled prior to being severed by displacement. Figures $6 B$ and $6 C$ illustrate the different responses of the pipe to the reactivation and demonstrate that the displacements were propagated in a downslope direction. Unfortunately, we do not know the precise times that the pipe was buckled and severed on the left flank, only that it occurred at least 24 hours after rupturing on the right flank. If the enlargement rate on the left flank of the landslide was downslope at $5 \mathrm{~m} / \mathrm{h}$, the rupture of the waterline there should have occurred about $35 \mathrm{hr}$ after the rupture on the right flank.

\section{PROPAGATION OF LANDSLIDE MOVEMENT}

Information about the rates of enlargement and displacement following reactivation in early June 1974 was obtained from nine sets of aerial photographs, field measurements by Olson $(1976,1978)$, and a few field measurements by the U.S. Geological Survey. Black and white aerial photography of the landslide at a scale of $1: 15,840$ was obtained on July 10,1974 , by the Utah Geological and Mineral Survey. The U.S. Forest Service took color aerial photography at a scale of 1:6,000 in June, in August, and twice in September and November 1975, in May 1976, and in June 1979. This photography provides a basis to follow the reactivation at eight points in time over a 6-yr period (1974-79). Maps of the landslide features at the different times were prepared at a scale of $1: 4,800$ using a PG-2 stereoplotter and topographic control set by the U.S. Forest Service in October-November 1975.
The average slope of the ground surface from the head to the toe of the landslide is about $8^{\circ}$. The slope is not uniform, however, and short reaches have slope angles of about $30^{\circ}$. Williams (Chapter $\mathrm{C}$, this volume), in a study of stream-channel and pond changes on the landslide, found it necessary to separate the topography into four steeper sections (termed ramps), four flatter sections (termed benches), and a crown and toe at the top and bottom of the landslide, respectively. Two of the ramps and benches defined by Williams (Chapter C, fig. 1 , this volume) were particularly significant to the patterns of displacement and formation of cracks in the landslide. These are the Bench 1/Ramp 2 and the Bench 4/Toe reaches of the landslide that are about 700 and $2,650 \mathrm{~m}$, respectively, downslope from the uppermost cracks in the landslide. For simplicity, they are herein called the upper bench and ramp and lower bench and ramp, respectively.

The outline of the old, inactive Manti landslide is clearly visible on aerial photographs taken before 1974 . The limits of the inactive landslide surrounded a smaller area within the upper part that had sharp, well-defined boundaries, identified as boundaries of creep movement on figure 7. The boundaries terminated at two internal toes $^{1}$ within the inactive landslide and about $1.6 \mathrm{~km}$ downslope from the waterline. No cracking could be identified inside this area, but there is evidence that slow movement had occurred there in recent years. Mr. Ned Madsen, County Commissioner for Sanpete County, reported (oral commun., 1976) that, since 1939, about $3 \mathrm{~m}$ of couplings had been added to repair the waterline where it crossed the landslide. The number and dates of breakages since it was installed are unknown. Assuming that couplings were added to the waterline on both flanks of the landslide, the average rate of movement from 1939 to 1975 was somewhat less than $4 \mathrm{~cm} / \mathrm{yr}$.

The progressive reactivation and enlargement of the upper part of the landslide closely followed the welldefined boundaries within the larger, inactive landslide (fig. 8). On aerial photographs taken on July 10, 1974, the active flanks could be traced to a new internal toe about $600 \mathrm{~m}$ downslope from the waterline crossing. The formation of the internal toe within the enlarging landslide suggests that the reactivated landslide was encountering restraint farther downslope and that the rate of landslide enlargement was decreasing.

The active landslide on July 10 probably extended farther than $600 \mathrm{~m}$ downslope from the waterline, but the boundaries could not be seen on the 1:15,840-scale aerial photography. The minimum enlargement rate for the

\footnotetext{
"We use the term "internal toe" to represent a toe-like feature that is within the boundaries of a landslide. The term "toe" represents the downslope terminus of the landslide. Internal toes were formed as the landslide enlarged from top to bottom, and the internal toes were subsequently incorporated into the larger, actively moving landslide.
} 


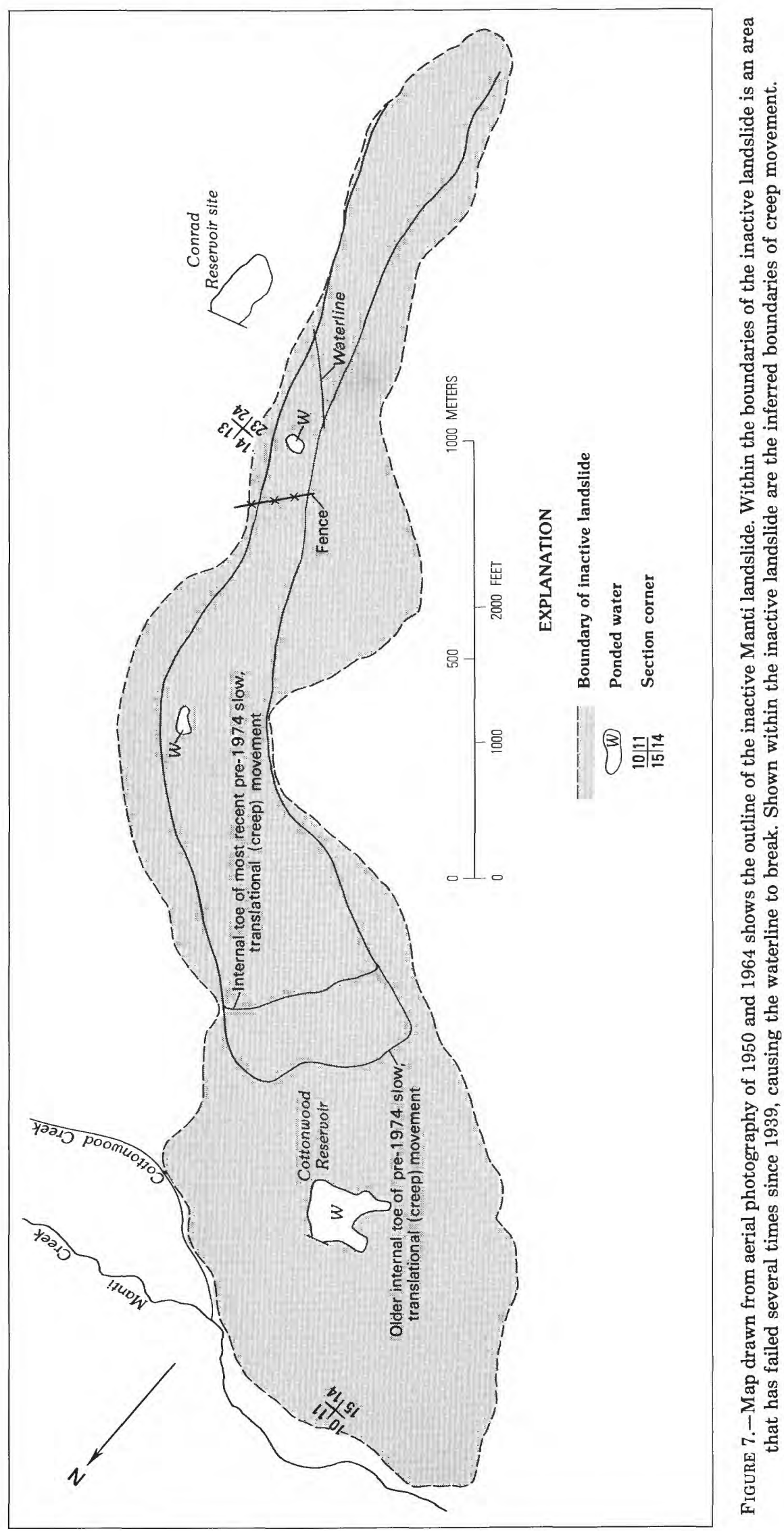




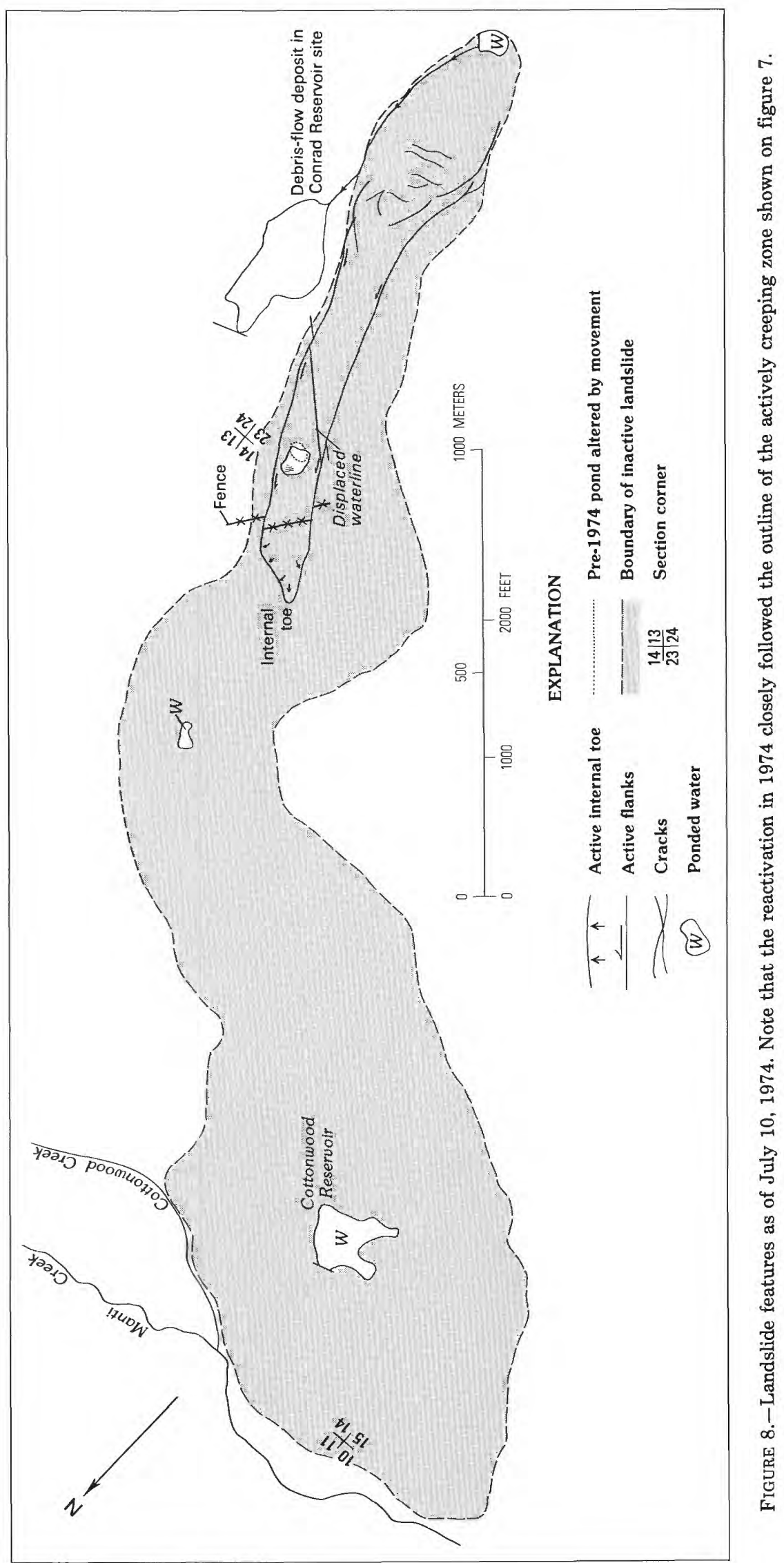


part of the landslide between the waterline on the east flank and the new internal toe shown on figure 8 was $0.8 \mathrm{~m} / \mathrm{h}$. The internal toe was well developed and clearly visible on aerial photographs of July 10, 1974. For the toe to be visible on the photographs, several meters of displacement were necessary. If the enlargement rate downslope from the waterline was the same as the $5 \mathrm{~m} / \mathrm{h}$ that we estimated for the portion of the landslide upslope from the waterline, active movement would have reached the toe on June 16 and presumably continued to propagate downslope. There is no evidence that the cracking extended beyond the toe on July 10 and the enlargement rate had slowed. Thus, the rate of enlargement of the landslide downslope from the waterline was probably somewhere between 1 and $5 \mathrm{~m} / \mathrm{hr}$.

A few measurements of displacement in 1974 were reported by Olson (1978). In the vicinity of the waterline crossing, the movement rate increased from $0.6 \mathrm{~m} / \mathrm{d}$ on June 13 to a maximum of a little more than $1 \mathrm{~m} / \mathrm{d}$ a few days later. By September, the rate had declined to $0.15 \mathrm{~m} / \mathrm{d}$.

Two things apparently influenced the displacement rate. Data we obtained later in our investigation revealed that movement of the upper part of the landslide was very sensitive to precipitation and, presumably, to precipitation-induced changes in subsurface water levels. In part, slowing of movement can be attributed to a lack of moisture during the normally dry summer months. Also, the landslide was sensitive to physical restraint. Most of the upper part of the landslide was reactivated in places of low strength that coincided with boundaries of previous movement. However, as the landslide propagated downslope, in places it was forced to create new failure surfaces. The higher strength of the debris in areas that had not failed previously led to the development of internal toes and cracks within the landslide. Work done by the landslide in forming internal toes also contributed to a reduction of displacement rate.

By the time of the next aerial photography, about 1 yr later on June 12, 1975, active movement extended downslope beyond the two pre-1974 toes shown on figure 7. The pre-1974 toes were also reactivated; movement produced discontinuous compressional ridges on the downslope sides of the toes.

Cottonwood Reservoir, located on the lower bench about $290 \mathrm{~m}$ downslope from the lower internal toe shown on figure 7, appeared unchanged and contained some water. The reservoir was normally filled in the spring by diverting water from a small stream on the east flank of the landslide. Water was not diverted into the reservoir during the spring of 1975 because of the landslide movement farther upslope. The presence of residual water in Cottonwood Reservoir is evidence for a lack of internal cracking on June 12. By the end of June, the water had drained into cracks (Olson, oral commun., 1984). A crack on the right flank of the landslide extended all the way to Cottonwood Creek at the base of the slope, and water was ponding in Cottonwood Creek. If the reactivation propagated directly downslope, cracks were likely propagating under Cottonwood Reservoir at the time of the photography on June 12.

Figure 9 is a map of landslide features as of August 24,1975 . By that date, the entire landslide, about $3 \mathrm{~km}$ long and $800 \mathrm{~m}$ wide at the toe, was moving. Cracks were well developed in the upper part of the landslide, and as much as $87 \mathrm{~m}$ of displacement had occurred on the fence line on the west flank of the landslide. At the same time, only about $12 \mathrm{~m}$ of displacement had occurred at the site of Cottonwood Reservoir; this smaller amount of displacement can be seen on figure 9 by comparing the shoreline in its pre-landslide position (dotted outline) to the shoreline on August 24 (solid outline).

The difference in displacement between the upper and lower parts of the landslide was absorbed, in some part, by three prominent internal toes that apparently formed during the progressive enlargement of the landslide. At least two of the toes were old toes reactivated from earlier (pre-1974) movement. Even though cracking had been reported by an eyewitness at Manti Creek on June 21 , the only cracks apparent in the lower part of the landslide were those in the dam of Cottonwood Reservoir; they were large enough to be seen on aerial photographs of August 24.

The lower part of the landslide has no good reference points for determination of enlargement rate. However, enough information is available to place approximate limits on the rate of reactivation. The June 21, 1975, report by Allred of cracks at Manti Creek is probably very close to the date that the surface of rupture reached that point. Allred was District Ranger for the Sanpete District of the Manti-LaSal National Forest at that time; and, through daily visits to the landslide, he had become very sensitive to changes. The only reference points for the limits of movement upslope from Manti Creek were on the photographs of July 10, 1974 (fig. 8), and June 12, 1975 (fig. 9). On July 10, the toe of active movement was about $1,900 \mathrm{~m}$ upslope from Manti Creek. Between July 10, 1974, and June 21, 1975, the average rate of enlargement was about $0.25 \mathrm{~m} / \mathrm{h}$. Apparently, during the winter of 1974, the movement of the upper part of the landslide had nearly stopped. Movement rate did not increase there again until the spring of 1975. We suspect that the rate of enlargement farther downslope also was very slow during the winter of 1974. Thus, during the spring of 1975 , when the landslide again moved more rapidly, the enlargement rate was probably much larger than the average of $0.25 \mathrm{~m} / \mathrm{h}$. 

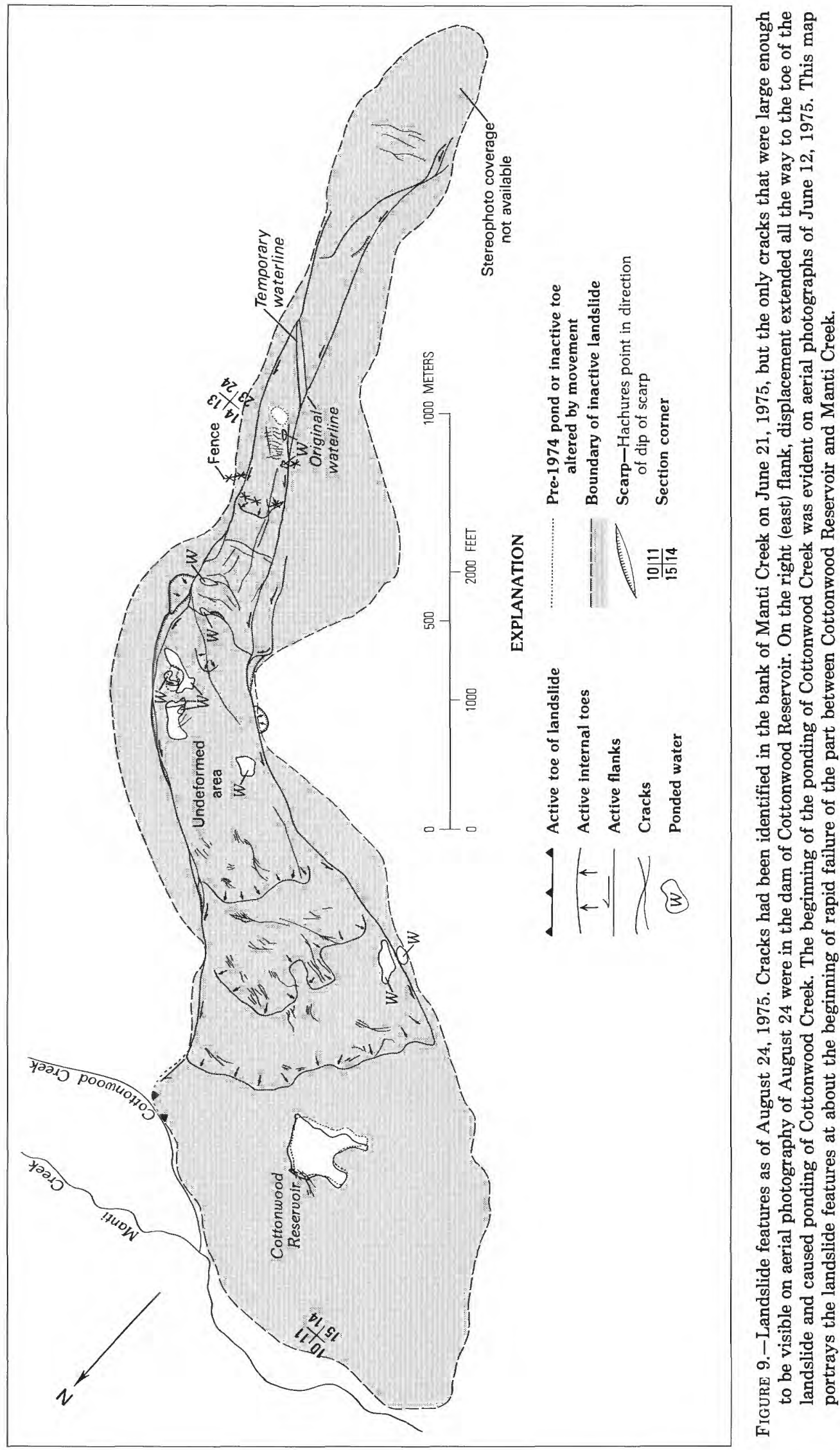
A better estimate of the enlargement was obtained by determining the distance between Manti Creek and the downslope limit of deformation visible on the June 12, 1975 , aerial photography. The downslope limit was on the east side of the landslide where a toe was forming along Cottonwood Creek. The toe is shown on figure 9, the map of features on August 24. A projection of the failure surface from the toe on the right flank passes under Cottonwood Reservoir, and the estimated enlargement rate from there to Manti Creek is about $2.2 \mathrm{~m} / \mathrm{h}$.

The estimation of enlargement rates has a number of uncertainties, and the values just listed are from measurements on the aerial photographs. The dates of the aerial photography were not optimum for computing rates because the small cracks that were formed as the landslide enlarged were not visible. The best estimates of rates occurred when there was an eyewitness observation of the extent of cracking at the waterline and at Manti Creek. The rates obtained using eyewitness reports are faster than rates obtained from measuring features on the aerial photographs. We think that the upper part of the landslide from the head to the inactive toes (fig. 7) was reactivated or enlarged at a rate of 4-5 m/h, and that the lower part of the landslide from the internal toes to Manti Creek was reactivated at a rate of $2-3 \mathrm{~m} / \mathrm{h}$. The two episodes of reactivation were separated by a period during the winter of 1975-76 when the cracks were propagating very slowly or not at all.

The landslide was about fully developed on November 6, 1975 (fig. 10). Cottonwood Reservoir had been displaced over the lower bench, with a total displacement of as much as $88 \mathrm{~m}$. The active internal toes, which had appeared in the body of the landslide as it propagated downslope, were largely obliterated; in their places, several large, uphill-facing scarps appeared.

On the upper ramp below the upper bench, the landslide separated and exposed a portion of the failure surface (see Chapter B, fig. 3 , this volume; pl. 1, fig. $D$ ). The separation had been preceded by extensional cracks at right angles to the direction of movement. By November 6,1975 , the landslide had pulled apart over a zone about $150 \mathrm{~m}$ wide.

Olson (1978) reported that movement in the toe of the landslide stopped altogether during the winter of 1975-76. The landslide had propagated to the toe on the east flank at Cottonwood Creek by June 13, 1975, and movement stopped there in December 1975. The left flank of the landslide had propagated to Manti Creek some time shortly after June 21, 1975, and displacement stopped in January or February 1976 (Olson, 1976).

Movement of the entire landslide began again in the spring of 1976. The aerial photography of May 10, 1976, revealed, however, that the new displacements were trivial compared with earlier displacements.

Displacement of the landslide in 1976 was measured at nine locations by Olson (1976). Locations of four of the measurement sites that are typical of the upper and lower part of the landslide are on figure 11, which is the map of landslide features as of May 10, 1976. Data for displacement and displacement rate at the four locations and precipitation measured at the city of Manti are shown on figure 12.

Most of the displacement in 1976 was in the upper part of the landslide (monitors 1 and 2, fig. 12). The displacement rate was a maximum in late May when readings were started. By August, movement had nearly ceased, and total displacement was about $1.6 \mathrm{~m}$.

Between May and August 1976, monitors 1 and 2 had a complex displacement record that was apparently related to precipitation. Between July 11 and July 26, the displacement rate at monitor 2 increased from $1.15 \mathrm{~cm} / \mathrm{d}$ to $1.85 \mathrm{~cm} / \mathrm{d}$. During the same period, at monitor 1 , the rate of decline of displacement was slowed.

The precipitation record for May-August 1976 for the city of Manti is also shown on figure 12. The amount of precipitation at the landslide almost certainly was greater than at Manti; but, presumably, the precipitation patterns were similar. July 1976 was the only month during the summer that the precipitation exceeded the long-term average; precipitation in July was 56 percent above normal. This compares with records for May, June, and August 1976, which were below normal 60,75 , and 72 percent, respectively (U.S. Department of Commerce, 1976). The response in rate of movement of the upper part of the landslide to precipitation between July 11 and July 26 implies both that the lag time for the water to produce an effect was short and that the rate of displacement was very sensitive to external conditions. The same cannot be said for the toe of the landslide where, on the east side, movement stopped on or before June 29, and where, on the west side, the total displacement was less than $2 \mathrm{~cm}$. The measurements at the toe on the west side of the landslide (monitor 7) showed slight changes in rate that could be attributable to precipitation. The total displacements were so small, however, that the rates are probably not significantly different.

The last set of aerial photographs of the Manti landslide was taken on June 21, 1979. The map of the slump/ debris-flow complex and the landslide, together with photographs of selected features, is shown on plate 1 . Little change occurred in the landslide between 1976 and 1979. Furthermore, the Manti landslide did not respond to the near-record precipitation when dozens of other large landslides were reactivated along the flanks of the Wasatch Plateau during the spring of 1983. 


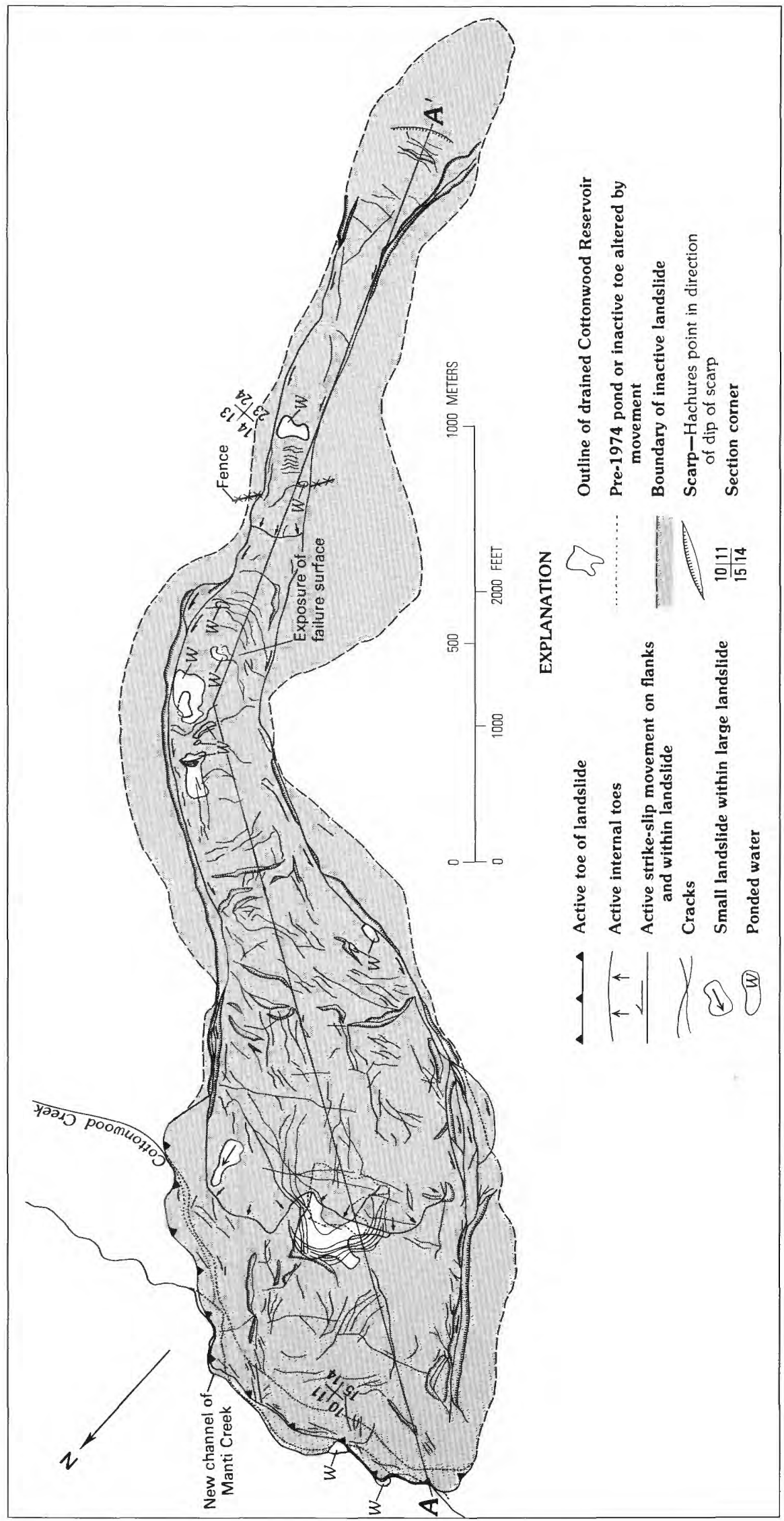

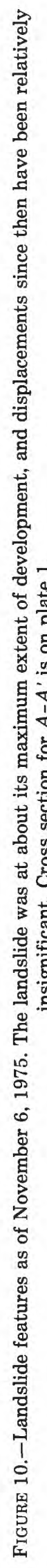




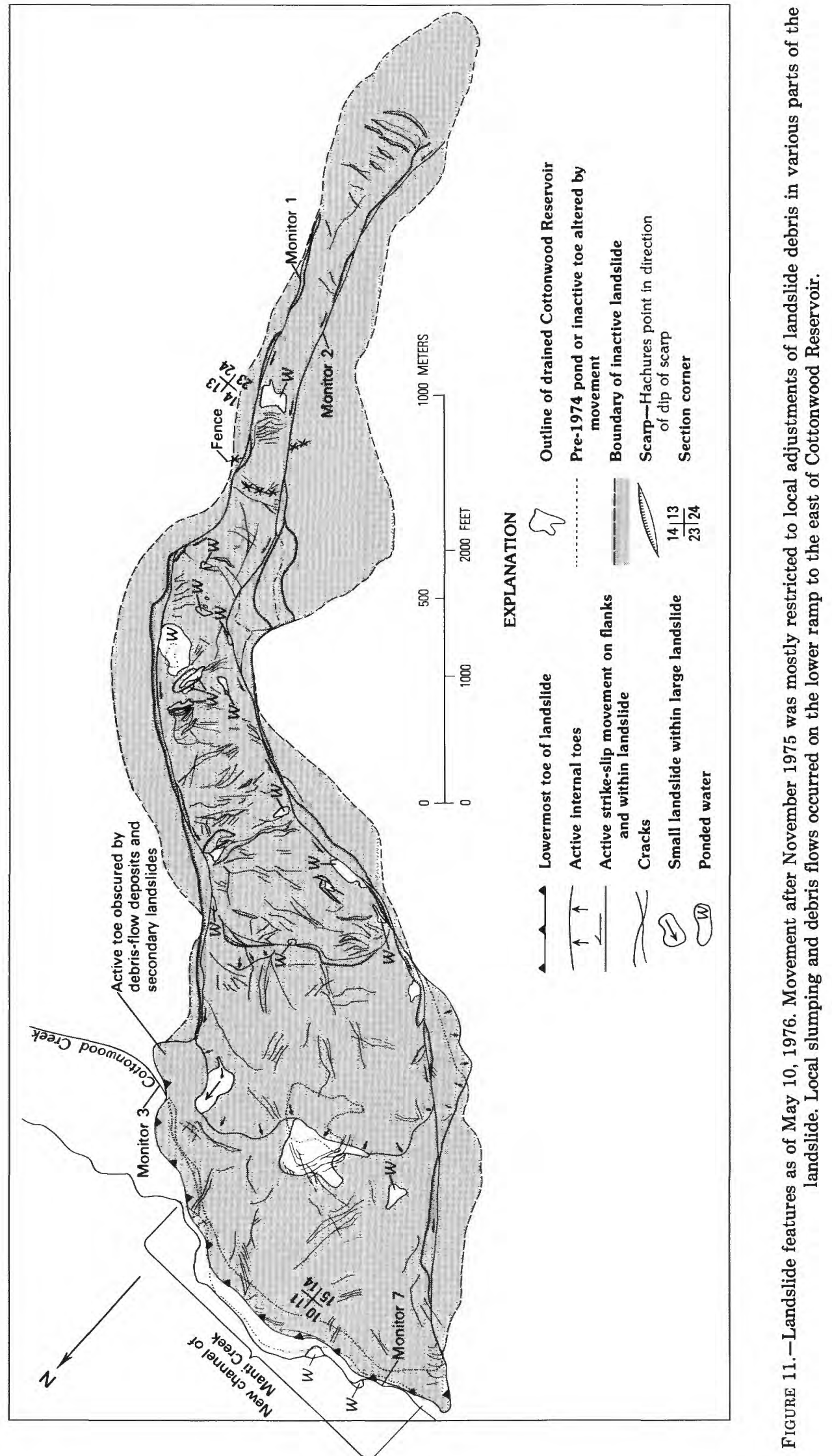




\section{SUMMARY OF DISPLACEMENT}

Measurements of displacement were made from all the sets of aerial photographs at three points and by tape measurement in the field at two of the same three points on the landslide. Results are summarized on figure 13. The offset of the fenceline was measured on both flanks of the landslide from aerial photographs and by tape, and the displacement of Cottonwood Reservoir was averaged from measurements on aerial photographs of several points on the old shoreline. The changes in slope of the displacement-time curve on figure 13 were drawn with the knowledge that the landslide moved most rapidly in the spring and slowed to a very small amount of movement in the late fall and winter. The data summarize the general movement history of the landslide through $5 \mathrm{yr}$ of activity.

The upper part of the landslide moved at its maximum rate during the first 30 days of the reactivation. On the east flank, the displacement measured by Olson (1978) was $19.8 \mathrm{~m}$, and the average rate was $0.66 \mathrm{~m} / \mathrm{d}$. During the same period, the west flank was displaced $33 \mathrm{~m}$ at an average rate of $0.83 \mathrm{~m} / \mathrm{d}$. We know from measurements by Olson (1978) that the landslide slowed to $0.15 \mathrm{~m} / \mathrm{d}$ at the waterline on the east flank in September 1974. In 1975, the displacement rates on the fenceline were largest during the interval June 12-August 14. The June 12 photography is the earliest available for 1975, and maximum rates likely occurred at or slightly before that time. On the east and west flanks, the average rates were 0.13 and $0.29 \mathrm{~m} / \mathrm{d}$, respectively. By the time displacement was noted in the toe of the landslide at Manti Creek, $44 \mathrm{~m}$ and $73 \mathrm{~m}$ of displacement had occurred on the east and west flanks at the fenceline.

The displacement of the landslide in the vicinity of Cottonwood Reservoir was more rapid than at the fenceline. On August 24, Cottonwood Reservoir had been displaced about $12 \mathrm{~m}$; on September 1, $29 \mathrm{~m}$; and on September 19, $85 \mathrm{~m}$. The average rate of displacement for the first 90 days of movement was about $1 \mathrm{~m} / \mathrm{d}$. The maximum rate between September 1 and 19 was about $3.1 \mathrm{~m} / \mathrm{d}$. During this period, the landslide separated in the area of the upper ramp, and displacements of the two parts were unrelated after the fall of 1975 . The shoreline of Cottonwood Reservoir was displaced an additional $15 \mathrm{~m}$ by May 1976, but no displacement occurred between May 1976 and June 1979.

The fenceline continued to be displaced by small amounts after May 1976, and an additional $14 \mathrm{~m}$ and $29 \mathrm{~m}$ of offset on the east and west flanks, respectively, occurred between May 1976 and June 1979. G. P. Williams (written commun., August 9, 1982) visited the landslide during the summer of 1982 and measured
$106 \mathrm{~m}$ and $202 \mathrm{~m}$ of total offset of the east and west flanks of the landslide at the fenceline. This amounts to additional displacement of $33 \mathrm{~m}$ and $63 \mathrm{~m}$ on the east and west flanks, respectively, over the 37 -mo period from June 21, 1979, to about August 1, 1982.

Farther upslope, in the vicinity of the waterline crossing, Williams measured about $4 \mathrm{~m}$ of offset of the Burnt Hill Road that occurred between "early summer" of 1980 and July 30,1982 (fig. 14). If the active movement is limited to the months of early spring, the displacements represent $2 \mathrm{yr}$ of activity. Apparently, movement of the upper part of the landslide is also slowing.

The two measurements by Williams in 1982 suggest a large displacement gradient in the upper part of the landslide. The former waterline, near the point where $5 \mathrm{~m}$ of displacement was measured between 1980 and 1982 , is only about $410 \mathrm{~m}$ upslope from the fenceline. At the fenceline, apparently 33-63 m of displacement took place between 1979 and 1982. The upper part of the landslide is unsupported at its toe on the upper ramp, and apparently the upper part of the landslide is being extended by more rapid movement near its unsupported end.

The data showing displacement versus time in figure 13 provide the basis for an explanation for differences in landslide behavior during 1974-75 and 1975-76. When reactivation began, the upper part of the landslide responded quickly, and translation of about $30 \mathrm{~m}$ occurred during the first month of activity. Downslope from the active part of the landslide, the slope was compressed. The features that were identifiable on the aerial photographs were internal toes, bulges, and other compressional features.

After the failure had propagated to the toe at Manti Creek, the compression quickly changed to extension. The rate of movement in the vicinity of Cottonwood Reservoir increased to more than $3 \mathrm{~m} / \mathrm{d}$. At the same time, the landslide at the waterline was moving less than $0.3 \mathrm{~m} / \mathrm{d}$. On the upper ramp, the landslide pulled apart and exposed the failure surface. Since fall of 1976 , the landslide has consisted of two independent parts: the upper part continues to move in response to snowmelt and precipitation; the lower part has not moved since June 1976.

\section{SOCIOECONOMIC IMPACTS OF THE REACTIVATION OF THE MANTI LANDSLIDE}

Two studies have been made of the socioeconomic impacts of the reactivation of the Manti landslide (Beacham, 1977; Fleming and Taylor, 1980).

The study by Fleming and Taylor (1980) assembled 

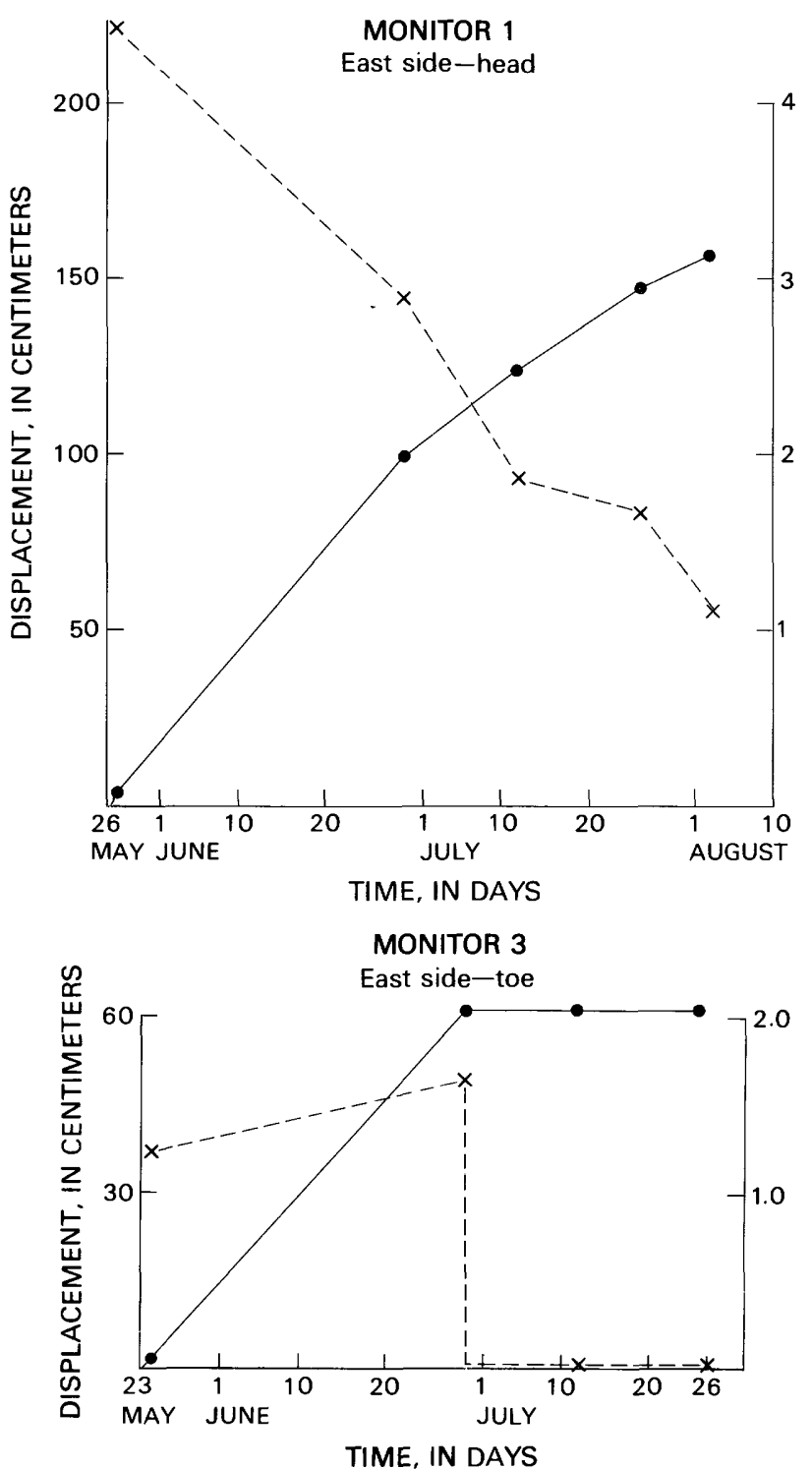

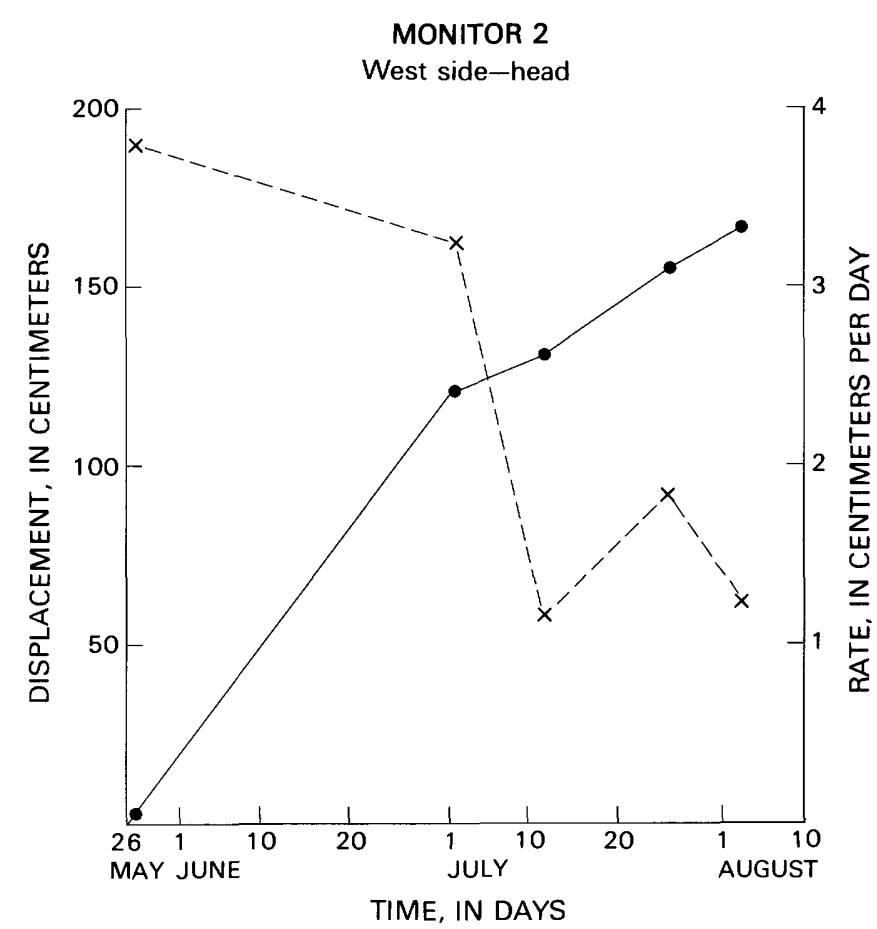

MONITOR 7

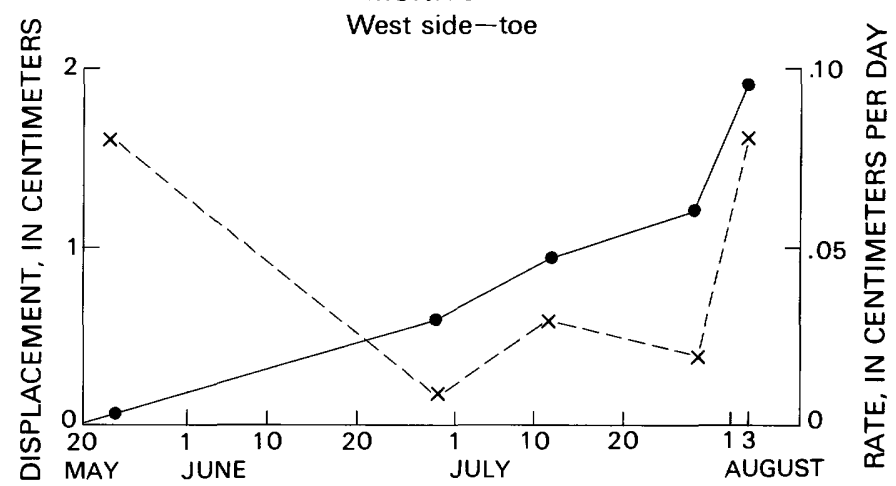

TIME, IN DAYS

$\boldsymbol{A}$

FigURE 12(above and facing page).-Displacement, displacement rate, and precipitation versus time for specific dates during the period MayAugust 1976. $A$, Displacement measurements are from four monitoring stations; these locations are shown on figure 11. Two of the stations ( 1 and 2$)$ were on the right and left flanks of the landslide near the head; the other two (3 and 7$)$ were on the right and left sides of the toe of the landslide. Displacements are shown by the solid lines; displacement rates are shown by the dashed lines. The diagrams were prepared from data reported by Olson (1976). Note the difference in plotting scale for the displacement data; displacements in the upper part of the landslide were much larger than displacements at the toe. Movement on the east side of the landslide at the toe had stopped by June 29,1976 . On the west side, total displacement was less than $2 \mathrm{~cm}$ and may have been only local movement. $B$, The data for the plot of precipitation versus time were furnished by Lee J. Anderson from a weather station in Manti, Utah. On the average (fig. 3), precipitation at the upper part of the Manti landslide is about 2.3 times that at the city of Manti.

data on the costs of landslide damage. Cost figures were obtained by interviewing individuals in the different organizations known to have expended funds (table 1) in connection with the landslide.

Although the Manti landslide is $6.5 \mathrm{~km}$ from the nearest permanent dwelling, it has proven to be a costly problem for the Manti area. The broken waterline caused loss of revenue from the hydroelectric system and has necessitated development of an emergency water supply as well as replacement of the waterline. In addition, large amounts of debris introduced into the creek by the landslide resulted in the downstream deposition of sediments in the irrigation systems and agricultural fields. Documented costs attributable to 


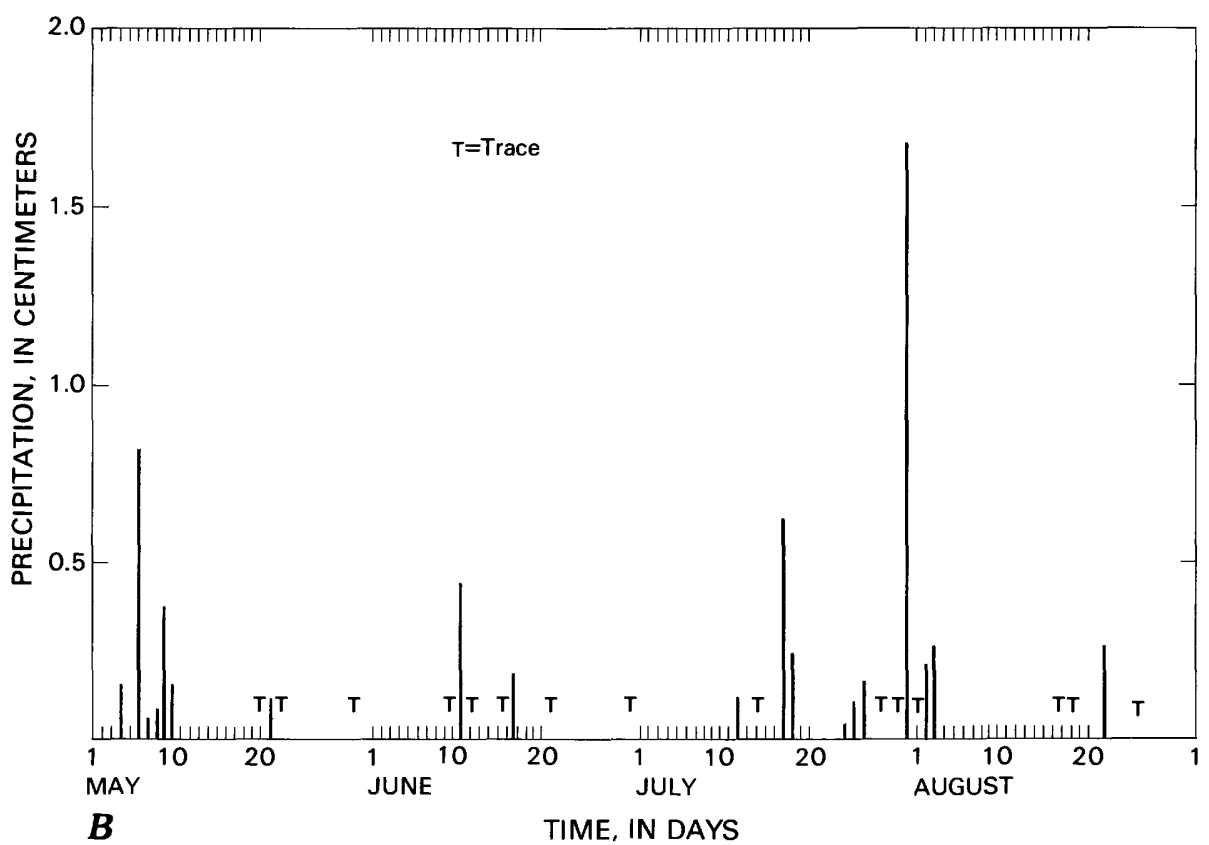

the landslide were nearly $\$ 1.8$ million by August 1976 . Approximately one-third of this cost was related to physical damage or cleanup work resulting from the earth movement. The greater portion, some $\$ 1.1$ million, was spent for investigation of the landslide and preparation for the potential disaster that did not occur.

Additional funds have been expended since August 1976, but they are small in comparison with funds spent earlier. This accounting of expenditures documents costs through August 1976; it does not, however, include some known losses that could not be monetarily evaluated and for which a cost could not be assigned. For example, on the landslide, a large number of trees were killed, Cottonwood Reservoir was destroyed, and a few animals, mostly deer, were killed. Also, damage from siltation to cropland and the irrigation system is an undetermined cost. Beacham (1977) described two unevaluated, indirect losses caused by the landslide that were not contained in Fleming and Taylor (1980). At the time of national publicity of the landslide, Manti had completed plans for an industrial park. As a direct result of the landslide, three manufacturing enterprises that were considering locating at Manti opted to locate elsewhere. Also, the unexpected costs placed unforeseen demands on the city's corporate financing, resulting in heavy long-term bonding, loss of fiscal reserves, postponement of planned improvements, and the probability of chronic long-term fiscal problems (Beacham, 1977).

The costs attributable to the Manti landslide are summarized in table 2. The amounts listed are actual expenditures, except that the figure for the State of Utah includes an estimated value of $\$ 59,000$ for service provided by the Utah National Guard. As part of their training, they donated manpower, equipment, and emergency water treatment units to the city of Manti. Including this amount seems appropriate because the services were essential and would have been required of another source if the Utah National Guard had been unable to cooperate.

The costs to the city of Manti include $\$ 67,000$ directly attributable to landslide damage. The additional $\$ 816,000$ includes funds for replacement of the waterline and valves, the drilling of a water well for an auxiliary water supply, and preventive maintenance on drainage channels. A $30.5-\mathrm{cm}$ (12-in.) waterline was installed to replace the original line of $20.3-\mathrm{cm}(8-\mathrm{in}$.$) and 25.4-\mathrm{cm}$ (10-in.) pipe, thus doubling the capability for water delivery. The installation of a new well and pump and a booster pump in the city of Manti provides a standby water system not previously available. Some part of the cost should perhaps be assigned to upgrading the water-supply facilities and not be treated as landslide damage. However, the total amount has been included because the expenditure was precipitated by the landslide. If such an inclusion results in an overstatement of costs attributable to the landslide, it is offset somewhat by the undetermined costs.

The cost to the city and, therefore, to the 1,800 residents of Manti was about $\$ 883,000$ or nearly $\$ 500$ per person. The total cost of the landslide, excluding the items that could not be defined, was about $\$ 1,800,000$ or $\$ 1,000$ per person in Manti. The costs were accrued 


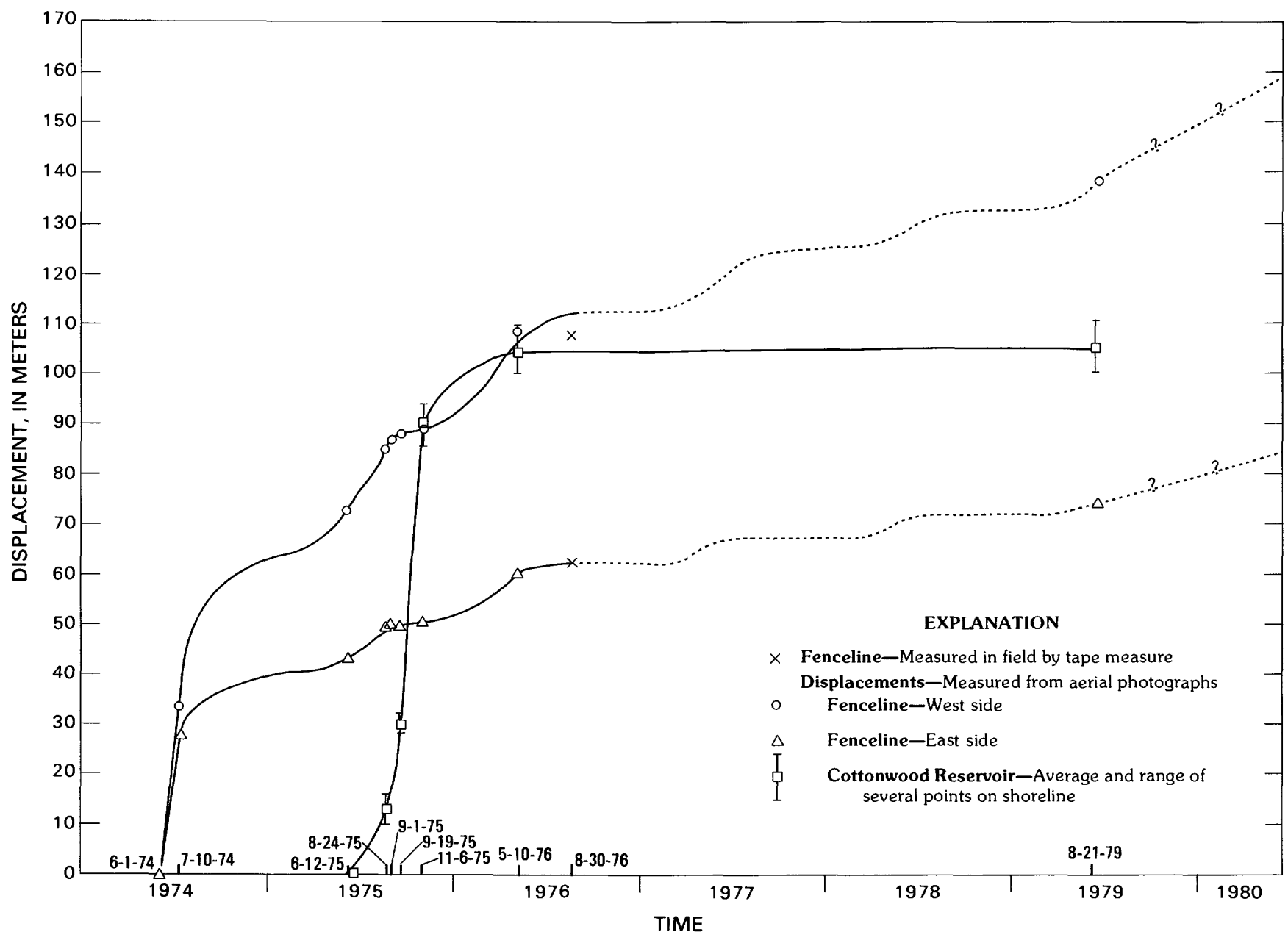

FIGURE 13.-Plot of displacement versus time for three points on the Manti landslide. Two of the points were measured from aerial photographs and checked by tape measurement. They are on the east and west flanks of the landslide at the fenceline crossing in the upper part of the landslide. The other point, measured from aerial photographs, is the average value of several measurements of displacement on the shoreline of Cottonwood Reservoir.

There is reasonably good control on movement for the period 1974-76 (solid lines). Data from Olson (1978) were used to estimate the shape of the displacement-time curves for periods when we did not have aerial photographic coverage. The dotted portions of the curves are speculative and based on the shape of the curves from earlier times. The most recent measurement, made in 1982 by G. P. Williams (written commun., 1982), indicates that the rate of movement at the fenceline crossing has increased since 1979. The lower part of the landslide has not moved significantly since May 1976.

over a 3-yr period, making the average cost $\$ 333$ per person per year.

\section{CONCLUDING REMARKS}

The Manti landslide is a good example of landslide reactivation caused by rapid loading at the head followed by downslope enlargement and propagation of cracks. In that sense, it is similar to the reactivation of the Portuguese Bend landslide of California, described by Vonder Linden (1972).
The nine sets of aerial photographs taken at different times form a good basis for monitoring changes. No substitute exists, however, for direct field measurements and observations. Without the measurements by Olson $(1977,1978)$, we could not have reconstructed the sequence of movement to the same extent. Even with the observations by Olson and the photography, several interesting features have been noted that we cannot explain. To actually have seen the landslide moving and to have monitored the evolution and destruction of pressure ridges, cracks, and other internal features would have been very useful. 


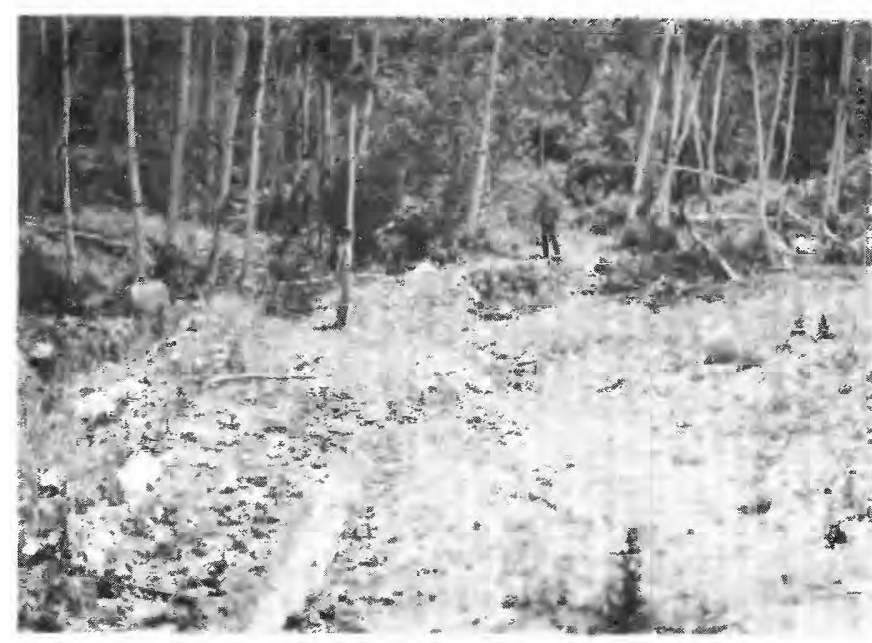

FigURE 14.-Four meters of offset of road at crossing of the east flank of the landslide near the former waterline crossing. Displacement occurred between the early summer of 1980 and July $30,1982$. Person in the background and camera align with the centerline of the road in its 1980 position. Person in middle ground is on the centerline of the displaced road. (Photograph by G. P. Williams.)

Among the unexplained and poorly understood phenomena, the following might have become clearer following field measurements:

1. Reasons for the difference in displacement on opposite flanks of the landslide at the fenceline (fig. 13) have not been discussed because of insufficient data.

2. We think that the major uphill-facing scarps within the landslide are the positions of former internal toes of movement, created when the landslide was compressive and enlarging downslope. After cracking propagated to Manti Creek, the pattern of deformation became extensional. Most of the uphill-facing scarps appeared in places that had been occupied by internal toes. However, we can identify additional uphill-facing scarps in places where internal toes were not recognized and, thus, our explanation is incomplete.

3. There were thousands of cracks in the landslide, but we know the sense of strain for only a few of them. Frequent measurements of the changes in the cracks and crack patterns could have revealed details about the depth to, and the shape of, the surface of rupture.

Aerial photographs have been shown to be useful for monitoring changes when the changes are large. The style of the reactivation, which was characterized by markedly different displacement rates in different parts of the landslide, produced several features that allowed us to examine the failure surface and to estimate the volume of the landslide.

\section{REFERENCES CITED}

Allred, C. P., 1974, Burnt Hill earth flow: Unpublished report on file at the office of the U.S. Department of Agriculture, Forest Service, Sanpete Ranger District, Manti-LaSal National Forest, Ephraim, Utah, 18 p.

Beacham, G. R., 1977, The socioeconomic effects of the Cottonwood landflow: Unpublished report of Snow College, available from Office of Community Services and Continuing Education, Snow College, Ephraim, Utah, 103 p.

Colton, R. B., Holligan, J. A., Anderson, L. W., and Patterson, P. E., 1976, Preliminary map of landslide deposits in Colorado: U.S. Geological Survey Miscellaneous Investigations Map I-964, scale 1:500,000.

Crandell, D. R., and Varnes, D. J., 1961, Movement of the Slumgullion earthflow near Lake City, Colorado: U.S. Geological Survey Professional Paper 424-B, p. B136-B139.

Fleming, R. W., and Taylor, F. A., 1980, Estimating the costs of landslide damage in the United States: U.S. Geological Survey Circular $832,21 \mathrm{p}$.

Fouch, T. D., 1976, Revision of the lower part of the Tertiary System in the central and western Uinta Basin, Utah: U.S. Geological Survey Bulletin 1405-C, 7 p.

Godfrey, A. E., 1972, A field reconnaissance of mantle instability on

TABLE 1.-Sources of information on costs of landslide damage in Manti, Utah

\begin{tabular}{lc}
\hline \multicolumn{1}{c}{ Source } & Source \\
\hline City of Manti: & Federal Government: \\
Office of the Mayor & National Weather Service \\
County of Sanpete: & Soil Conservation Service \\
Civil Defense & U.S. Army Corps of Engineers \\
Public Works Department & U.S. Forest Service \\
State of Utah: & U.S. Geological Survey \\
Office of Emergency Services & Office of Senator Moss \\
Utah Geological and Mineral & \\
Survey & \\
Utah National Guard &
\end{tabular}


TABLE 2.-Expenditures by governmental agencies on the landslide in Manti Canyon (June 1974-August 1976)

Federal Government

$\$ 769,000$

State of Utah--_-_-_-_-

County of Sanpete-

City of Manti-C-_-

Total- $\$ 1,789,000$

the Manti Division of the Manti-LaSal National Forest and on an adjacent portion of the Fishlake National Forest: Unpublished report on file at the office of the U.S. Forest Service, Ogden, Utah, 45 p., 7 pls.

Love, J. D., and Christiansen, A. C., 1985, Geologic map of Wyoming: U.S. Geological Survey Map, 3 sheets, scale 1:500,000.

Olson, E. P., 1976, Progress Report, August 25, 1976, Brief descriptions of actions related to the Cottonwood landflow near Manti, Utah: Unpublished report on file at the office of the U.S. Forest Service, Ogden, Utah, 13 p.

1977, Burnt Hill landslides, part 1 of Landslide investigation, Manti Canyon: U.S. Department of Agriculture, Forest Service, Report G-R4-77-2, May 3, 1977, 26 p.
1978, Cottonwood complex, part 2 of Landslide investigation, Manti Canyon: U.S. Department of Agriculture, Forest Service, Report G-R4-78-2, April 13, 1978, 53 p.

Robinson, G. B., Jr., 1971, Ground-water hydrology of the San Pitch River drainage basin, Sanpete County, Utah: U.S. Geological Survey Water-Supply Paper 1896, 80 p.

Shroder, J. F., 1971, Landslides of Utah: Utah Geological and Mineral Survey Bulletin 90, $51 \mathrm{p}$.

Spieker, E. M., 1946, Late Mesozoic and early Cenozoic history of central Utah: U.S. Geological Survey Professional Paper 205-D, p. 117-161.

Tweto, Ogden, 1979, Geologic map of Colorado: U.S. Geological Survey Map, 1 sheet, scale 1:500,000.

U.S. Department of Commerce, 1976, Climatological data, annual summary, Utah: U.S. Department of Commerce, National Oceanic and Atmospheric Administration, National Climatic Center, Asheville, North Carolina, p. 5.

Vonder Linden, Karl, 1972, An analysis of the Portuguese Bend landslide, Palos Verdes Hills, California: Stanford, Calif., Stanford University Ph.D. dissertation, 260 p.

Wallace, R. G., 1977, Boulder terraces and debris flows in Sixmile and Manti Canyons: Geological Society of America Abstracts with Programs, v. 9, no. 5, p. 663.

Washburn, G. R., 1948, Geology of the Manti Canyon area, central Utah: Columbus, Ohio State University M.S. thesis, 67 p. 


\section{Physical Properties and Mode of Failure of the Manti Landslide, Utah}

By ROBERT W. FLEMING, ROBERT L. SCHUSTER, and ROBERT B. JOHNSON

THE MANTI, UTAH, LANDSLIDE

U.S. GEOLOGICAL SURVEY PROFESSIONAL PAPER 1311 -B

History of displacement is used to calculate the volume of the landslide and to model the mode of reactivation 


\section{CONTENTS}

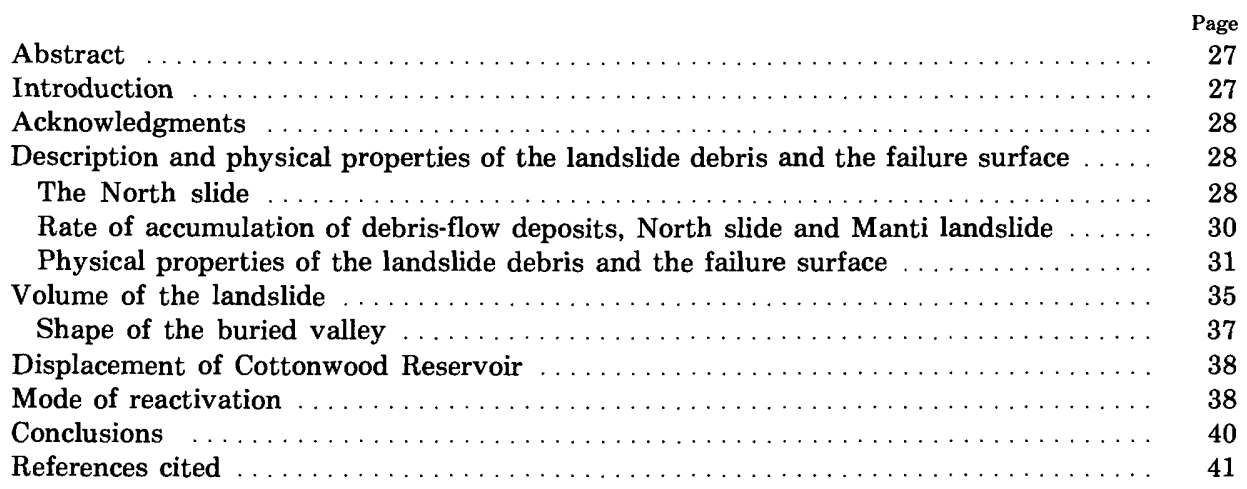

\section{ILLUSTRATIONS}

Plate 1. Map and cross section of Manti landslide ......................

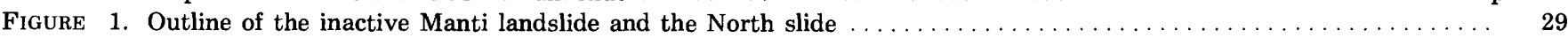

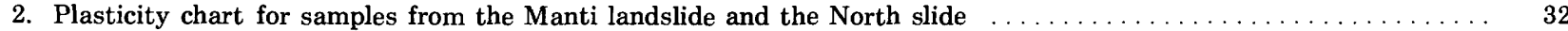

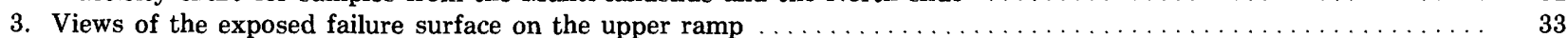

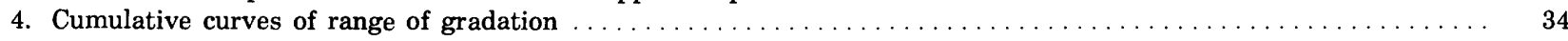

5. Sketch of two stages in the process of mechanical depletion of the coarse fraction from a failure surface $\ldots \ldots \ldots 36$

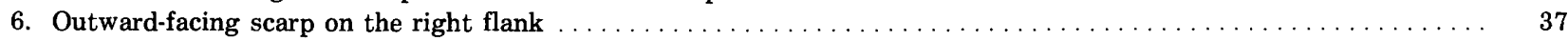

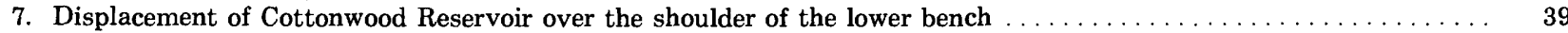

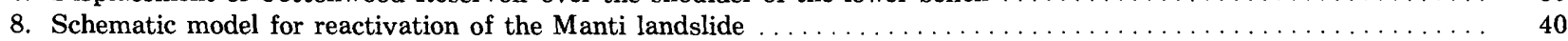

\section{TABLES}

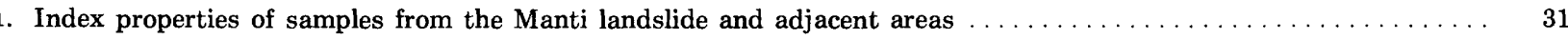

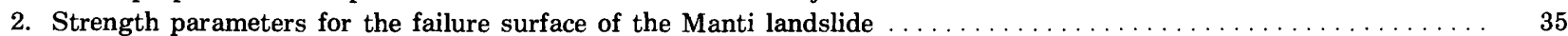





\title{
PHYSICAL PROPERTIES AND MODE OF FAILURE OF THE MANTI LANDSLIDE, UTAH
}

\author{
By Robert W. Fleming, Robert L. Schuster, and Robert B. JOHnson
}

\begin{abstract}
The Manti landslide abuts, at its toe, another large landslide called the North slide. In 1975, public officials were concerned that continued movement of the Manti landslide would trigger reactivation of the North slide. In response to this threat, four borings were placed in the North slide to obtain samples for testing and information on thickness and stability of the debris.

The materials in the North slide are virtually identical to those in the Manti landslide. Both landslides are entirely in surficial deposits that filled valleys tributary to Manti Creek. The surficial deposits are mostly accumulations of debris-flow deposits; single episodes of debris flow could be identified locally where deposits were separated by a buried soil, thin alluvial layers, a change in oxidation state, or a change in concentration of coarse fraction.

Wood fragments from a boring in the North slide provided radiocarbon dates indicating that debris flows began to accumulate as deposits in the tributary valley about 19,500 yr B.P. The long-term average rate of accumulation of debris was about $5 \times 10^{-3} \mathrm{~m} / \mathrm{yr}$.

Physical properties were measured on samples of landslide debris from the North slide and the Manti landslide and from the failure surface of the Manti landslide. Analysis of the samples revealed that the failure-surface materials had significantly different properties than the landslide debris. The differences were reflected in Atterberg limits, gradation, and strength. Average Atterberg limits of failure-surface material were LL 60 and PI 31; average Atterberg limits of the landslide debris were LL 32 and PI 14. The gradation of samples from the failure surface was 11 percent sand, 30 percent silt, and 59 percent clay. The landslide debris consisted of 53 percent gravel and sand, 24 percent silt, and 24 percent clay. A comparison of cumulative curves of gradation showed that the principal difference between the failure surface and the landslide debris was that the coarse fraction was depleted from the failure surface. Apparently, during displacement, the sand-size and larger fragments were rotated out of the failure zone. A few direct shear tests on remolded samples indicated that the effective residual strength on the failure surface was $11^{\circ}-12^{\circ}$. The effective peak angle of internal friction of the landslide debris is probably in the range of $28^{\circ}-32^{\circ}$; the amount of cohesion is undetermined.

The depth to the failure surface of the Manti landslide was known for a few points on the landslide. The landslide generally became thicker downslope, and large displacements resulted in scarps on the flanks of the landslide where thinner debris was translated to the former positions of thicker debris. The depth to the failure surface at three points, the amount of displacement, and the scarp heights
\end{abstract}

were used to compute the volume of the landslide. The pre-failure volume of the landslide was about $18.5 \times 10^{6} \mathrm{~m}^{3}$. About half the volume, $8.7 \times 10^{6} \mathrm{~m}^{3}$, was contained in the lower part between the upslope end of Cottonwood Reservoir and Manti Creek.

During the landslide movement, Cottonwood Reservoir was rotated, displaced, and strained. Comparison of the shape of the reservoir shoreline at different times, as shown on aerial photographs, revealed that the strains were not homogeneous. Qualitatively, the reservoir was stretched at right angles and compressed parallel to the displacement direction while the failure surface was propagating under the reservoir. After the failure surface reached Manti Creek, the strains reversed and the reservoir was stretched parallel to the displacement direction.

The sequence and rate of reactivation (Chapter A, this volume) suggested that the movement in part occurred on a preexisting failure surface and in part created a new failure surface. A simple model for the reactivation was developed in which the upper part of the landslide was initially at residual strength. Displacement of as much as $70 \mathrm{~m}$ of the upper part of the landslide resulted in strain energy being stored in the lower part of the slide; this energy facilitated propagation of the failure surface through as yet coherent materials. The old failure surface under the lower part of the inactive Manti landslide apparently conformed to an old channel that was deeper than the modern channel of Manti Creek and, therefore, not a convenient surface for reactivation. After the new failure surface was created, the lower part of the landslide moved more rapidly than the upper part, resulting in extensional cracking and separation of the landslide into two independent parts. Subsequently, the lower part of the landslide near Cottonwood Reservoir partially separated on the lower bench, and movement was deflected toward the west flank of the landslide. By 1979, these separations had divided the Manti landslide into three independent parts. During the spring of 1983, when melting of a near-record snowpack was triggering numerous reactivations of large, old landslides on the flanks of the Wasatch Plateau, the Manti landslide was conspicuously inactive.

\section{INTRODUCTION}

The Manti landslide was reactivated in the spring of 1974 by the loading of a debris flow from the rim of Manti Canyon. Movement propagated downslope during the next 12 months such that in the summer and 
fall of 1975, a mass of debris about $3 \mathrm{~km}$ long was moving downslope at a rate of as much as $3 \mathrm{~m} / \mathrm{d}$.

Some information relevant to the Manti landslide was obtained from another landslide, called the North slide, directly across Manti Creek from the toe of the Manti landslide. Borings into the North slide produced samples for physical-property measurements and radiocarbon dating. Samples were also obtained of the failure surface of the Manti landslide where differences in displacement rates caused the landslide to pull apart.

The sequence of reactivation of the Manti landslide allowed study of some aspects of landsliding that are rarely amenable to analysis. The style of movement and several radiocarbon dates provided information on the shape of the failure surface and the early history of the landslide. Large displacements created scarps on the flanks of the landslide that were useful in estimating the volume of the landslide. And, finally, the sequence of the reactivation provided a basis to propose a simple mechanical model for the initiation and propagation of landslide movement.

\section{ACKNOWLEDGMENTS}

Roger Nichols and George Erickson performed the laboratory tests on U.S. Geological Survey samples. Rex Baum computed the finite strains for the change in shape of Cottonwood Reservoir. Radiocarbon analyses were by Meyer Rubin, U.S. Geological Survey, and by Geochron Laboratories, Cambridge, Mass. We also express our sincere appreciation to Mr. Earl Olson of the U.S. Forest Service for freely sharing data and observations.

\section{DESCRIPTION AND PHYSICAL PROPERTIES OF THE LANDSLIDE DEBRIS AND THE FAILURE SURFACE}

\section{THE NORTH SLIDE}

At its toe along Manti Creek, the reactivated Manti landslide abuts another large, inactive landslide on the opposite side of Manti Creek called the North slide. In 1976, public officials were concerned that the rapid movement of the Manti landslide and displacement of Manti Creek would trigger a reactivation of the North slide. The realignment of the disrupted Manti City waterline was planned to cross the toe of the North slide, and displacement there would again disrupt the city's water supply. The U.S. Forest Service contracted with International Engineering Co., Inc., to conduct an investigation of the North slide and evaluate its margin of stability. As part of their investigation, four borings were drilled in the landslide debris; two of these penetrated bedrock. The drilling provided samples for laboratory testing and sites for installation of inclinometer casings. Data from the borings provide some clues to the origin, age, and physical properties of the surficial materials that make up both landslides.

The locations of the North slide and the Manti landslide, together with the locations of the borings and a topographic profile, are sketched on figure 1. Drill hole 1 (DH-1), near the toe of the North slide, penetrated $71 \mathrm{~m}(233 \mathrm{ft})$ and did not reach bedrock. DH-2 penetrated $93 \mathrm{~m}(306 \mathrm{ft})$ of debris and $6.7 \mathrm{~m}(22 \mathrm{ft})$ of bedrock. DH-3 penetrated $102 \mathrm{~m}$ (334 ft) of debris and $4.9 \mathrm{~m}$ (16 ft) of bedrock, and DH-4 did not reach bedrock in $46 \mathrm{~m}(150 \mathrm{ft})$.

The landslide debris obtained from all the borings was a dense, clayey, sandy gravel varying in color from light to dark gray, as well as exhibiting various shades of brown to red produced by oxidation. Some of the darker horizons appeared to be poorly developed buried soils. The gravel-size and larger rock fragments were angular to subround fragments of sandstone and limestone, which were locally derived from the North Horn Formation and the Flagstaff Member of the Green River Formation. The cored debris was, overall, very poorly sorted except for a few rare circumstances in which a section of the core contained a thin layer of well-sorted sand or clay. The only other internal differences in a section of core were varying concentrations of rock fragments, color changes, and the presence of scattered zones of slickensides.

These textural and gradational characteristics are typical of debris-flow deposits. The varying concentrations of rock fragments, thin alluvial beds, and poorly developed buried soils indicate, at the very least, that the materials were deposited episodically. The gradation of the debris is consistent with that of debris-flow deposits from other areas (Rodine, 1974) and from the canyon rim above the Manti landslide in 1974.

Another indication of a debris-flow origin of the deposits is the amount of coarse fraction in the core samples. Concentrations of gravel-size and larger rock fragments over a 1-m interval varied from a few percent to more than 80 percent. One interval (33-39 m) in DH-3 was essentially all cobble- to boulder-size rock fragments in a matrix of sandy clay.

The color changes in the core samples were of no value in separating the debris-flow episodes. Some changes were abrupt and could, perhaps, represent debris-flow boundaries; but, more commonly, the color changes were gradational. Dark-colored zones that appeared to be buried soils did not provide sufficient organic 


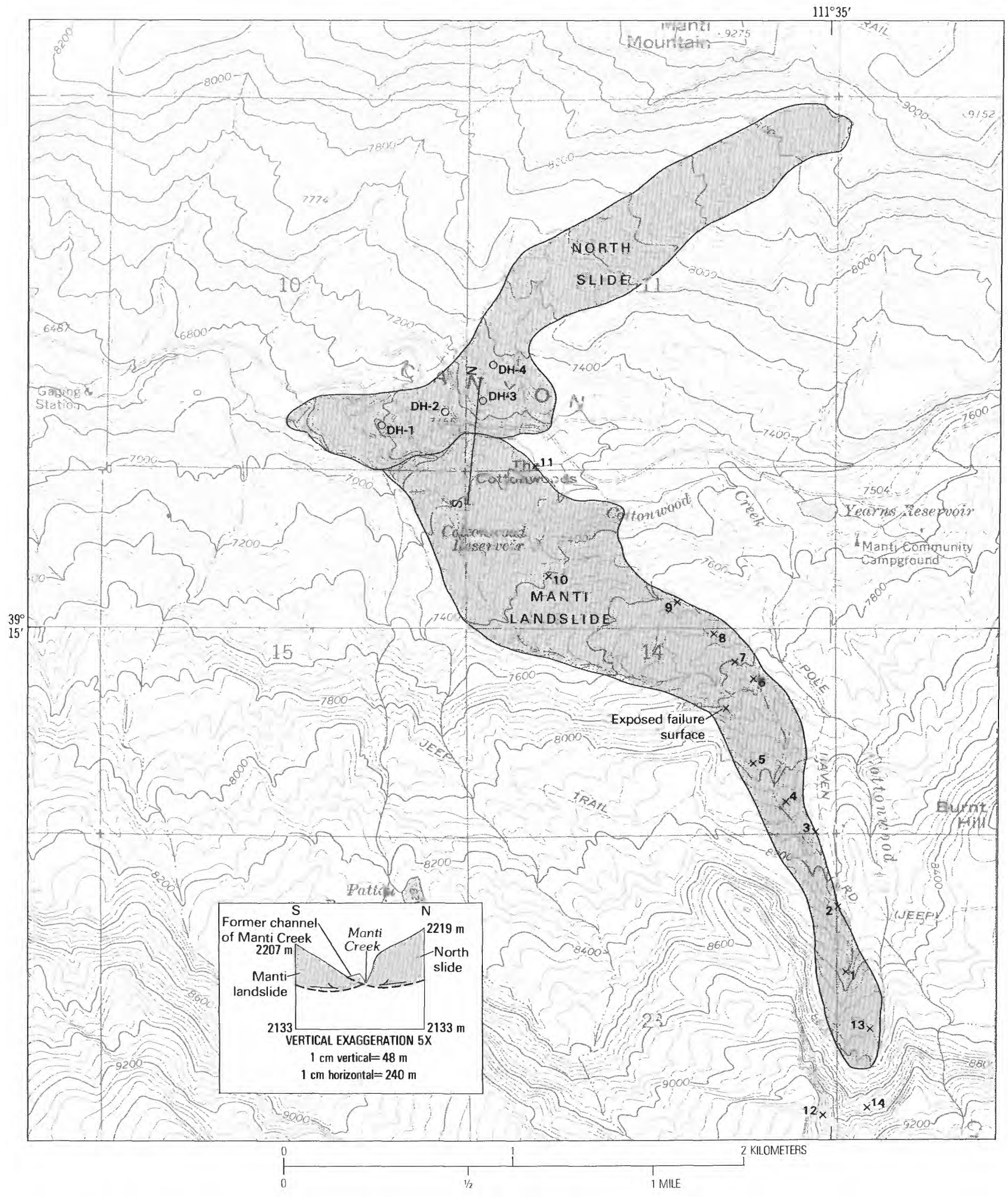

Figure 1.-Outline of the inactive Manti landslide and the North slide showing drill-hole locations on the North slide and sample locations on the Manti landslide. Inset cross section (S-N) shows the pre-landslide profile across Manti Creek. Refer to figure 1 (Chapter A, this volume) for a location map of the Manti landslide. 
concentrates for ${ }^{14} \mathrm{C}$ dating (Meyer Rubin, written commun., 1981). The presence of several oxidized zones as much as $6 \mathrm{~m}$ thick, together with buried organic layers within the thick section of debris, supports the idea of rapid deposition of debris separated by relatively long intervals of time.

Slickensides were present in core samples from all of the borings. Each boring contained three to five zones of slickensides that ranged from a single shiny surface to many surfaces over a cored length of $5 \mathrm{~m}$. No slickensides were found at depths shallower than $17 \mathrm{~m}$. Core recovery for the four borings averaged 72 percent, and additional sheared zones likely exist, but were not identified. Because of incomplete core recovery, no generalizations have been made about continuity between the slickenside zones found in the different boreholes. There was a thick zone of slickensides near the bedrock contact at a depth of 95-100 $\mathrm{m}$ in DH-3; but the deepest slickenside in $\mathrm{DH}-2$, the other boring that reached bedrock, was $17 \mathrm{~m}$ above the bedrock. Some of the slickensides, which range in dip from $16^{\circ}$ to $80^{\circ}$, may have been produced by differential consolidation or secondary shearing related to landsliding.

Sheared zones tend to have higher water contents than adjacent, unsheared material. International Engineering Company, Inc. (1976), noted that the natural water content of material in the slickensided zones was as much as 23 percent compared to about 10 percent for unsheared debris.

Although the materials in the North slide are accumulations of debris-flow deposits, surface morphology clearly indicates that the North slide has moved by sliding. And, further, the North slide apparently moved more recently than the lower part of the Manti landslide. A remnant of the toe of the North slide (see inset cross section on fig. 1) was identifiable on the south side of Manti Creek prior to reactivation of the toe of the Manti landslide in 1975 (Olson, 1978). At the contact between the remnant toe of the North slide and the Manti landslide (about $10 \mathrm{~m}$ above Manti Creek), the former bed of Manti Creek was exposed. The deposit in the former creek bed consisted of about $0.5 \mathrm{~m}$ of well-rounded, wellsorted gravel overlying several meters of sandy silt. The fine-grained deposit is interpreted as representing deposits ponded by a blockage of Manti Creek resulting from movement of the North slide. The gravel deposits project to a local terrace upstream from the North slide and Manti landslide. The modern channel of Manti Creek cuts through the toe of the North slide.

RATE OF ACCUMULATION OF DEBRIS-FLOW DEPOSITS, NORTH SLIDE AND MANTI LANDSLIDE

Materials making up both the North slide and the Manti landslide have accumulated from multiple debris flows that have filled preexisting tributaries to Manti Creek. Except in a few isolated cases, we could not identify the boundaries of separate debris-flow episodes in the core samples. We could only distinguish separate flow episodes when exposures or core samples contained abrupt changes in the concentration of coarse debris, a poorly developed buried soil, or poorly sorted debris separated by a thin, well-sorted alluvial layer. The surface of both the North slide and the Manti landslide is irregular and appears to consist of coalescing lobes of poorly sorted debris as much as $3 \mathrm{~m}$ high. During the active movement of the Manti landslide, cross sections of the lobes were exposed by cracks and revealed that some lobes overlay buried soils.

Radiocarbon dates were obtained on five samples and provide a crude estimate of when the preexisting valley began to fill and of the rate at which debris accumulated. Fragments of carbonized organic material and buried soils were noted in cores from all the boreholes. But, unfortunately, carbon sufficient for dating was limited to wood fragments from two depths in boring DH-2. One, from a depth of $55.5-58 \mathrm{~m}$ (sampled by Earl P. Olson of the U.S. Forest Service), yielded a date of 9,540 285 ${ }^{14} \mathrm{C}$ yr B.P. The other, from a depth of $90.2-90.5 \mathrm{~m}$, yielded a date of $16,520 \pm 130{ }^{14} \mathrm{C}$ yr B.P. This second sample is particularly significant in that it is only $3 \mathrm{~m}$ above the contact with bedrock and represents a minimum date for the beginning of aggradation of debris in the preexisting valley. In the vertical section of DH-2, 33.6 m of debris were deposited (depths of 56.8 and $90.4 \mathrm{~m}$ ) in about 7,000 yr for an average aggradation rate of $4.8 \times 10^{-3} \mathrm{~m} / \mathrm{yr}$. If this aggradation rate was uniform through time, about $19,500 \mathrm{yr}$ were required to fill the preexisting valley with debris.

Three other radiocarbon dates were obtained on grab samples. A sample of wood from the south bank of Manti Creek about $400 \mathrm{~m}$ downstream from the North slide yielded a date of $10,120 \pm 120{ }^{14} \mathrm{C}$ yr B.P. The wood was about $2 \mathrm{~m}$ above the creek bed and overlain by two poorly developed buried soils and the modern soil. Two other samples of wood collected and dated by the U.S. Forest Service, each from a depth of about $1 \mathrm{~m}$, were from debris in the Manti landslide. One, from the west side of the landslide about $1 \mathrm{~km}$ downslope from the head, was dated at $2,760 \pm 120 \mathrm{yr}$ B.P. The other, from the toe of the landslide, was dated at $1,050 \pm 100$ yr B.P. (Earl P. Olson, written commun., 1977).

These data from the borings, in addition to the surface morphology of the North slide and Manti landslide, provide an indication of the origin, source, and age of the debris; but the data do not date the onset of failure by landsliding of the Manti landslide. As will be discussed later, there are indications that the Manti landslide was last active over its entire length when Manti 
Creek was flowing in a much deeper channel. However, the altitude of the channel at the time of movement of the entire landslide is unknown.

\section{PHYSICAL PROPERTIES OF THE LANDSLIDE DEBRIS AND THE FAILURE SURFACE}

Several samples from the Manti landslide and the North slide were tested for index properties including clay mineralogy, Atterberg limits, gradation, and density. Strength parameters were measured on a few undisturbed and remolded samples. Some of the data obtained by International Engineering Company, Inc. (1976), from the borings in the North slide and U.S. Forest Service measurements of physical properties have been combined with U.S. Geological Survey measurements of samples from the Manti landslide.

Samples 2 through 11, landslide debris, were taken in a systematic traverse from the head to the toe of the landslide (for locations, see fig. 1). Overall, the index properties of the landslide debris are similar throughout the surface of the landslide (table 1). Less gravel-size material and slightly lower Atterberg limits are found in the lower part of the landslide. The finer gradation and lower plasticity perhaps indicate addition of sandstone from the North Horn Formation to the landslide materials. During sampling, we noted that nearly all the gravel-size and coarser fragments between sample points 2 and 5 (fig. 1) were limestone from the Flagstaff Member. Between sample points 5 and 6 , the landslide passes over a sandstone-supported steeper slope (the upper ramp); and at sample point 6 , the coarse fraction of the debris contains a few sandstone fragments. Cottonwood Reservoir, just downslope from sample point 10 , is on a bench above a second sandstone-supported steep slope (the lower ramp). Farther down in the toe region of the landslide, sandstone fragments are about equal in abundance to limestone.

The clay mineralogy (table 1) of all the surface samples of the landslide was fairly consistent. Illite and mixed-layer clay predominated; montmorillonite was a common but subordinate mineral. The clay minerals are not uniformly distributed through the debris, however; and, locally, the "popcorn" appearance of the ground surface suggests that montmorillonite was the principal clay mineral. International Engineering Company, Inc. (1976), found that montmorillonite was the principal clay mineral at depth in all four of their borings into the North slide. We analyzed the clay mineralogy of one sample from the failure surface of the Manti landslide. Sixty percent of the clay-size fraction was composed of clay minerals consisting of 60 percent montmorillonite, 30 percent mixed-layer clay, and 10 percent kaolinite.

TABLE 1.-Index properties of samples from the Manti landslide and adjacent areas

\begin{tabular}{|c|c|c|c|c|c|c|c|c|c|c|c|c|c|}
\hline \multirow{4}{*}{$\begin{array}{c}\text { Sample } \\
\text { No. }\end{array}$} & \multicolumn{4}{|c|}{$\begin{array}{l}\text { Particle-size distribution } \\
\text { ASTM classification } \\
\text { Percent of dry soil weight }\end{array}$} & \multirow{4}{*}{$\begin{array}{l}\text { Reaction } \\
\text { with } \\
10 \text { percent } \\
\text { HCl }\end{array}$} & \multirow{2}{*}{\multicolumn{3}{|c|}{$\begin{array}{c}\text { Atterberg } \\
\text { limits }\end{array}$}} & \multirow{2}{*}{\multicolumn{5}{|c|}{ Clay mineralogy 1}} \\
\hline & \multirow{2}{*}{$\begin{array}{l}\text { Grave1 } \\
(>4.76)\end{array}$} & \multirow{2}{*}{$\begin{array}{l}\text { Sand } \\
(4.76- \\
0.075) \\
\end{array}$} & \multirow{2}{*}{$\begin{array}{l}\text { Silt } \\
(0.075- \\
0.005)\end{array}$} & \multirow{2}{*}{$\begin{array}{l}\text { Clay } \\
(<0.005)\end{array}$} & & & & & & & & & \\
\hline & & & & & & $\overline{\mathrm{LL}}$ & $\mathrm{PL}$ & $\overline{P I}$ & \multirow[t]{2}{*}{ Chlorite } & \multirow[t]{2}{*}{ Kaolinite } & \multirow[t]{2}{*}{ Illite } & \multirow{2}{*}{$\begin{array}{l}\text { Montmo- } \\
\text { rillonite }\end{array}$} & \multirow{2}{*}{$\begin{array}{l}\text { Mixed } \\
\text { layer }\end{array}$} \\
\hline & & & & & & & & & & & & & \\
\hline 1 & 44 & 13 & 15 & 28 & Moderate-- & 38 & 25 & 13 & 4 & 4 & 2 & 3 & 1 \\
\hline 2 & 38 & 19 & 15 & 28 & Strong---- & 44 & 26 & 18 & 4 & 4 & 3 & 2 & 1 \\
\hline 3 & 63 & 9 & 9 & 19 & -- do---- & 45 & 27 & 18 & 4 & 3 & 1 & 3 & 2 \\
\hline 4 & 60 & 9 & 10 & 21 & $--\mathrm{do}-----$ & 45 & 26 & 19 & 4 & 4 & 2 & 3 & 1 \\
\hline 5 & 24 & 15 & 32 & 29 & $--\mathrm{do}-----$ & 25 & 16 & 9 & 4 & 3 & 2 & 4 & 2 \\
\hline 6 & 65 & 11 & 7 & 17 & -- do------ & 41 & 24 & 17 & 4 & 4 & 2 & 3 & 1 \\
\hline 7 & 19 & 13 & 28 & 40 & $\rightarrow-$ do---- & 33 & 18 & 15 & 4 & 4 & 2 & 3 & 1 \\
\hline 8 & 48 & 18 & 12 & 22 & $--\mathrm{do}-----$ & 31 & 16 & 15 & 4 & 4 & 3 & 2 & 1 \\
\hline 9 & 22 & 14 & 16 & 48 & -- do----- & 34 & 20 & 14 & 3 & 4 & 2 & 3 & 1 \\
\hline 10 & 17 & 19 & 32 & 32 & $--\mathrm{do}-----$ & 25 & 14 & 11 & 3 & 4 & 2 & 4 & 1 \\
\hline 11 & 12 & 18 & 33 & 37 & -- do------ & 32 & 17 & 15 & 4 & 3 & 3 & 3 & 1 \\
\hline 12 & 0 & 4 & 40 & 56 & --do------ & 29 & 19 & 10 & 4 & 4 & 2 & 3 & 1 \\
\hline 13 & 24 & 29 & 17 & 30 & -- do------ & 39 & 22 & 17 & 3 & 4 & 2 & 3 & 1 \\
\hline 14 & 0 & 1 & 24 & 70 & ---do----- & 46 & 27 & 19 & 4 & 4 & 2 & 3 & 1 \\
\hline
\end{tabular}

1: 40-60 percent.

2: 20-40 percent.

3: 10-20 percent.

4: Less than 10 percent. 
The remainder was clay-size fragments of quartz, calcite, and dolomite. The exchangeable cations in the clay fraction were dominated by calcium and magnesium (International Engineering Company, Inc., 1976).

The scarcity of montmorillonite in surface samples compared to deeper samples is a discrepancy that cannot be solved with existing data. Montmorillonite is present in the source materials but is a subordinate mineral there also. Samples 1, 12, 13, and 14 (table 1) were from the crown area above the Manti landslide, the shale interbeds in the Flagstaff Member, the debrisflow deposit uphill from the Manti landslide, and the fault gouge in the Flagstaff, respectively. The fault gouge and shale interbeds lacked a significant gravel and sand fraction but otherwise were similar to the surface samples of the landslide debris. Robinson (1977) noted the lack of montmorillonite near the surface and suggested that it is authigenic after illite and mixedlayer clays.

Atterberg limits, both from samples from the borings in the North slide and from surface samples of the Manti landslide, are plotted on figure 2. Liquid limits (LL) of the slide debris generally range from 18 to 45; the plasticity index (PI) ranges from 5 to 20 . Samples plot above the A-line, and the fine fraction of the debris classifies as clays of low plasticity. Three samples of debris from the borings in the North slide had liquid limits greater than 50, one of which was from a slickensided zone. Average Atterberg limits for all 48 samples of landslide debris are LL 32, PI 14.

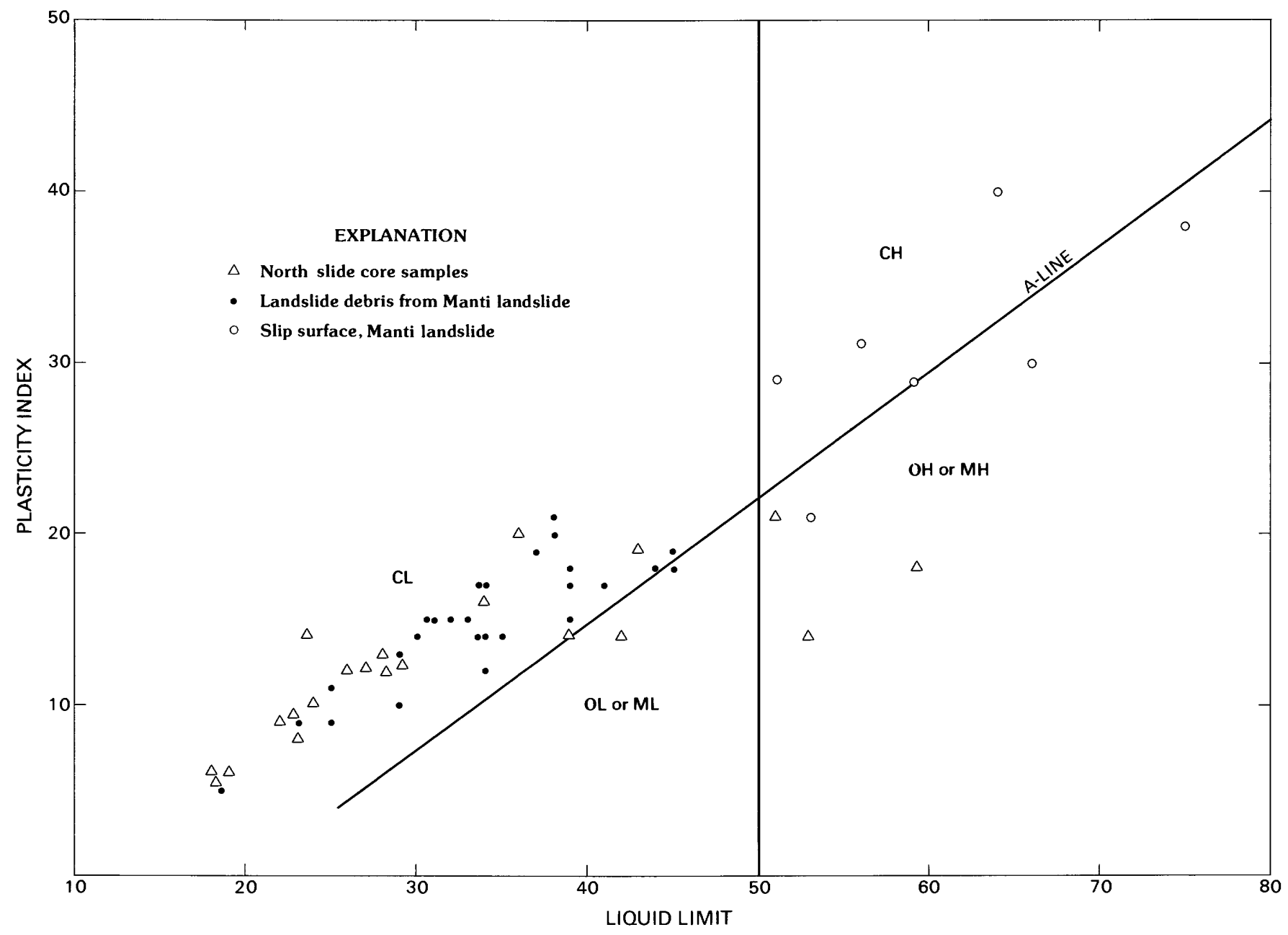

FIGURE 2.-Plasticity chart for samples from the Manti landslide and the North slide. Data for the North slide are from International Engineering Company, Inc. (1976). Definitions of symbols are as follows: $\mathrm{CH}$, inorganic clays of high plasticity; $\mathrm{OH}$ or $\mathrm{MH}$, organic silts and clays of medium to high plasticity or inorganic silts; OL or ML, organic silts and organic silt-clays of low plasticity or inorganic silts and very fine sands with slight plasticity; CL, inorganic clays of low to medium plasticity. Engineering experience has shown that samples of the same genetic soil are represented by points along a line that is roughly parallel to the A-Line. 
Atterberg limits were also obtained on samples of the failure surface of the Manti landslide, from the upper ramp where a separation in the landslide exposed about a 2,000- $\mathrm{m}^{2}$ area of the failure surface (see pl. 1; fig. 3). Atterberg limits of eight samples of the failure surface range from LL 75, PI 40 to LL 51, PI 21. Average Atterberg limits for seven samples from the failure surface are LL 60, PI 31. Thus, the difference in plasticity characteristics between the landslide debris and materials from the failure surface is striking.

Gradation was measured for 42 samples: 13 samples from the North slide and 29 samples from the Manti landslide, including 8 samples of the failure surface. The average gradation of the 34 samples of landslide debris was 52.5 percent sand and gravel, 23.5 percent silt, and 24 percent clay. The average gradation of the eight samples from the failure surface was 11 percent sand and gravel (nearly all sand), 30 percent silt, and 59 percent clay. The failure surface, where we were able to sample it, was greatly enriched in clay-size material relative to the landslide debris. In terms of average properties, the amount of clay-size material more than doubled from 24 to 57 percent. The gradation of the landslide debris, predominantly debris-flow material, compared to the failure-surface material is shown in figure 4.

Specific gravity of the solids of landslide debris was measured on 19 samples and averaged 2.65. The dry density of the landslide debris is controlled to a certain extent by the amount of coarse fraction in the sample, such that the maximum density would be $2.65 \mathrm{~g} / \mathrm{cm}^{3}$. Four samples from the borings in the North slide, from depths ranging from 27.4 to $94.5 \mathrm{~m}$, varied from 2.02 to $2.24 \mathrm{~g} / \mathrm{cm}^{3}$. Twenty-three other samples from the North slide that were taken for strength testing had an average dry density of $2.05 \mathrm{~g} / \mathrm{cm}^{3}$ (International Engineering Company, Inc., 1976).

The average of seven measurements of dry density from two block samples of the material in the failure surface of the Manti landslide was $1.60 \mathrm{~g} / \mathrm{cm}^{3}$. No measurements were made of density of the Manti landslide debris; but, because both landslides contain materials from the same source area, prefailure density should have been about the same as that of the North slide $\left(2.00-2.08 \mathrm{~g} / \mathrm{cm}^{3}\right)$. After landslide movement, cracking and deformation likely reduced the dry density to $1.60-2.00 \mathrm{~g} / \mathrm{cm}^{3}$.

In an attempt to determine the strength of the failure surface of the Manti landslide, undisturbed block samples that contained the failure surface of the Manti landslide were taken. Because the failure surface was exposed in only one relatively small area (fig. 1), the degree to which the strength measurements are representative of the entire landslide is unknown.
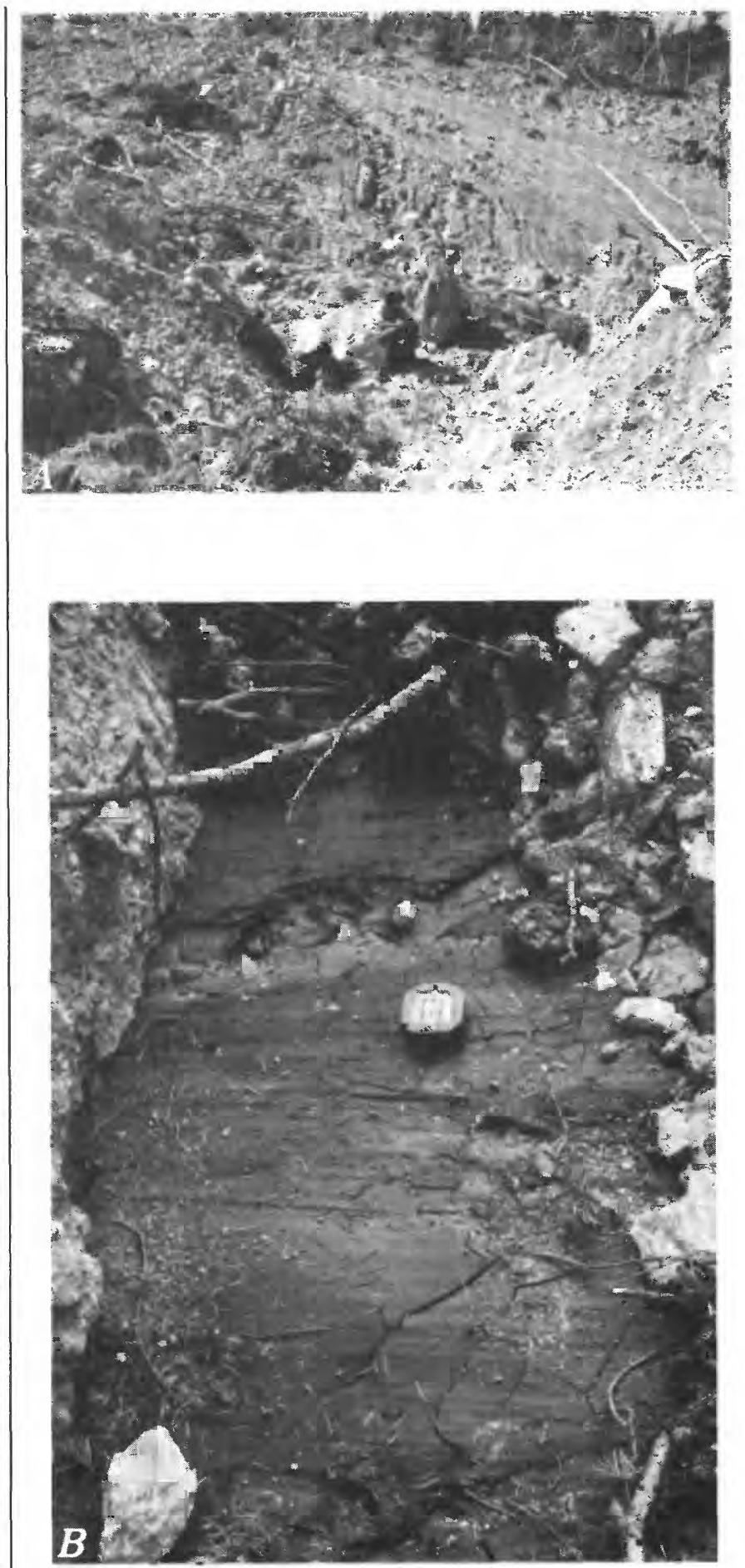

FIgURE 3.-Views of the exposed failure surface on the upper ramp. $A$, View looking south of large area of exposed, but weathered, failure surface. In lower left of the photograph, block samples containing the failure surface are being removed for testing. $B$, Closeup view of failure surface that was exposed between two large blocks of landslide debris. Note the absence of coarse material on the slip surface. Gravel-size fragments are abundant within 1-2 cm below the surface and can be seen just above and slightly left of the Brunton compass. 


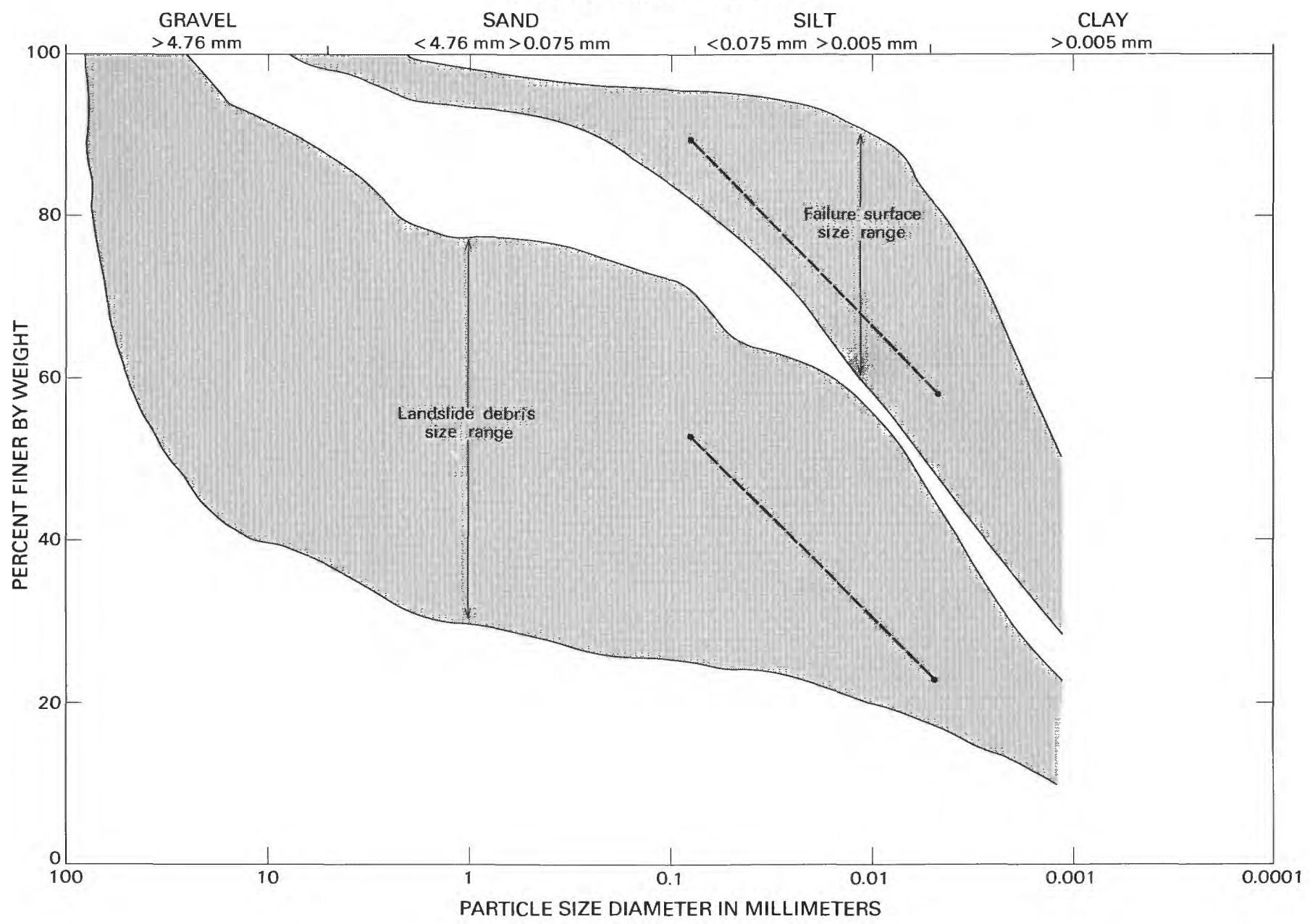

FIgURE 4.-Cumulative curves of range of gradation for 10 samples of landslide debris (samples 2-11, table 1) and 8 samples of slip-surface materials. Dashed lines connect points for average amounts of clay-size and clay-plus-silt-size fraction. Note that the slopes of the dashed lines are about parallel. Thus, the principal difference between the materials is the absence of a coarse fraction in the slip-surface samples.

The failure surface contained in the block samples tended to be very thin and not perfectly planar. In order to obtain a test sample that included the thin failure surface, we attempted to trim undisturbed samples from the block with the failure surface in proper position and orientation for testing in a direct-shear device. The ideal sample for testing would have contained a smooth, planar failure surface within the $10 \times 10 \times 2-\mathrm{cm}$ sample block such that shearing would have occurred perfectly along the failure surface. Attempts to produce such a sample were unsuccessful. The obtained effective residual friction angles were much too high; they generally exceeded $25^{\circ}$. Inspection of the samples after testing revealed the presence of a few small stones, which interfered with creation of a smooth failure surface.

We also had problems with loss of sample during the test; sample material was extruded out of the sample box. The strength appeared to increase with increasing displacement. As fine-grained material was squeezed out of the sample carriage, more coarse material was left to interact with the failure surface. The problem of loss of sample was reduced by overconsolidating the samples to about four times the maximum-planned normal load. The surface to be tested was precut after consolidation. Tests were conducted under drained conditions at three different normal loads of about equal to, twice, and four times the estimated field loading conditions. This procedure facilitated formation of a good surface for residual-strength determination that conceptually is equivalent to the strength of the in-situ failure surface.

The results of the strength tests are in table 2. Test 2a produced the best data we could obtain on the 
TABLE 2.-Strength parameters for the failure surface of the Manti landslide

[LL, liquid limit; PI, plasticity index]

\begin{tabular}{|c|c|c|c|c|c|c|}
\hline \multirow[t]{2}{*}{$\begin{array}{l}\text { Block } \\
\text { No. }\end{array}$} & \multirow{2}{*}{$\begin{array}{c}\text { Dry } \\
\text { density } \\
\left(\mathrm{g} / \mathrm{cm}^{3}\right)\end{array}$} & \multicolumn{2}{|c|}{$\begin{array}{l}\text { Atterberg } \\
\text { limits }\end{array}$} & \multirow[t]{2}{*}{ Test of type } & \multirow{2}{*}{$\begin{array}{l}\text { Effective } \\
\text { residual } \\
\text { friction } \\
\text { angle } \\
\left(\phi_{r}^{-}\right), \text {in degrees }\end{array}$} & \multirow[t]{2}{*}{ Remarks } \\
\hline & & LL & $\overline{\mathrm{PI}}$ & & & \\
\hline $2 a$ & 1.62 & 56 & 31 & Direct shear & 24 & $\begin{array}{l}\text { Test on natural failure } \\
\text { surface. }\end{array}$ \\
\hline $\mathrm{b}$ & 1.62 & 56 & 31 & Ring shear & 10 & $\begin{array}{l}\text { Remolded minus } \$ 230 \text { sieve } \\
\text { fraction. }\end{array}$ \\
\hline c & 1.62 & 56 & 31 & Direct shear & 13 & Do. \\
\hline $3 a$ & 1.60 & 64 & 40 & -- do- ----- & 12 & Do. \\
\hline b & 1.60 & 64 & 40 & Ring shear & 8 & Do. \\
\hline
\end{tabular}

natural failure surface and resulted in an effective residual angle of internal friction of $24^{\circ}$. The other four tests were run on remolded and scalped samples of the block samples. Materials were wet sieved through the \#230 screen. For tests $2 a$ and $3 a$, the material passing the screen was consolidated in the shear box and tested on a precut failure surface. The effective residual friction angles were $13^{\circ}$ and $12^{\circ}$. Two other tests, $2 \mathrm{~b}$ and $3 \mathrm{~b}$, were run using a ring-shear apparatus; and values of $10^{\circ}$ and $8^{\circ}$, respectively, were obtained.

The limited success of our attempts to test failuresurface materials prevented accurate characterization of the strength parameters. A reasonable value for the effective residual friction angle for a fully developed failure surface is probably about $12^{\circ}$. The strength of intact debris is much larger than the strength along the failure surface. The effective peak angle of internal friction of the landslide debris exclusive of failure-surface materials is probably in the range of $28^{\circ}$ to $32^{\circ}$, with an undetermined amount of cohesion.

The exposed failure surface on the upper ramp (fig. 3 ) is underlain and supported by a massive sandstone bed in the North Horn Formation. Sandstone outcrops occur to the west of the landslide. We also exposed sandstone by digging under the failure surface in a few places. The exposed failure surface is on the west side of the landslide; on the east side, it is buried by a thin veneer of loose landslide debris and a jumble of downed aspen trees. In general plan, the surface appeared planar and dipped slightly east of the direction of movement, giving the impression that the thalweg of the buried valley is on the east side of the landslide.

In detail, the failure surface was visibly striated with grooves a few millimeters deep. No coarse particles were exposed in the surface. In figure 4 , note the lines connecting average clay-size and clay-plus-silt-size fractions. The two lines are almost exactly parallel. Thus, the difference in gradation between failure-surface materials and landslide debris is the absence of coarse fragments along the failure surface. Apparently, the materials along the failure surface were mechanically depleted of coarser material with accumulating displacement (fig. 5).

We excavated through the surface in a few places and commonly found a second failure surface much like the one exposed. The distance between the failure surfaces varied from a few centimeters to a few tens of centimeters. In each case, the failure surface was thin and devoid of coarse material. We did not visit the locality to sample the surface until the summer of 1976 , and the material was undoubtedly drier than at the time of failure. Even at that time, however, the water content was above the plastic limit; the overlying landslide debris appeared dry.

\section{VOLUME OF THE LANDSLIDE}

Two drill holes placed in the vicinity of the waterline crossing and 10 short refraction seismic lines scattered on and near the landslide provided depth to the failure surface at a few points. We used data from three points on the landslide to estimate its volume. Values for depth to the failure surface were obtained from a boring near the waterline crossing, on the ramp below the upper bench where the failure surface was exposed, and on the floor of the Cottonwood Reservoir site on the lower bench (pl. 1).

The displacement of the landslide resulted in large scarps on the flanks; these were created by thinner debris from upslope on the landslide moving downslope and occupying the former position of thicker debris. Striations on the scarps generally indicated slopeparallel displacements. In a few places on the flanks of the landslide, displacement produced outward-facing scarps (fig. 6) where a thicker and (or) wider portion of 


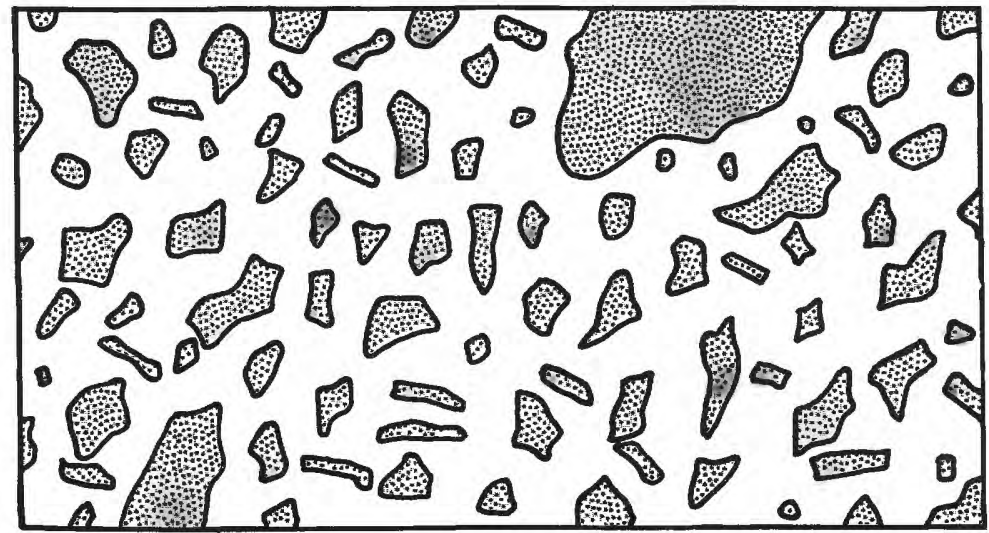

A
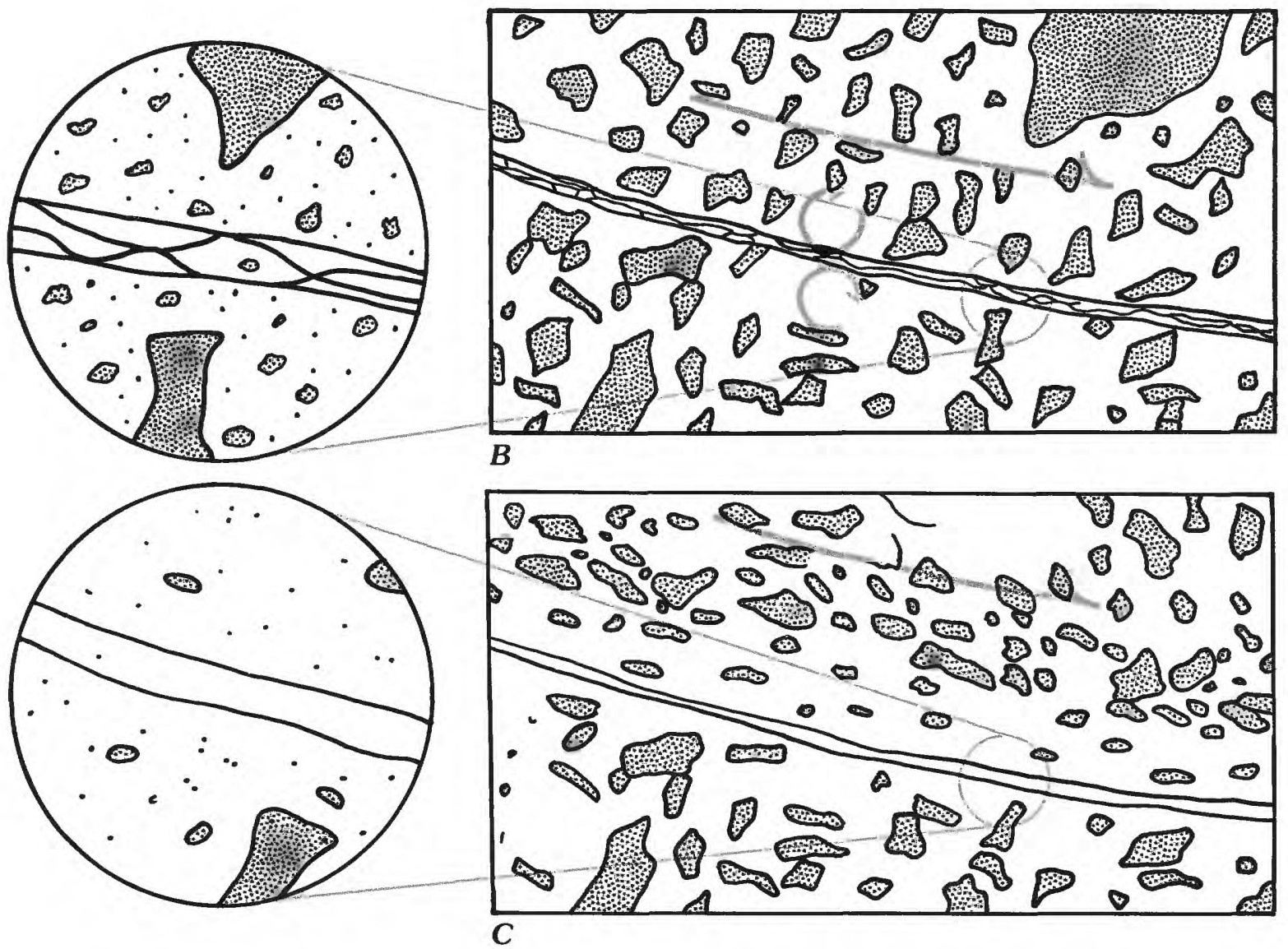

Figure 5.-Sketch of two stages in the process of mechanical depletion of the coarse fraction from a failure surface. $A$, Prior to failure, coarse clastics are scattered throughout the material. $B$, As a failure surface propagates through the material, the coarser clastics rotate out of the failure zone. $C$, With continuing displacement, a thin failure surface evolves that is depleted of sand and coarser size material. In places where the failure surface is exposed, multiple surfaces can be found by digging. In each case, the failure surface is no more than $1 \mathrm{~cm}$ thick and contains no coarse clastics. (Sketch modified from Wahlstrom and Nichols, 1969.)

The mass was translated to a place where the landslide had been thinner or narrower. Knowing the depth to the failure surface at three points, the amount of displacement, and the scarp heights, an estimate of depth could be obtained for any other point. The procedure is analogous to the method, outlined by Jakobson 


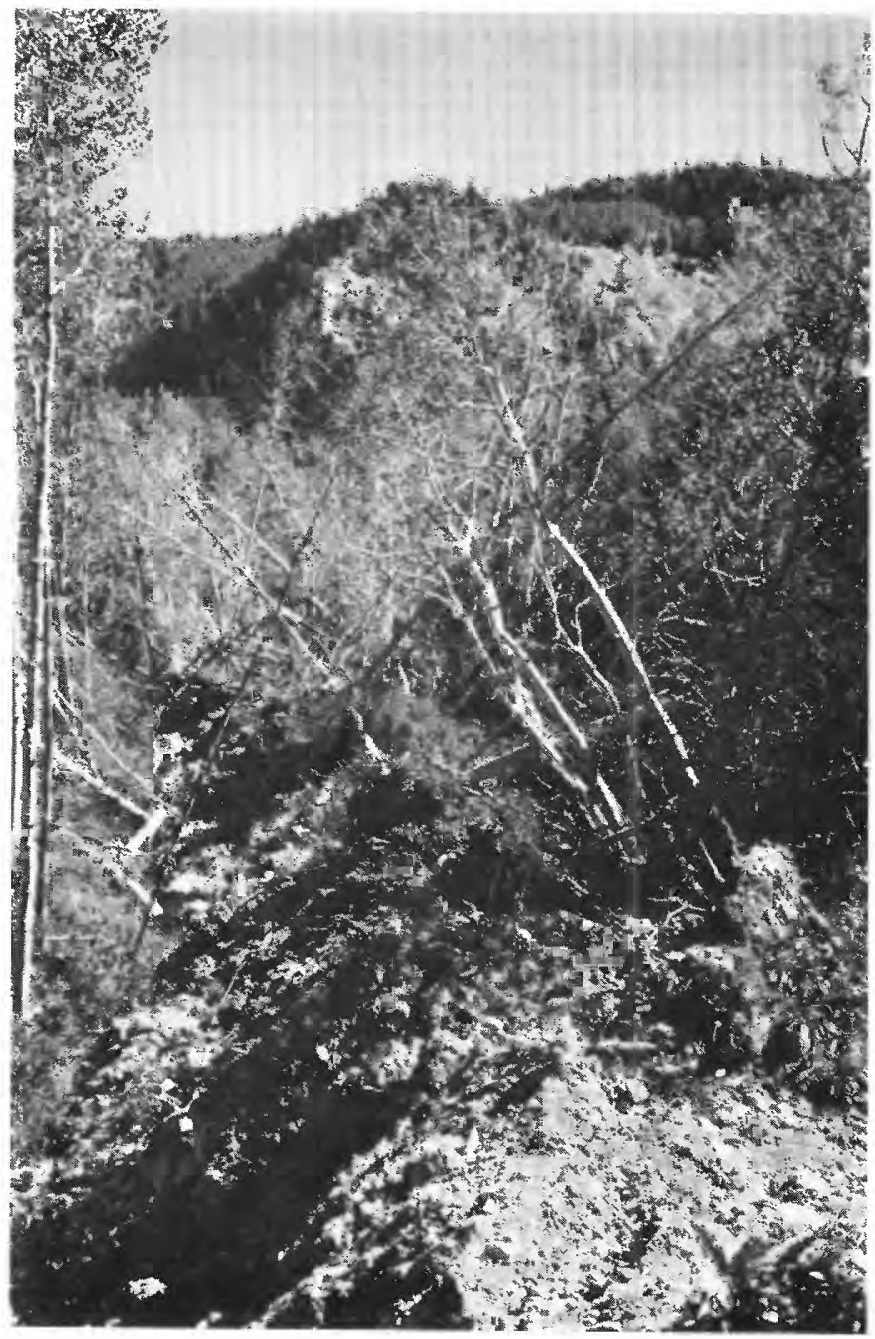

FIGURE 6.-Outward-facing scarp on the right flank of the upper part of the landslide. Displacement resulted in the failed debris being elevated about $3 \mathrm{~m}$ above the undisturbed surface outside the landslide.

(1952), of depth estimation using the form of grabens in the head of a landslide.

Using the scarp height and the displaced thickness from upslope, we estimated the volume on the basis of the thickness of the landslide near each flank. The failure surface was assumed to be a straight-line connection of those points. This assumption does not take into account variations in the failure surface introduced by irregularities in the underlying bedrock surface. In general, the landslide became consistently thicker downslope, ranging from $8 \mathrm{~m}$ in the upper part to about $28 \mathrm{~m}$ on the west side of the landslide near Cottonwood Reservoir. Downslope from Cottonwood Reservoir, an outfacing scarp on the west flank (see Chapter A, fig. 11 , this volume), ranging in height from 5 to $15 \mathrm{~m}$ above the adjacent, unfailed material in a reach of constant slope, is evidence that the thickness was decreasing as the landslide toe propagated to Manti Creek.

The area of failed material was computed for $13 \mathrm{sec}-$ tions drawn normal to the direction of movement and the volume was obtained by mechanical integration assuming no volume changes in the landslide debris. The estimated total volume of the reactivated Manti landslide was $19.4 \times 10^{6} \mathrm{~m}^{3}$. If allowance is made for assumed dilatancy of debris during failure, the prefailure volume was about $18.5 \times 10^{6} \mathrm{~m}^{3}$. About half of the volume, $8.7 \times 10^{6} \mathrm{~m}^{3}$ was contained in the lower part of the landslide between the upslope end of Cottonwood Reservoir and the toe of the landslide. Less than 10 percent of the total volume, about $1.5 \times 10^{6} \mathrm{~m}^{3}$, was reactivated in 1974, whereas the remainder began moving during the spring and summer of 1975 .

In areas where the angle of the failure surface remained relatively constant, upright trees were transported more than $50 \mathrm{~m}$ without extensive disturbance. However, changes in the slope of the failure surface produced extensive internal cracking. In simple situations such as where landslide debris spilled over the upper and lower benches, the cracks were predominantly extensional and normal to the direction of movement. At the base of ramps, where the failure surface was concave upward, the landslide debris was thoroughly disrupted and trees were scattered like matchsticks over the surface.

Apparently, some of the ponds on the surface of the landslide before failure were located in low areas of the underlying failure surface. When the landslide was displaced in 1974, the ponds remained at about the same places as before movement, but the silt-laden floors of the ponds were displaced downslope.

\section{SHAPE OF THE BURIED VALLEY}

The landslide debris has been previously described as consisting of debris-flow deposits that filled a preexisting topographic depression. Deposition in the depression apparently began nearly $20,000 \mathrm{yr}$ ago, and by the time of reactivation of the landslide in 1974 the shape of the former valley had been obscured. Following reactivation, the thalweg of the buried valley could be identified where it cut through the sandstone-supported upper and lower benches. It is located in the middle of the landslide from the crown to the upper bench of the landslide, and from that point to about the highest uphill-facing scarp (pl. 1), it is on the east side of the landslide. Under the area of uphill-facing scarps on the lower bench, it crosses to the west side of the landslide and proceeds along the west flank to Manti Creek. 


\section{DISPLACEMENT OF COTTONWOOD RESERVOIR}

The displacement of Cottonwood Reservoir is complex. Maps prepared of the shoreline of the reservoir and used to calculate displacement showed that the reservoir not only was displaced but also internally strained and perhaps rotated. The displacement of the west side of the reservoir was directed $10^{\circ}$ west of the displacement direction of the east side (fig. 7). The sense of motion on the internal cracks to the east of the reservoir cannot be determined from the aerial photographs, but the distortion in the reservoir shape suggests that internal strain provided small right-lateral shear components to their movement. If so, displacement directly over the sandstone-supported lower bench was inhibited by the low slope and shallow bedrock, and was forced in a westerly direction. The net result was that the landslide above the lower bench tended to lock on the west side and separate on the east side.

We attempted to analyze the changes in the shape of the reservoir shoreline as related to time. Outlines of the shoreline, as expressed on aerial photographs, were traced using a PG-2 plotter on a planimetric projection at a scale of 1:4,800. Points that could be identified on sequential aerial photographs were assigned $x, y$, and $\mathrm{z}$ coordinates. Using a finite strain technique, Rex L. Baum (U.S. Geological Survey, written commun., 1984) analyzed changes in the shape of triangles formed by three shoreline points. Internal cracking in the reservoir floor produced nonhomogeneous deformation and large differences in the directions and amounts of principal stretches. However, the strain directions were more consistent on the west side of Cottonwood Reservoir than on the east, and some crude interpretations are possible. The most consistent pattern in the strains was a tendency for the principal stretch to be oriented at right angles to the direction of displacement as the landslide enlarged during the summer of 1975 . After movement had propagated to Manti Creek, the principal stretches tended to be parallel to the direction of displacement. This pattern is what we would expect. The failure surface propagated under the reservoir in response to loading from upslope; this produced stretching normal to the direction of propagation. Subsequent rapid displacement on the fully developed failure surface resulted in stretching parallel to the displacement direction.

We have considered the Manti landslide to be a translational landslide; that is, the landslide behaved as a deformable body with sliding on one or more discrete failure surfaces as the principal form of movement. If that is the case, internal features such as cracks and wrinkles should be the result of differences in displacement rate and variations in boundary geometry. Viewed from a distance, the landslide has the appearance of an earthflow. And, indeed, some references to the feature have termed it a landflow or flow slide (for example, Olson, 1978).

The only piace where we could attempt to evaluate flow in the landslide was at the fenceline crossing (Chapter A, fig. 9, this volume). The fenceline was a zigzag fence constructed from logs of aspen trees. Each section of the fence consisted of logs 10-15 $\mathrm{m}$ long that were alternately stacked at their ends with logs of the next section. The picturesque zigzag pattern was necessary for support of the fence, but it made a poor reference for evaluation of flow in the landslide. On August 30,1976, when we tape measured the offset of the fenceline, the fence was relatively straight across most of the landslide. A zone within $30 \mathrm{~m}$ of each flank of the landslide appeared to contain distributed shear, but the type of construction of the fence precluded detailed measurements. Within the body of the landslide, the zigzag pattern had been destroyed. The logs were more or less end to end, indicating that the fence had been stretched. Part of the stretch was caused by the difference in displacement on opposite sides of the landslide, and part was due to widening of the landslide downslope from its pre-landslide position. The initial length of the fence on the landslide was about $100 \mathrm{~m}$; the lengthening caused by the difference in displacement and widening was about $20 \mathrm{~m}$. Any internal flow that might have occurred was obscured by landslidecaused features.

Keefer and Johnson (1983) studied earthflows in California and obtained careful measurements of the relative amounts of sliding and flow. They found only a very small amount of distributed shear (flow) in features that contained all the morphological requirements for earthflow; most movement was the result of sliding. Similarly, Crandell and Varnes (1961) measured only a small amount of flow superimposed on extensive sliding movement in the Slumgullion earthflow. This is probably also the case for the Manti landslide, but the amount of flow is unknown.

\section{MODE OF REACTIVATION}

The sequence of reactivation of the landslide suggests that movement, in part, occurred along a preexisting failure surface and, in part, created a new failure surface. The upper part of the landslide responded quickly to the surcharge and to the undrained loading imposed by the debris-flow deposit. Deformation propagated to the toes of previous movement that were identifiable on pre-1974 aerial photographs (Chapter A, fig. 8 , this volume) and created new internal toes farther 


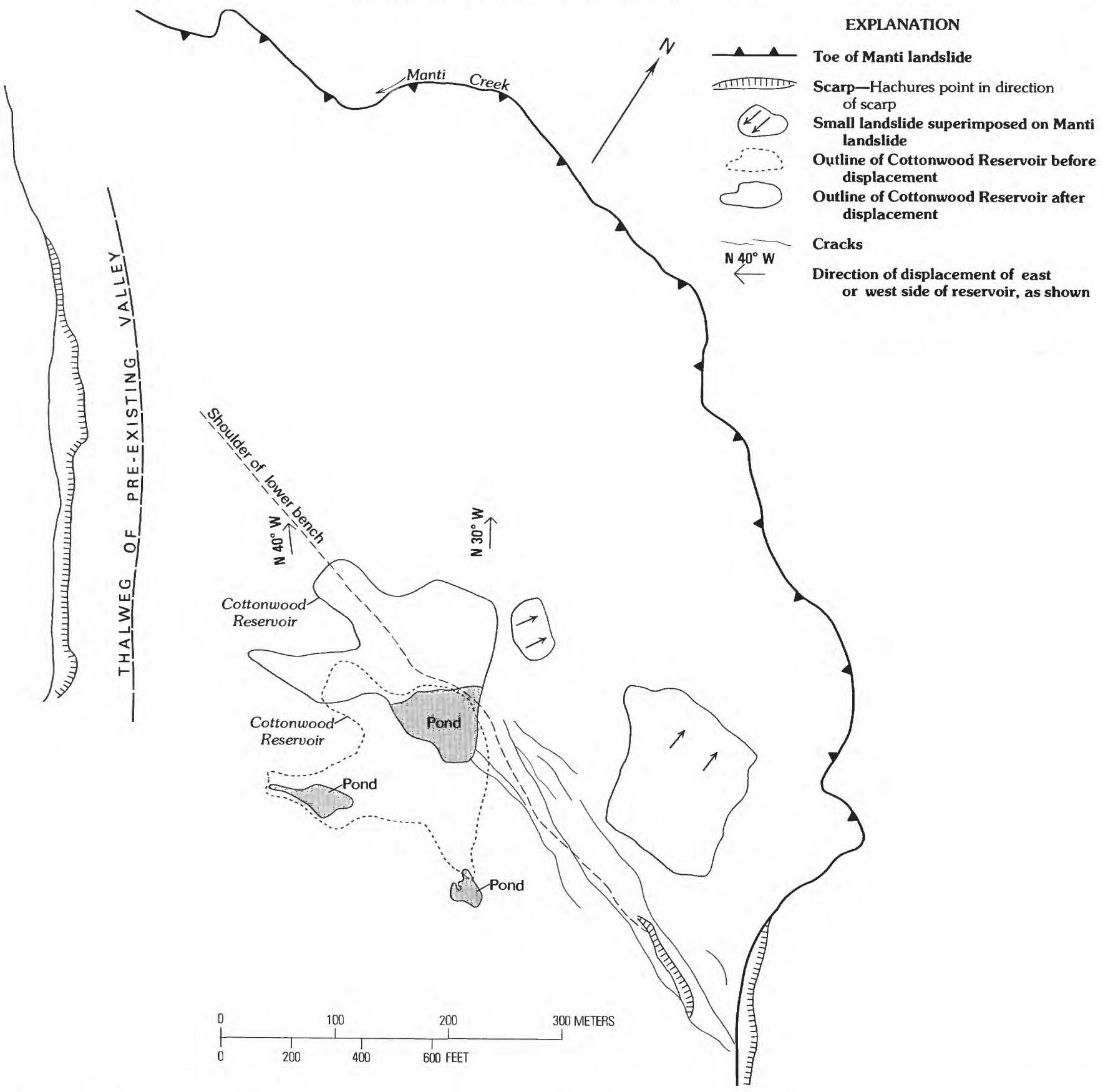

Figure 7.-Displacement of Cottonwood Reservoir over the shoulder of the lower bench. The solid outline of the reservoir is its pre-failure location, and the dotted outline is its position on June 21, 1979. The arrows show the difference in direction of displacement of the east and west sides of the reservoir.

downslope. However, before movement was detected at Manti Creek, $44 \mathrm{~m}$ and $73 \mathrm{~m}$ of displacement of the east and west flanks of the landslide occurred at the fenceline crossing. The creation of a series of internal toes, the lowest of which was near the upslope side of Cottonwood Reservoir, is indicative of restraint farther downslope. A new failure surface was created for the part of the landslide between Cottonwood Reservoir and the bank of Manti Creek.

Plate 1 includes a cross section of the landslide drawn from the map and topography of November 6, 1975 (Chapter A, fig. 10, this volume). The cross section shows the internal toes and inferred position of the new failure surface relative to the speculated position of the 
older and deeper surface of the inactive landslide. As the strength along the failure surface was reduced as a result of several meters of displacement, the rate of sliding in the lower part of the landslide greatly exceeded the rate farther upslope. This produced a difference in displacement that tended to pull the landslide apart and to produce large uphill-facing scarps in the former areas of internal toes. Displacement at Manti Creek was approximately horizontal, and movement of the toe deflected and elevated the channel of Manti Creek. Williams (Chapter C, this volume) discusses changes in the creek produced by the landslide.

Figure 8 is a simple schematic model for the reactivation of the landslide, considered to consist of two parts. In the upper part, the strength in 1974 was equal to the effective residual friction angle of $\phi_{\mathrm{r}}^{\prime} \approx 12^{\circ}$. The strength in the lower part was equal to the peak strength of the debris $\left(\phi_{\mathrm{p}}^{\prime} \approx 30^{\circ}\right)$. The preexisting failure surface for the old, inactive Manti landslide was apparently too deep to accommodate sliding. We think that the old failure surface for the lower part of the inactive landslide conformed to a much deeper channel of Manti Creek. More recent movement of the North slide and aggradation of the channel have changed the permissible geometry of the reactivated landslide. The rapid failure of the upper part of the landslide increased the loading conditions in the lower part of the landslide, which ultimately reduced the peak strength of the debris to a residual friction angle of about $12^{\circ}$ along a new and more convenient failure surface.

Whether the strength along the new failure surface is actually at a residual level cannot be proven. On the one hand, $100 \mathrm{~m}$ of displacement should be sufficient to produce a surface of minimum shearing resistance. On the other hand, once the stimulus for movement from the upper part of the landslide was relieved, the landslide virtually stopped.

By 1979, the landslide had separated into three relatively independent parts. The upper part consisted of all the material between the upper bench and the crown. During the fall of 1975 , it physically separated on the upper ramp from the landslide debris farther downslope. The second part consisted of the reach between the base of the upper ramp and the lower bench. The lower bench has served as a buttress tending to deflect the displacement toward the buried thalweg on the west flank of the landslide. The third part was the toe region of the landslide, where stability was adjusted to the channel of Manti Creek and generally independent of the remainder of the landslide upslope. Several small landslides and debris flows have occurred in the landslide debris on the lower ramp. During the spring of 1983, when melting of a near-record snowpack was triggering numerous reactivations of large, old landslides on the flanks of the Wasatch Plateau, the Manti landslide was conspicuously inactive.

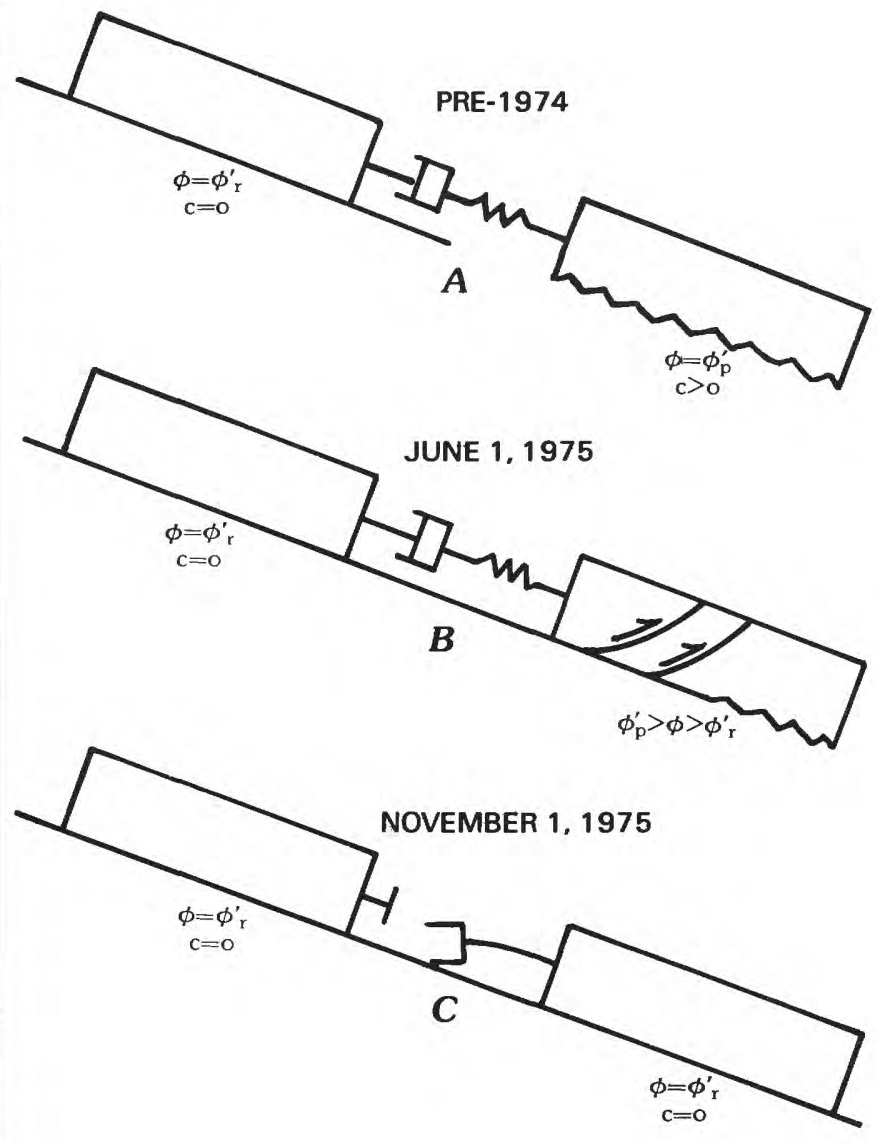

FIGURE 8.-Schematic model for reactivation of the Manti landslide. $A$, Before reactivation, the upper portion of the landslide before reactivation was creeping at a rate of less than $4 \mathrm{~cm} / \mathrm{yr}$. A small amount of strain energy was being stored in the toe of the movement zone (for location, see Chapter A, fig. 8, this volume). The stored strain energy increased dramatically after reactivation in early June 1974. The strength of the upper part of the landslide was at a residual value, while the strength of the lower part was at or near a peak value. $B$, Displacement of as much as $70 \mathrm{~m}$ had occurred in the upper portion of the landslide before movement was recognized in the lower portion. Internal toes were forming in response to extreme loading from upslope. The strength parameters of the lower portion were progressively reduced from a peak value of about $\phi_{\mathrm{p}}^{\prime} \approx 30^{\circ}$ with an unknown amount of cohesion to a residual friction of $\phi_{\mathrm{r}}^{\prime} \approx 12^{\circ}$. C, Lower portion of the landslide has a well-developed failure surface, and strength has been reduced to residual values throughout the failure surface. Lower portion of the landslide near Cottonwood Reservoir was moving at about $3.1 \mathrm{~m} / \mathrm{d}$ at the same time the upper part was moving at about $0.3 \mathrm{~m} / \mathrm{d}$. The landslide separated on the upper bench, and the two portions of the landslide were moving independently and no longer in physical contact.

\section{CONCLUSIONS}

The Manti landslide occurred in debris that accumulated from multiple episodes of debris flows. The debris flows filled a preexisting valley tributary to Manti Creek during the last $20,000 \mathrm{yr}$ and subsequently failed by 


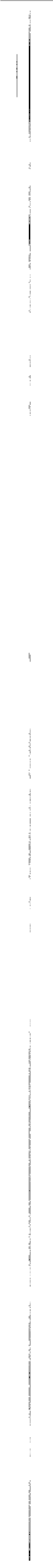


landsliding. Large displacements have resulted in a failure surface with markedly different properties from those of adjacent landslide debris. Differences in plasticity characteristics, gradation, clay mineralogy, and strength are pronounced between the landslide debris and the failure-surface materials.

The Manti landslide was reactivated entirely within the boundaries of a larger, inactive landslide. The style of the reactivation suggested that movement occurred, in part, on the preexisting failure surface of the old, inactive landslide and created, in part, a new failure surface.

\section{REFERENCES CITED}

Crandell, D. R., and Varnes, D. J., 1961, Movement of the Slumgullion earthflow near Lake City, Colorado: U.S. Geological Survey Professional Paper 424-B, p. B136-B139.

International Engineering Company, Inc., 1976, Interim geotechnical report, Manti Canyon North slide stability studies: Unpublished report on file at the office of the U.S. Forest Service, Ogden, Utah, $98 \mathrm{p}$.

Jakobson, B., 1952, The landslide at Surte on the Gota River: Royal Swedish Geological Institute Proceedings, no. 5, $121 \mathrm{p}$.

Keefer, D. K., and Johnson, A. M., 1983, Earthflows: Morphology, mobilization, and movement: U.S. Geological Survey Professional Paper 1264, 56 p.

Olson, E. P., 1978, Cottonwood complex, part 2 of Landslide investigation, Manti Canyon: U.S. Department of Agriculture, Forest Service, Report G-R4-78-2, April 13, 1978, 53 p.

Robinson, S. L., 1977, Geologic analysis of the Manti landslide, Manti, Utah: Fort Collins, Colorado State University M.S. thesis, 103 p. Rodine, J. D., 1974, Analysis of the mobilization of debris flows: Stanford, California, Stanford University Ph.D. thesis, $226 \mathrm{p}$.

Wahlstrom, E. E., and Nichols, T. C., Jr., 1969, The morphology and chronology of a landslide near Dillon Dam, Colorado: Engineering Geology, v. 3, p. 149-174. 


\section{Stream-Channel Changes and Pond Formation at the 1974-76 Manti Landslide, Utah}

By GARNETT P. WILLIAMS

THE MANTI, UTAH, LANDSLIDE

U.S. GEOLOGICA L S UR VEY PROFESSIONAL PAPER 1311 - C

Hydrologic effects of the Manti landslide, particularly pond formation, on the landslide surface and changes in the channel of Manti Creek at the toe of the landslide 



\section{CONTENTS}

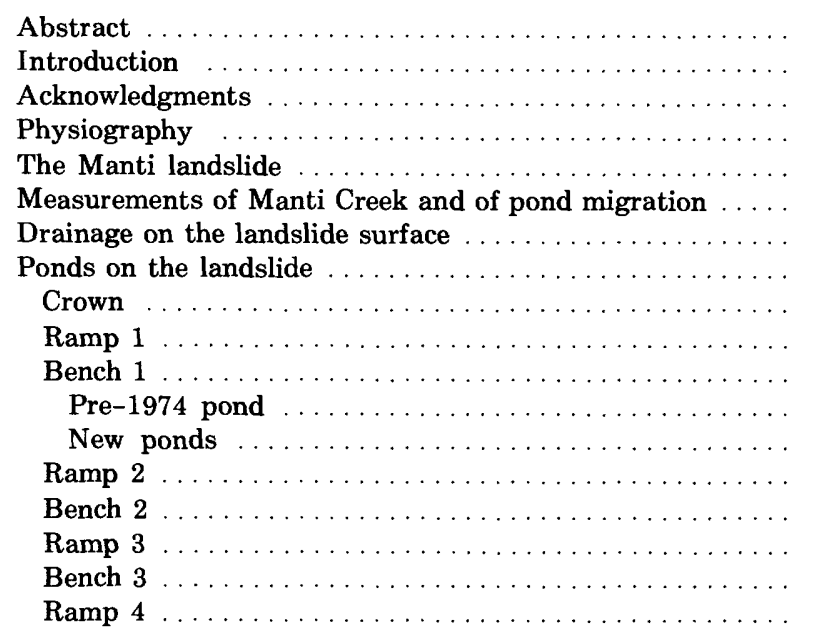

Page

47

47

47

48

48

49

50

51

52

52

52

52

52

52

53

54

54
Ponds on the landslide-Continued

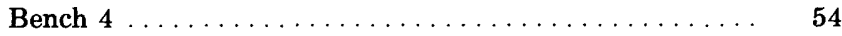

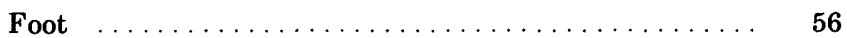

Chronology of pond appearance $\ldots \ldots \ldots \ldots \ldots \ldots \ldots \quad 56$

Pond sediments as tools for dating landslide activity ... $\quad 57$

Manti Creek .............................. 58

Sediment introduction from the landslide ........ 58

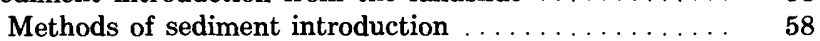

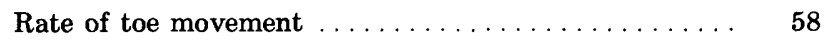

Type and sizes of sediment .............. 58

General nature and pattern of Manti Creek . . . . . . 60

Channel cross-section characteristics ............ 61

Lateral displacement $\ldots \ldots \ldots \ldots \ldots \ldots \ldots \ldots \ldots \ldots, 61$

Average width of streambed $\ldots \ldots \ldots \ldots \ldots \ldots \ldots \ldots, 62$

Channel aggradation and longitudinal profiles ....... 62

Bed armoring and sediment transport $\ldots \ldots \ldots \ldots \ldots .65$

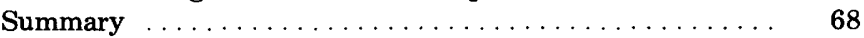

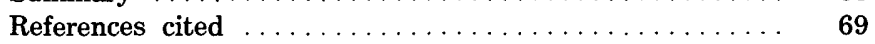

\section{ILLUSTRATIONS}

FIGURE 1. Map showing outline and principal hydrologic features of the Manti landslide

2-8. Photographs:

2. Cliff at head of landslide .

3. Upstream view of the western drainageway on the landslide, about at lower boundary of ramp $1 \ldots \ldots \ldots$

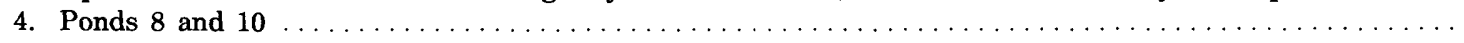

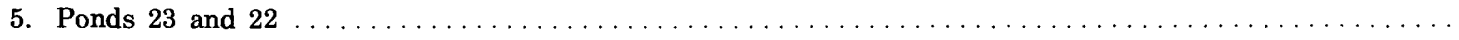

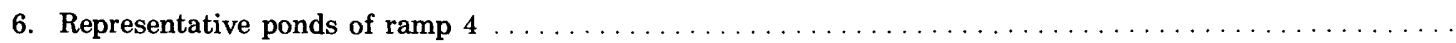

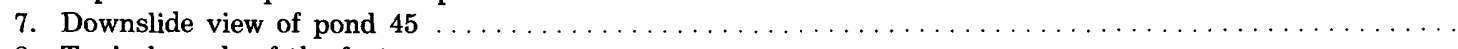

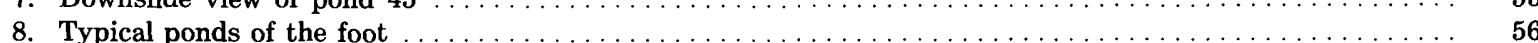

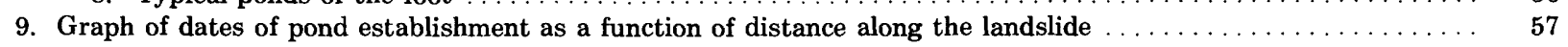

10. Time-sequential photographs showing sediment introduction at a site in the downstream part of the Manti Creek slide

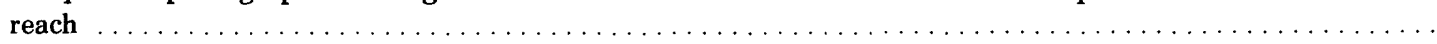

11. Graph of representative size-frequency distribution of toe sediment, Manti landslide $\ldots \ldots \ldots \ldots$

13. Photograph showing downstream view of braided section that separates cascade 1 from cascade $2 \ldots \ldots \ldots \ldots \ldots$

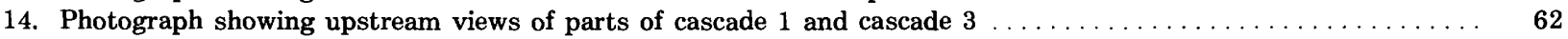

15. Graph showing cross-sectional changes on Manti Creek at selected times $\ldots \ldots \ldots \ldots \ldots$

16. Trace overlay showing lateral displacement of Manti Creek slide reach from September 19 to November 6, 1975

17-21. Graphs:

17. Longitudinal profiles of Manti Creek in the vicinity of the landslide .

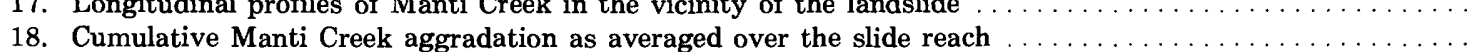

19. Standardized plot of cumulative Manti Creek aggradation versus time $\ldots \ldots \ldots \ldots \ldots \ldots \ldots \ldots \ldots$

20. Geometric mean diameter of smallest bed particles as a function of local channel slope $\ldots \ldots \ldots \ldots \ldots \ldots$

21. Average smallest bed-material diameter as a function of approximate highest unit stream power that acted on the post-slide streambed

.

1

3




\section{TABLES}

TABLE 1. Manti Creek channel dimensions as measured from aerial photographs

2. Channel properties along the slide reach 


\title{
STREAM-GHANNEL GHANGES AND POND FORMATION AT THE 1974-76 MANTI LANDSLIDE, UTAH
}

\author{
By GARNETT P. WILliams
}

\begin{abstract}
This paper deals with the hydrologic features (streams and ponds) associated with the 1974-76 landslide in Manti Canyon near Manti, Utah. The landslide is about $3.5 \mathrm{~km}$ long and $100-800 \mathrm{~m}$ wide. Mostly during the summer and fall of 1974 and 1975, it moved about $200 \mathrm{~m}$ down its track at relatively slow rates (typically about $1 \mathrm{~m} / \mathrm{d}$ ). The small (1-m-wide) stream flowing in the slide direction on the landshide surface maintained its approximate general position and course throughout the period of landshiding. The shding created about 63 new ponds on the landslide surface, the majority on the lower half. These ponds range from a few meters to nearly $150 \mathrm{~m}$ in length, and most are less than 1-2 $\mathrm{m}$ deep. Some are fed by the small stream that flows on the landslide surface, but most have no apparent inflow or outflow. An estimated $50,000 \mathrm{~m}^{3}$ of sediment from the landslide were introduced into a 1,000-m-long reach of Manti Creek at the toe of the landslide, mainly during about $11 / 2$ months in the fall of 1975 . The 8-m-wide channel at one cross section was reduced to about 60 percent of its pre-1974 cross-sectional area; other cross sections were reduced by lesser and probably greater percentages. The creek was displaced laterally by distances ranging from 0 to $33 \mathrm{~m}$, averaging $15 \mathrm{~m}$. Channel aggradation ranged from a meter or two to $35 \mathrm{~m}$, averaging nearly $15 \mathrm{~m}$. The maximum aggradation of $35 \mathrm{~m}$ at one location along the reach is among the highest reported amounts of channel fill due to landslides. The 1982 channel was armored; the smallest bedparticle diameters vary with the slope of the streambed and with the unit stream power estimated to have acted on the post-landslide streambed.
\end{abstract}

\section{INTRODUCTION}

Landslides, both active and dormant, are a common feature of the valleys of the Western United States. A landslide in this paper is defined as a slope movement wherein shear failure occurs along a specific surface or combination of surfaces (Schuster, 1978, p. 2). The effects of such mass movements of earth on local hydrology and on fluvial processes have received very little attention in the literature. Yet these movements can have a profound and largely unrecognized influence. For example, in the Teton National Forest in northwest Wyoming, landslides are the principal process by which sediment is supplied to streams (Bailey, 1971, p. 1).

An old landslide in the mountain valley of Manti Creek, near the town of Manti, Utah, in the central part of the state, became active again from 1974 to 1976. The slide is about $31 / 2 \mathrm{~km}$ long and gradually moved more than $200 \mathrm{~m}$ down its track, mostly during the summer and fall of 1974 and 1975. Periodic aerial photography was taken from 1974 to 1979 . These photographs, together with field observations made in 1982, form the basis of the present paper. The paper deals with the landslide's effects on local surface-water hydrology, specifically in regard to drainage and ponding on the slide surface and to changes in Manti Creek at the toe of the slide. Sediment effects along Manti Creek downstream from the slide were minor and will not be discussed.

\section{ACKNOWLEDGMENTS}

Aerial photographs and numerous valuable reports were made available to me by Earl Olson of the U.S. Forest Service, to whom I am also indebted for useful comments on the manuscript as well as for his general cooperation and encouragement. Richard Hadley and Thomas Winter also made helpful comments on the manuscript. Field assistance was rendered by Kerstin Williams and Robert O'Brien. For help in various other ways I thank Dick Allred, Ben Black, Diana Fair, and Ned Madsen.

\section{PHYSIOGRAPHY}

Manti Canyon is incised into the western rim of the Wasatch Plateau. The canyon is oriented east-west and 
is about $15 \mathrm{~km}$ long. It ranges in elevation from about $1,770 \mathrm{~m}$ above sea level at the mouth to about $3,200 \mathrm{~m}$ above sea level on top of the plateau. Although the climate of the general region is semiarid, precipitation locally varies with altitude and ranges from about $250 \mathrm{~mm} / \mathrm{yr}$ at the canyon mouth to about $1,000 \mathrm{~mm} / \mathrm{yr}$ at the canyon head.

The rock units exposed in Manti Canyon and in cliffs nearly $200 \mathrm{~m}$ high at the head of the landslide are freshwater sedimentary strata that lie nearly flat. The lower of the two formations, the North Horn Formation, consists of shales, sandstones, conglomerates, and limestones of Late Cretaceous and early Tertiary age. The overlying unit is the Flagstaff Member of the Green River Formation, which is Paleocene and Eocene in age; though mostly limestone, it has some shale and sandstone. Some faulting has occurred throughout the valley.

"The Manti Creek drainage basin is an excellent example of . . . 'landslide' topography" (Woolley, 1946, p. 11). One estimate indicates that more than 100 landslides, most of which now are inactive, have occurred in the canyon (Olson, 1977, p. 16).

\section{THE MANTI LANDSLIDE}

The Manti landslide is on the south side of the canyon, about $51 / 2 \mathrm{~km}$ up the canyon from the mouth. The $3-1 / 2$-km-long slide is relatively narrow, ranging in width from about 100 to $800 \mathrm{~m}$. The range in elevation is from about $2,100 \mathrm{~m}$ above sea level at the lower end of the landslide to about $2,620 \mathrm{~m}$ above sea level at the head. The overall average gradient therefore is about $0.15 \mathrm{~m} / \mathrm{m}$. Vegetation on the landslide includes conifers, aspens, scrub oak, various grasses, and many other varieties of plants.

The Manti landslide is an ancient landslide that has crept downhill intermittently at varying rates for centuries. The cause of the increased 1974-76 movement probably was a combination of three factors: (1) several early-1974 debris flows deposited on the head or crown of the landslide, followed by (2) increased water saturation of these deposits due to unusually rapid snowpack melting, and (3) a heavy April 1974 rainstorm (Robinson, 1977). Failure began on or about June 6, 1974, and affected approximately the upper $2,400 \mathrm{~m}$ of the landslide (Fleming and others, 1977). The rate of movement increased to about $1.1 \mathrm{~m} / \mathrm{d}$ by the end of June 1974 and then decreased to a very slow rate by early fall (Olson, 1977 , p. 20). Movement resumed about May 1975, after the winter lull, and by the end of August 1975 it had extended progressively to the toe of the slide at Manti Creek. The rates and amounts of movement during 1975 varied both areally and temporally. Maximum rates of movement probably were on the order of $1.2 \mathrm{~m} / \mathrm{d}$ (Olson, 1978). From 1976 to 1982 (the latest observation year for this report), the landslide at many locations continued to migrate, though at relatively reduced rates.

\section{MEASUREMENTS OF MANTI CREEK AND OF POND MIGRATION}

Measurements for this study were made both in the field (1982) and from aerial photographs. The dates of the aerial-photograph flights, with the associated scale in parentheses, are as follows: August 9, $1950(1: 20,000)$, September 11, 1964 (1:20,000), July 10, $1974(1: 12,000)$, June 12, 1975 (1:6,000), August 24, 1975 (1:6,000), September 1, $1975(1: 6,000)$, September 19, 1975 $(1: 6,000)$, November 6, $1975(1: 6,000)$, May 10, 1976 $(1: 6,000)$, and June 21, $1979(1: 4,800)$.

Most of the aerial-photograph measurements were made using a computer-assisted photogrammetric mapping system based on a Kern PG-2 plotter ${ }^{1}$. Elevations were referenced to mean sea level. Repeat trials of elevation measurements on a recognizable point of known elevation, using photographs of 1:6,000 scale, indicated a reproducibility of $\pm 0.3 \mathrm{~m}$. There is a possible error of about $1 \mathrm{~m}$ in the elevation above sea level as measured for any site on such photographs.

In regard to Manti Creek, the features measured on each set of aerial photographs were (1) a longitudinal profile of the channel bed (thalweg); (2) a plan-view trace of the thalweg; (3) two cross sections of identifiable fixed location, within the reach affected by the landslide (hereafter called the slide reach); and (4) the average channel-bed width within the slide reach. A July 1982 onsite survey included the same measurements except for the plan-view trace of the channel.

The longitudinal profiles of Manti Creek all began at a common starting point; namely, the channel bed under the downstream edge of a U.S. Forest Service road bridge that spans the creek about $270 \mathrm{~m}$ (channel distance) upstream from the beginning of the 1974 slide reach. The elevation of the bridge $(2,189 \mathrm{~m}$ above sea level) was accurately known. The profile was extended as far downstream as the aerial photographs enabled; in some cases, this was only a few tens of meters downstream from the end of the slide reach. The length of reach studied on the different sets of photographs ranged from about $960 \mathrm{~m}$ to $1,550 \mathrm{~m}$ and averaged approximately $1,350 \mathrm{~m}$. In aerial-photograph analysis, about 90 elevation readings were taken over the distance.

\footnotetext{
${ }^{1}$ Any use of trade names is for descriptive purposes only and does not constitute endorsement by the U.S. Geological Survey.
} 
By overlaying any two plotted longitudinal profiles, the change in bed elevation between the dates of the photographs, at any point along the reach, was easily measured. In addition, planimetering the area between any two overlain profiles along the reach gave the total scour or fill for the reach. Such area measurements carry a possible error of about 5 percent in the profile lineup and planimetering process. The elevation reproducibility of $0.3 \mathrm{~m}$, mentioned above, also could affect the planimetered area but statistically would be expected to affect both profiles equally. Therefore, the measured area between profiles should not be significantly affected by any error in elevation measurement.

The locations of the two channel cross sections were chosen mainly because these sites were identifiable on aerial photographs. A second reason was that the two sites represent reaches of relatively lesser (section one) and greater (section two) channel aggradation. The crosssection measurements permitted a determination of (1) the width at the topographic top of the channel, (2) the cross-sectional area referenced to the topographic top of the channel, (3) the maximum depth of the channel, (4) the channel shape, (5) the average channel bed width, and (6) the general lateral position of the channel relative to adjacent undisturbed terrain. A "banktop" in the usual fluvial sense could not be defined but was certainly much lower than the topographic top. The area and top width could not be measured at cross section two because the hummocky terrain of the landslide in that subreach (left bank of Manti Creek) had no recognizable "channel top" and the datum point on the opposite undisturbed side of the channel was above the unstable left side of the channel.

On each of the 10 sets of aerial photographs, three independent measurements were made of the top width at cross section one, and the average was taken as the representative top width for that date. The three measurements generally were within about 1 percent of the average width. The same procedure was used for cross-sectional area, and these individual measurements were within about 3 percent of the average area. Channel depth, as measured in this study, is a maximum depth; namely, the elevation difference between the channel top and the streambed. Channel shape can be crudely characterized by the width/depth ratio. This was calculated, using the top width and maximum depth, for cross section one. Average channel bed width within the slide reach was determined by averaging 10 measurements of bed width spaced approximately equidistantly along the reach.

Measurements of pond migration on the landslide were made directly on time-sequential aerial photographs. Generally, the measurements were made either from (1) an object of fixed position located on stable terrain outside the landslide, in line with the direction of slide movement, or (2) a baseline of fixed position drawn between two such fixed objects and about perpendicular to the slide direction.

\section{DRAINAGE ON THE LANDSLIDE SURFACE}

Both before and after the 1974-76 landslide, surface water was supplied to the crown (head) of the landslide via two grooves or gullies in the cliffside, about $20 \mathrm{~m}$ apart (figs. 1 and 2). (These same gullies carried the early-1974 debris flows that probably helped trigger the slide.) The general position of these two streamlets has remained virtually unchanged by the landslide activity. Water from the eastern gully flows along the east edge of the landslide for only a few hundred meters before leaving the slide (fig. 1). As of September 1982, this streamlet was about $0.3 \mathrm{~m}$ wide and $0.02-0.06 \mathrm{~m}$ deep. After leaving the landslide, it flows into Manti Creek.

Water from the western gully flows near the west edge of the landslide in the crown. Thereafter, the channel migrates laterally across the slide. Generally, the flow is in one channel, although at a few locations it splits into two or more channels (fig. 1). It enters Manti Creek at the northwest corner of the landslide at the foot (the lowermost region of the landslide). Typical September 1982 stream widths were less than about $1 \mathrm{~m}$, and flow depths were less than about $0.1 \mathrm{~m}$ (fig. 3). Comparison of the 1982 route with that shown on the 1965 USGS 7 1/2-minute topographic maps (Ephraim and Black Mountain quadrangles) and on 1964 aerial photographs indicates that the routes before and after the 1974-76 period did not vary appreciably. Thus, the little stream maintained its approximate general position and course throughout the considerable land migration and local disruption of the landslide surface.

There was one other drainageway prior to 1974 , a manmade ditch that routed water from a small creek to the east of the slide onto the slide in the vicinity of ramp 4 (fig. 1). (In this report the landslide surface is divided into various regions (fig. 1), primarily on the basis of the roller-coaster topography. Relatively steep zones, called ramps in this report, alternate with flatter sections, called benches.) The water from the ditch flowed along a natural channel on the slide surface and into Cottonwood Reservoir (pond 45 in fig. 1). (Cottonwood Reservoir had been maintained for the irrigation of farmland in the valley below the mouth of Manti Canyon.) From the reservoir, a man-controlled outlet routed water northward into Manti Creek. These drainageways above and below the reservoir were destroyed completely by the landslide and have not been reestablished. 


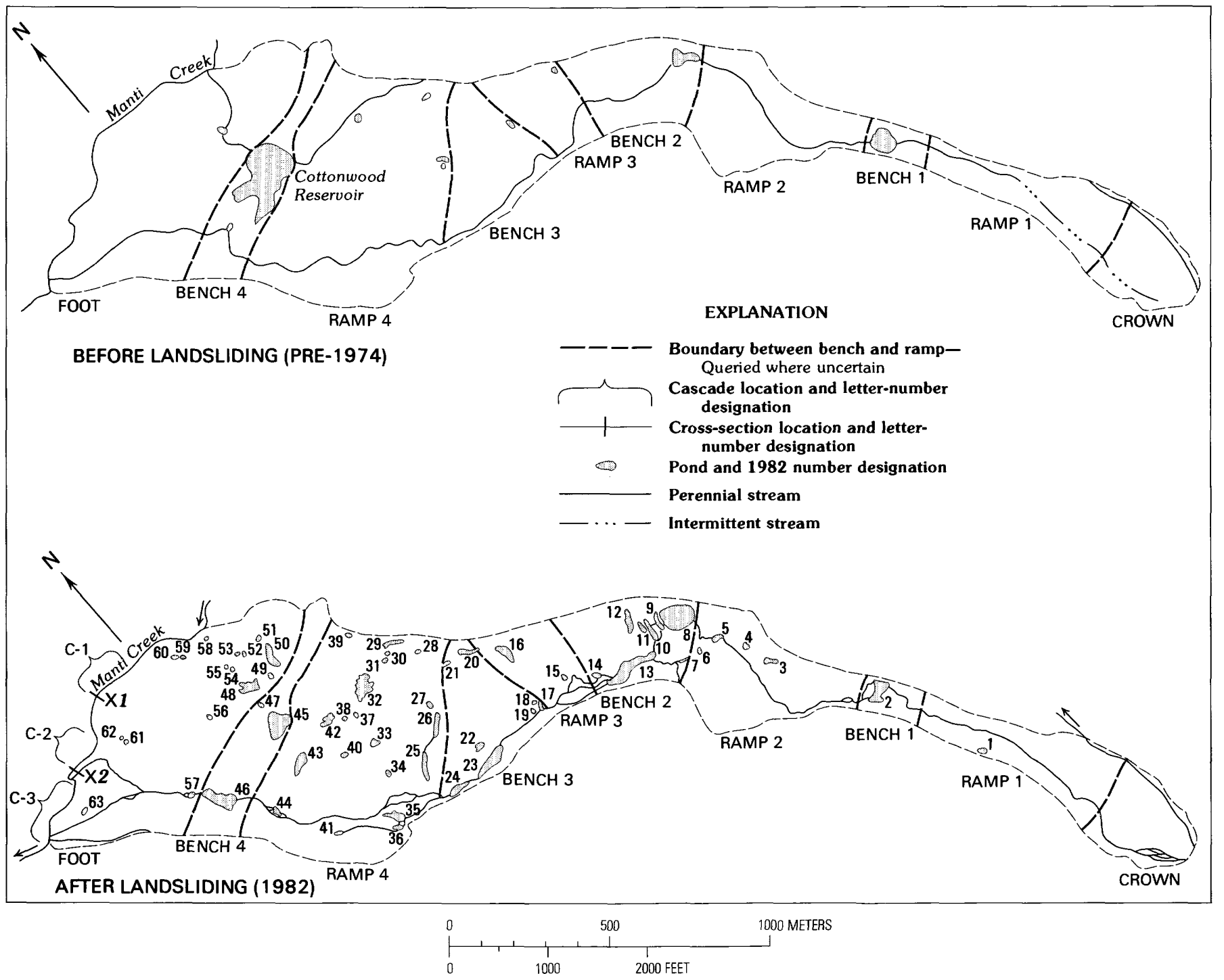

FIGURE 1.-Outline and principal hydrologic features of the Manti landslide. Pre-1974 map is based on aerial photography and on U. S. Geological Survey topographic maps (1982 physiographic regions shown for comparison); 1982 map is based on field observations and on 1979 aerial photography.

Ground water emanating from seeps on the landslide or on the nearly undisturbed terrain just off the edge of the slide forms trickles of surface flow at various locations. Such flow, in some instances, joins the main drainageway, but in other instances it feeds ponds or simply disappears into the ground.

A longitudinal trough typically borders the landslide on each edge. Although topographically low relative to the center of the slide, these troughs are not part of the main drainageway, except at the crown. They probably carry some flow during storms, however.

The channel pattern of the 1982 surface drainageway ranges from nearly straight to pronounced meandering; a slightly sinuous pattern is most common.
Bed-material sizes range from clay to cobbles, all quite angular (fig. 3). Channel width rarely exceeds $2 \mathrm{~m}$, and bankfull depths in most cases are less than about $1 \mathrm{~m}$.

\section{PONDS ON THE LANDSLIDE}

One of the more striking hydrologic aspects of the landslide is the many new ponds, all apparently permanent, which were created on the landslide surface. Most of the pre-slide ponds tended to be dry much of the time, but even counting such dry ponds, the landslide had only about 10 or 11 ponds before 1974 . Postslide ponds contain water the entire year, and a 1982 


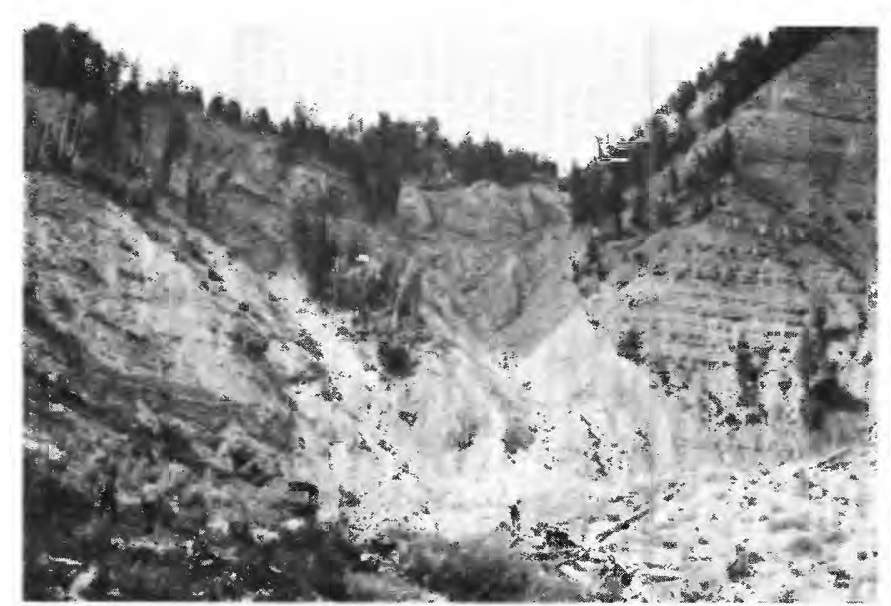

Figure 2.-Cliff at head of landslide, showing gullies that periodically carry debris flows and that perennially carry surface water. People in foreground indicate scale. Photograph taken July 1982.

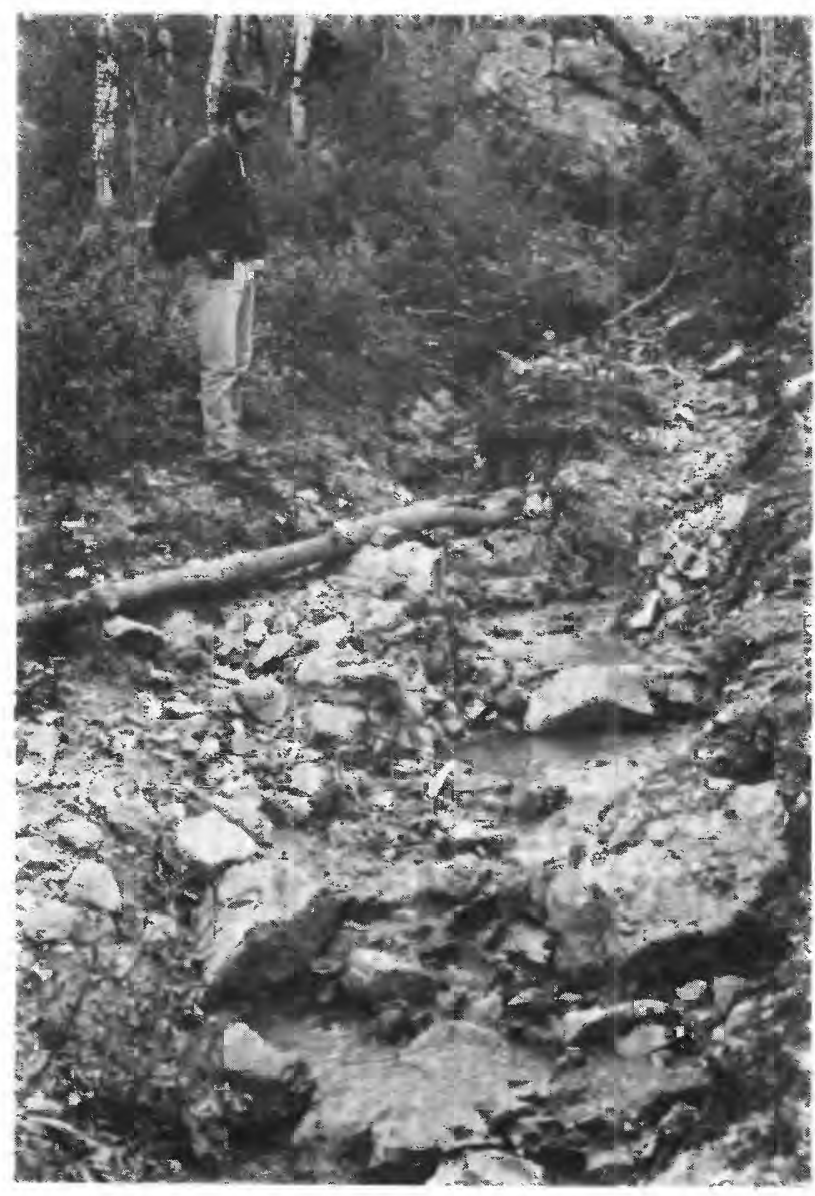

Figure 3.-Upstream view of the western drainageway on the landslide, about at lower boundary of ramp 1, September 1982.

onsite inspection revealed at least 63 such ponds, most in the lower half of the landslide. The change in number of ponds on the landslide is indeed curious, and landslide-triggered pond formation would be an interesting research topic. Both the 1982 and pre-1974 ponds are shown in figure 1; the 1982 ponds have been numbered approximately according to distance from the head of the slide.

Most of the pre-1974 ponds were destroyed by the landslide. Aerial photographs indicate that the first step in pond destruction was a transverse upwarping of the ground surface (including pond beds), usually with simultaneous transverse fissuring. Next, downslope migration set in, along with an increase in the upwarping and fissuring. These steps ordinarily were enough to destroy the smaller ponds, whereas the larger ones, such as Cottonwood Reservoir (pond 45), had a better chance of survival.

The 1982 ponds range in length from a few meters to about $150 \mathrm{~m}$. Pond length is the straight-line distance between the most distant points on the shore, as measured through the water or through the area that would be covered by water when the pond is full. Pond width at any point is the shore-to-shore distance, under full-pond conditions, as measured at right angles to the line defining pond length.

The post-slide ponds are of two general types: (1) open ponds interspersed in the slide-surface stream system with an upstream surface-water inflow and a downstream outflow, and (2) closed ponds with no apparent surface-water stream inflow or outflow. The terms open and closed are used loosely here; some water, for example, could enter or leave a closed pond via ephemeral overland surface runoff. Of the 63 post-slide ponds, 15 are of the open variety and 48 are closed. Open ponds tend to be muddy and opaque. Most of them have beaver dams at their outlets; how essential the beaver dams are in creating these ponds is unknown. Closed ponds have stagnant water; in most cases, this water is relatively clear and has some algal growth.

Most ponds occupy flat depressions, but others (transverse or trough ponds) formed behind transverse ridges of earth created by the landslide. Both the open and closed types occur in each of these topographic situations.

Post-slide ponds tend to have distinctly different shapes from pre-1974 ponds. Smooth shorelines and rather regular shapes characterized the pre-1974 ponds. In contrast, many post-slide ponds have much more irregular perimeters. Others, such as those that occupy troughs behind transverse ridges, are much longer than they are wide.

\section{CROWN}

The crown had no ponds prior to 1974 . The early-1974 debris flows created two large ponds at the base of the 
cliffside, each, judging from aerial photographs, an estimated $30-50 \mathrm{~m}$ long. The ponds were fed by runoff down the two gullies at the head of the slide (fig. 2). These ponds contained water on an irregular basis and disappeared "permanently" by the summer of 1976 . Their demise was brought about not only by normal stream erosion, but also by man (bulldozing).

\section{RAMP 1}

Ramp 1 also had no ponds before 1974. As of 1982, it had one small pond (length about $10 \mathrm{~m}$, width about $1 \mathrm{~m}$, water depth about $0.3 \mathrm{~m}$ ) in the topographic trough along the left edge of the slide. The pond has no visible surface-water inlet.

\section{BENCH 1}

\section{PRE-1974 POND}

Prior to 1974, bench 1 had only one pond, located near the lower end of the bench (fig. 1). Judging from aerial photographs and descriptions by local residents, this pond was more like a dry meadow or at best a shallow ephemeral marsh; it had been ephemeral for at least several decades. The clay bed indicates that it was a pond at times. The 1974-76 disruption revealed pond sediments at least $1.5 \mathrm{~m}$ deep.

The pond was about $65 \mathrm{~m}$ long and nearly $60 \mathrm{~m}$ wide, almost the full width of the landslide. It was oval in shape, the long axis being oriented in the slide direction.

As of July 10, 1974, the pond was about $19 \mathrm{~m}$ downslope from its 1964 location. Most of this shift probably occurred between June 6 and July 10, 1974. The pond held no water in July 1974, and its dry bed showed a few small transverse cracks in one area.

By June 1975, this pond was about $45 \mathrm{~m}$ downslope from its pre-slide (1964) position. The dry upper half of the pond was still intact. The downslope half, however, was demolished as a pond. This lower half was warped upward and included about 10-12 transverse cracks, most of which extended across the full width of the old pond bed.

Total migration of the former pond's leading edge amounted to about $52 \mathrm{~m}$ by August 24, 1975; about $57 \mathrm{~m}$ by November 6, 1975; and about $88 \mathrm{~m}$ by June 1979. (All of these distances were measured to the approximate leading edge of the pond. They do not reflect migration at either of the adjacent left or right borders of the landslide, where the rates could have differed.) The humped lower half of the pond, with its transverse cracks, had been transformed by 1979 into a series of topographic stairsteps that became progressively lower downslide. Some vegetation was established on these stairsteps by 1982.

\section{NEW PONDS}

Sometime between June 12 and August 24, 1975, a new pond formed at the exact site of the pre-slide pond. By May 10, 1976, this new pond was well developed and occupied virtually the entire $70-\mathrm{m}$ width of the slide. In the direction of sliding, the pond measured about $60 \mathrm{~m}$; it had these same dimensions on the date of the 1979 flight and in 1982. The pond, called pond 2 in this report, is fed by surface drainage from the head of the landslide (fig. 1). It has two outlets, each controlled by a beaver dam, on its downstream edge.

Between June 12 and August 24, 1975, a new, small pond (only a few meters long) formed at the lower edge of the upwarped lower half of the original pond. This new pond was short-lived, however, as it has not existed since at least May 1976.

\section{RAMP 2}

As near as can be determined from the 1964 and July 1974 aerial photographs, the region called ramp 2 had no ponds prior to the landslide. Several ponds developed between 1974 and 1982, some of which subsequently disappeared. As of 1982, this region had four ponds (ponds 3 to 6 , fig. 1). Only pond 5 was fed by the main surface stream of the landslide; the others either had no apparent source of water or, as with pond 4, were fed by a small surface flow (trickle) that materialized over a distance of several meters a short distance upslope. Turbidity and algal growth varied from pond to pond.

\section{BENCH 2}

Most of the drastic changes in the bench-2 region occurred during the summer of 1975 . These changes included widespread destruction of vegetation (trees), the formation of many parallel transverse ridges of bared earth, and the formation of several ponds. As the slide progressed, the shapes, sizes, and in some instances locations of the new ponds changed with time.

The only pre-1974 pond in this region was located at the site of the present (1982) pond 8. It was about 70 $\mathrm{m}$ long and $25 \mathrm{~m}$ wide, and its long axis was oriented in the slide direction. About half of its bed area was dry at the times of the September 1964 and July 1974 aerial photography. The fate of this pond is described in the following paragraphs. 
Ponds 8-12 are an example of the temporal transformation of a pre-existing pond and the creation of new ponds. The somewhat rectangular pre-1974 pond, or rather its dry bed, actually was stretched longitudinally during the slide movement, so that the pond's downstream edge migrated much farther than its upstream edge. Significant migration of the downstream edge apparently began sometime between July 1974 and June 1975. During that year, it moved about $50 \mathrm{~m}$. Migration accelerated soon after June 1975. By August 24, 1975, the pond bed had become very elongated in the slide direction and had deformed into a roller-coaster topography consisting of three or four transverse humps. By this time, water had occupied two of the troughs between humps, as new and separate ponds. The two ponds were about $50 \mathrm{~m}$ and $37 \mathrm{~m}$ long, respectively, and the landslide in this area was about $230 \mathrm{~m}$ wide. Pond width was only about $5-10 \mathrm{~m}$. In addition, the surface streamlet from the head of the slide continued to supply water to the somewhat flat area where the former pond had been, so that a large, main pond persisted at this site.

Elongation of the former pond bed continued during the fall of 1975. By November 1975, the lower edge of the old bed had moved another $125 \mathrm{~m}$ from its June 1975 location, for an average migration rate of at least $25 \mathrm{~m} / \mathrm{mo}$ (nearly $1 \mathrm{~m} / \mathrm{d}$ ) during this 5 -mo period.

By May 1976 (about 1-2 yr after the landslide began disrupting the area), three more ponds had evolved between the two that had just appeared and the main pond tens of meters upstream, making six ponds in this local area. Elongation of the former pond bed had slowed significantly as of this time. During the following $3 \mathrm{yr}$, little additional migration or elongation occurred, and as of 1979 , the old pond bed was about $165 \mathrm{~m}$ long or nearly $21 / 2$ times its pre-1974 length. By 1979 , the new pond farthest down the slide had withered to little more than a puddle, and as of 1982 , it no longer existed.

The 1982 situation then showed five ponds in the area. All of these were in the stretched-out zone of the original pond bed. The main pond (pond 8), farthest up the slide, was oval-shaped and was about $80 \mathrm{~m}$ long by $70 \mathrm{~m}$ wide, with its long axis parallel to the slide direction (figs. 1, 4). The other four ponds (ponds 9-12) occurred in troughs formed by transverse ridges and therefore were much narrower than they were long. Pond 9 was an estimated $60 \mathrm{~m}$ long, $13 \mathrm{~m}$ wide, and $1.5 \mathrm{~m}$ deep. It was fed by surface flow from the main pond, pond 8 . Pond 10 (fig. 4) was about $80 \mathrm{~m}$ long, $20 \mathrm{~m}$ wide, and $2 \mathrm{~m}$ deep and was fed by surface drainage from pond 9 . Curiously, surface drainage from pond 10 ran off to the west side of the landslide, and the last two ponds in the group (ponds 11 and 12) had no apparent surface-water inflow or outflow. Pond 11 was about $25 \mathrm{~m}$ long, $5 \mathrm{~m}$ wide, and $1 \mathrm{~m}$ deep; pond 12 was an estimated $60 \mathrm{~m}$ long, $10 \mathrm{~m}$
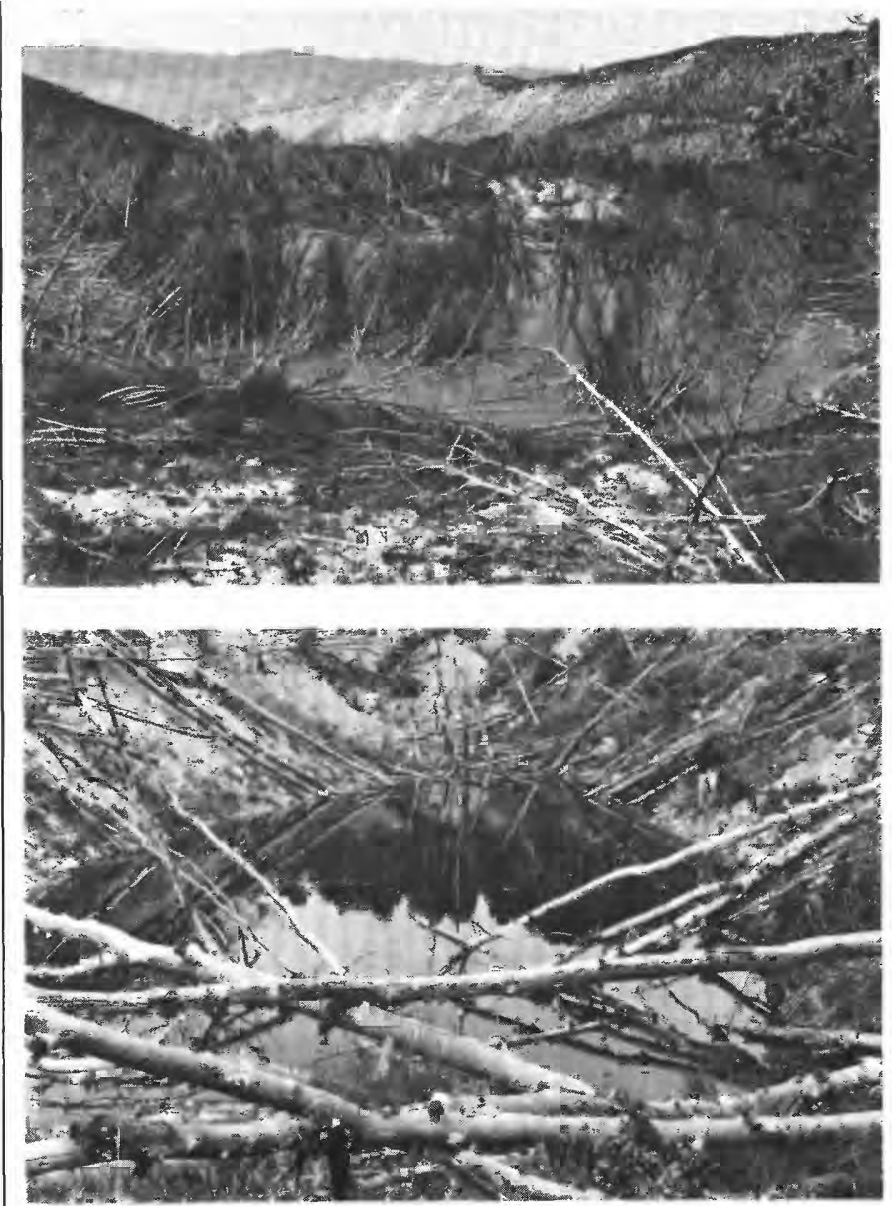

Figure 4.-Pond 8 (upper photograph, looking downslide, July 1982) and pond 10 (lower photograph, looking perpendicular to slide direction, September 1982).

wide, and $2.5 \mathrm{~m}$ deep. Pond 11 had no algae or other plants, whereas pond 12 had heavy algal growth. Also of interest was the water level in the ponds; the levels in the isolated ponds 11 and 12 were about $5-10 \mathrm{~m}$ higher than the level in pond 10 but a bit lower than that of ponds 8 and 9. Therefore, some type of groundwater connection from higher on the slide probably maintained ponds 11 and 12 .

Bench 2 as of 1982 also had three ponds along its western side, and none of these existed prior to 1974 . One of the three, pond 13, was estimated from 1979 aerial photographs and onsite inspection to be nearly $150 \mathrm{~m}$ long and was probably the longest pond on the landslide.

\section{RAMP 3}

Prior to 1974, ramp 3 had just one pond, about $12 \mathrm{~m}$ in diameter and nearly circular, located at the upper 
boundary of the ramp. This pond had not undergone any significant migration or distortion as of July 10 , 1974. However, it had migrated about $40 \mathrm{~m}$ by June 1975 and $80 \mathrm{~m}$ by September 1, 1975. As of the latter date, the landslide was so disrupted on the surface that this small pond became unidentifiable on subsequent aerial photographs. It actually had ceased being a pond even before this date.

Two ponds ( 15 and 16 ) were created by the landslide and occupy topographic lows behind transverse ridges. Neither had any apparent outflow in 1982. Pond 15, about $30 \mathrm{~m}$ long and $2 \mathrm{~m}$ wide, had no visible source of water. Pond 16 , also about $30 \mathrm{~m}$ long but $20 \mathrm{~m}$ wide, received water via surface-flow trickles at each end. Both ponds had some algae.

\section{BENCH 3}

This region also had but one pond prior to 1974 , an ephemeral one about $25 \mathrm{~m}$ long in hummocky terrain at the upper border of the region. The pond was demolished by the landslide sometime between June 12 and August 24, 1975.

Eight new ponds appeared as a result of the landslide (fig. 1). Three of these (ponds 17,23 , and 24) were in the surface-water drainage system; the others had no evident source of water or outflow. Pond 22 (fig. 5), one of the latter group, was adjacent to the stream-fed pond 23 (fig. 5) but was topographically many meters higher. Again, the question arises as to what maintains some of the closed ponds on the landslide.

\section{RAMP 4}

The hummocky terrain of ramp 4 included four ponds before 1974. As with the pre-1974 ponds of bench 3 and ramp 3, none of these was in the surface-water drainage system. Two of them, oval in shape and about 10-15 m long, were near the east edge of the slide. The other two, one about $15 \mathrm{~m}$ long and the other much smaller, were located in the center of the landslide at the upper boundary of the ramp. All of these ponds were present as of June 12,1975 , but were virtually obliterated sometime prior to August 24 of that year.

Of the 20 new ponds that the landslide created on ramp 4, virtually none formed as early as November 1975. In fact, only a few of them, such as ponds 35 and 44, are visible on the May 1976 aerial photographs. All of them, however, can be seen on the 1979 photographs. Thus, the general period of pond formation in this region occurred sometime from May 1976 to June 1979. Because most of the landslide movement occurred
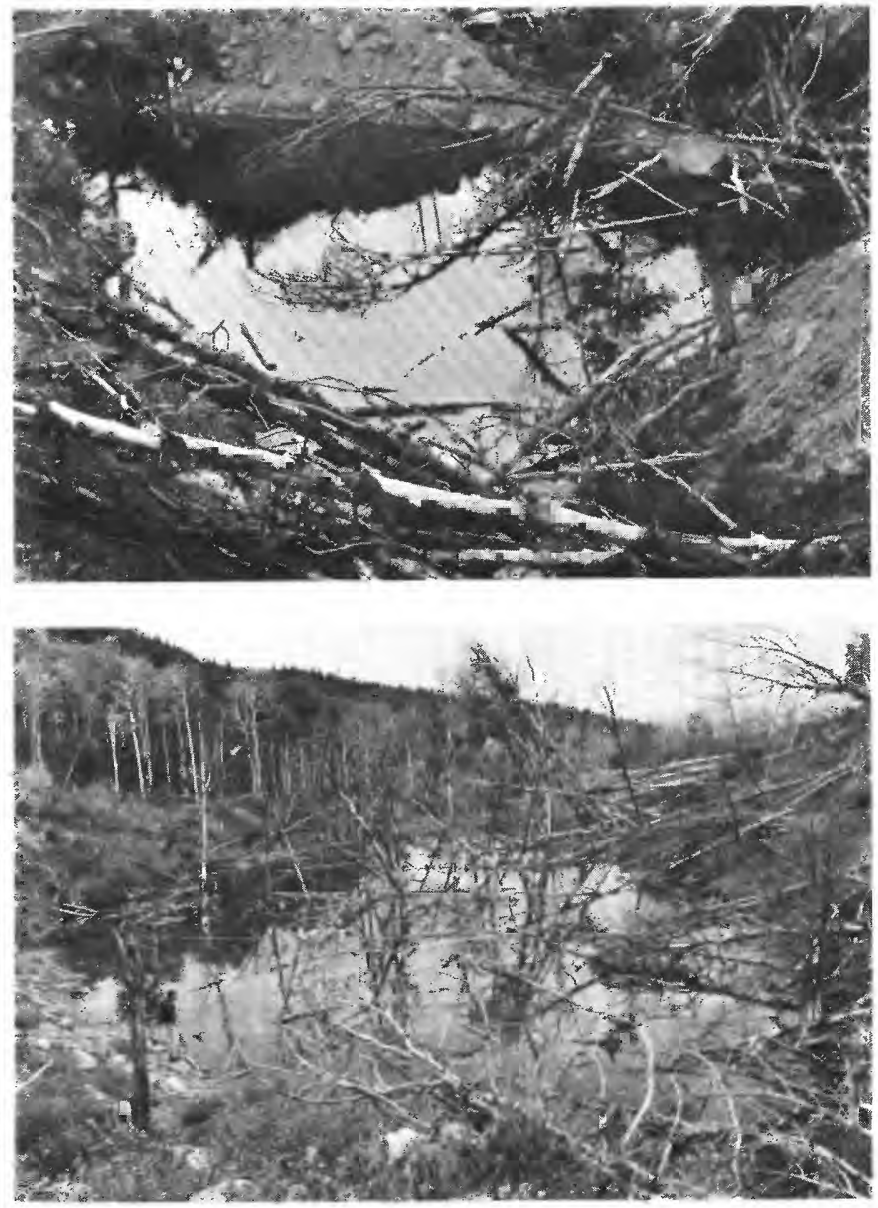

FIGURE 5.-Ponds 22 (upper photograph) and 23 (lower photograph), September 1982. Pond 22 is a closed pond but topographically is several meters higher than the nearby pond 23 , an open pond.

during mid- to late-1975, there was a time lag of about 1-3 yr after the slide activity before water filled various depressions to form ponds in this region. Four of these post-slide ponds are shown in figure 6 .

Most of the new ponds had no apparent inflow or outflow. Many of them probably received water by way of overland flow during storms. Even so, it is questionable whether this would have been enough to maintain water in the ponds. Ground water also could have been a possible supply source.

\section{BENCH 4}

Bench 4 contains Cottonwood Reservoir, the most prominent pre-1974 pond. The only other feature on this bench that might have been classified as a pond before 1974 was a small boggy depression about halfway between Cottonwood Reservoir and the west 

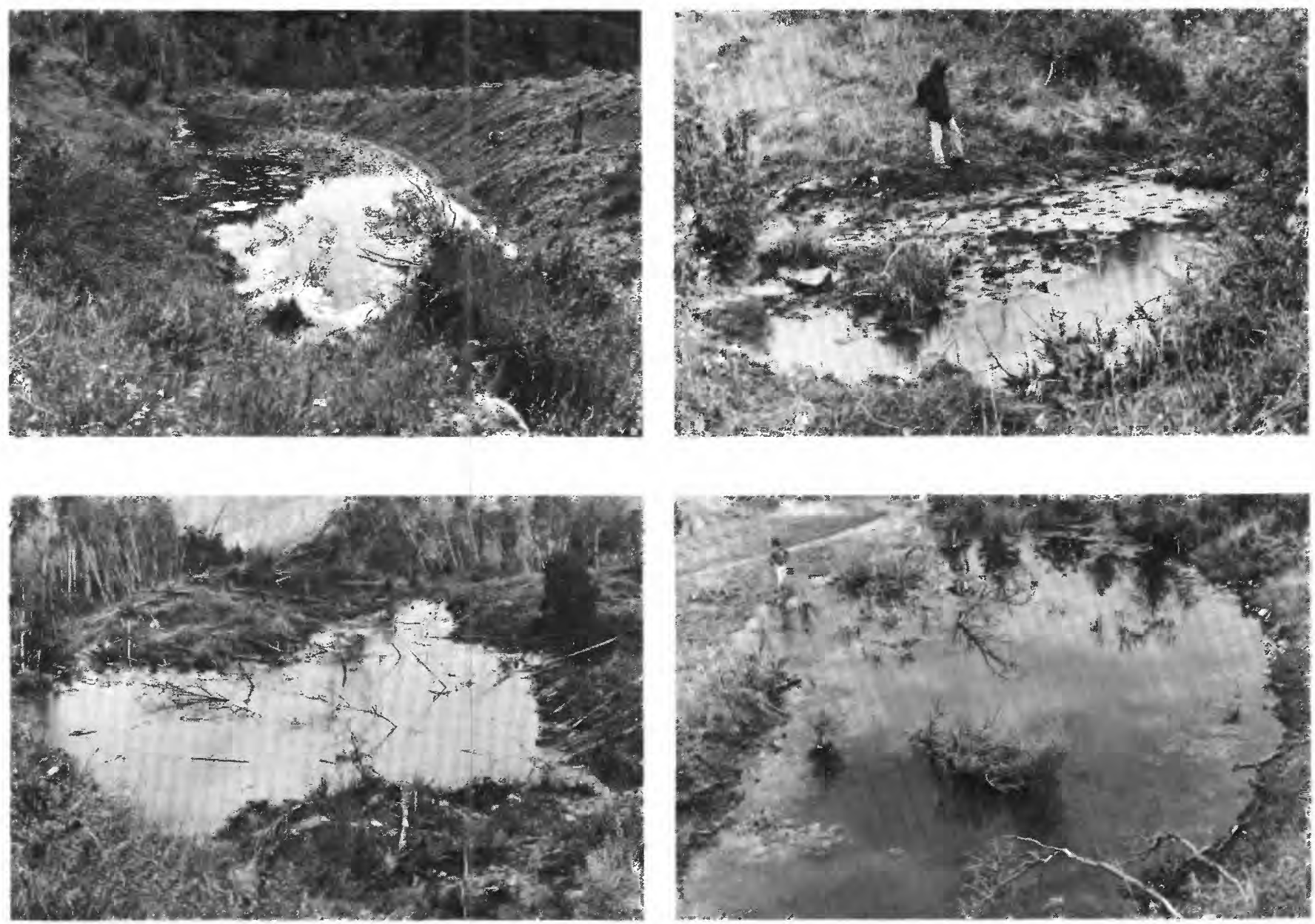

Figure 6.-Representative ponds of ramp 4: pond 25 (upper left), 35 (upper right), 37 (lower left), and 44 (lower right). Photographs taken September 1982 except that of pond 25, which was taken July 1982.

edge of the slide (fig. 1). This boggy area was disrupted substantially by the landslide.

Cottonwood Reservoir first showed visible signs of distortion on the aerial photographs of August 24, 1975. By this date, in addition to some warping of the reservoir bed, transverse cracks were evident in the downslope wall of the reservoir. By September 19, 1975 (nearly 4 weeks later), these cracks had proliferated, and many were several meters deep. By November 6 , the original plan-view shape of the reservoir was very deformed. About two-thirds of the original bed (the downslide part) was upwarped considerably, much of it to the point of being higher than adjacent terrain. It also was dissected by innumerable small cracks. The smaller upslide part remained a depression and by May 1976 had acquired some water again. This remained a pond from that time until at least 1982 (fig. 7). On the other hand, the exposed part of the former bed of the

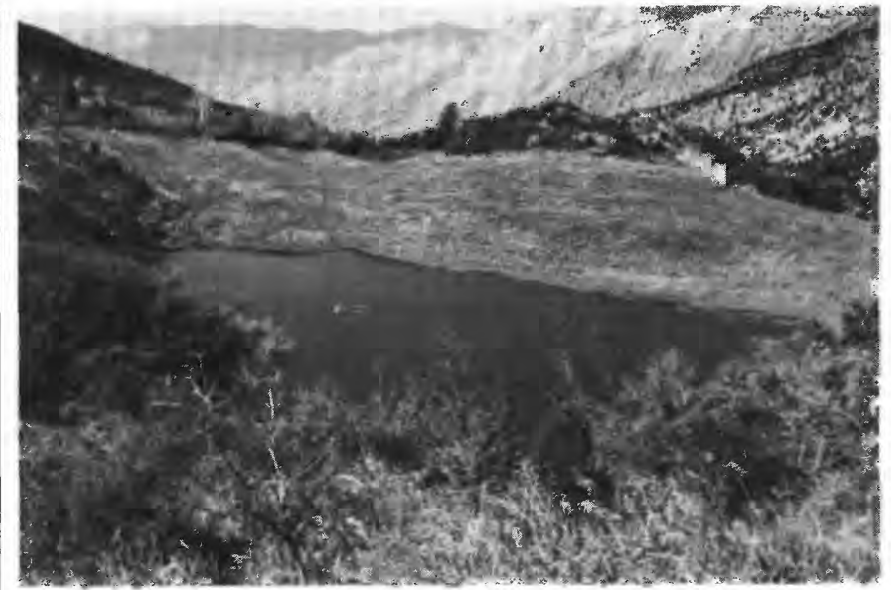

Figure 7.-Downslide view of pond 45 , the post-1976 remains of Cottonwood Reservoir, October 1982. Lightly vegetated area covering entire width of photograph along far edge of pond is exposed bed of former reservoir. 
reservoir in 1982 was part of the landslide surface; even by 1979 it already had some vegetation. Water in 1982 entered the pond via surface seepage from up the slide; there was no surface outflow at normal water levels.

\section{FOOT}

Before 1974, the landslide foot had but one pond, and even that one seems to have held water only on rare occasions. This pond was on the slope of the foot in the drainageway from Cottonwood Reservoir to Manti Creek. The sandy depression was reduced in size and somewhat deformed by the slide. It filled with water sometime between May 1976 and June 1979, is called pond 55 , and is about $15 \mathrm{~m}$ long by $6 \mathrm{~m}$ wide (fig. 8 ).

Approximately 15 additional ponds were created in the landslide foot as a result of the slide movement (fig. 1). Nearly all of these in 1982 were in a topographically lower area in the eastern part of the foot. Some of these ponds received water from seeps and surface trickles on the sloping part of the foot. Other ponds had no visible source of water; ground water and storm runoff were possibilities. In many cases, the shapes and perimeters of the ponds were quite irregular.

\section{CHRONOLOGY OF POND APPEARANCE}

An approximate formation date was estimated for nearly all new ponds, based on aerial-photograph analysis. No great accuracy can be claimed for these dates. Generally, a post-1974 pond could be identified on one set of aerial photographs but did not appear on those of the preceding flight. Therefore, the birth of such a pond could be dated at least to the interval between such successive flights. When photographs were taken every few weeks or less, as in mid- to late-1975, the estimated pond-formation dates probably are accurate to within a few weeks. On the other hand, the interpolation required between the May 1976 and June 1979 flights may be in error as much as $2 \mathrm{yr}$. Virtually all of the 63 ponds had formed by June 1979 .

Some ponds changed very little in size and shape after they first appeared on aerial photographs. Others went through a metamorphosis lasting several months or longer, as for example, ponds 8-12, described previously. The number of days needed for any one pond to form could not be determined in most instances.

Each pond's approximate birthdate as a function of distance along the landslide is shown in figure 9, except for the few ponds (nos. 1, 6, 8, 15, 30, 41, and 63) for which a date could not even be estimated. Ponds shown as having appeared 3-5 yr after the June 1974 initiation of slide movement probably did appear during that 2-yr period, but the distribution within the period may not be the same as that indicated in the figure. Also
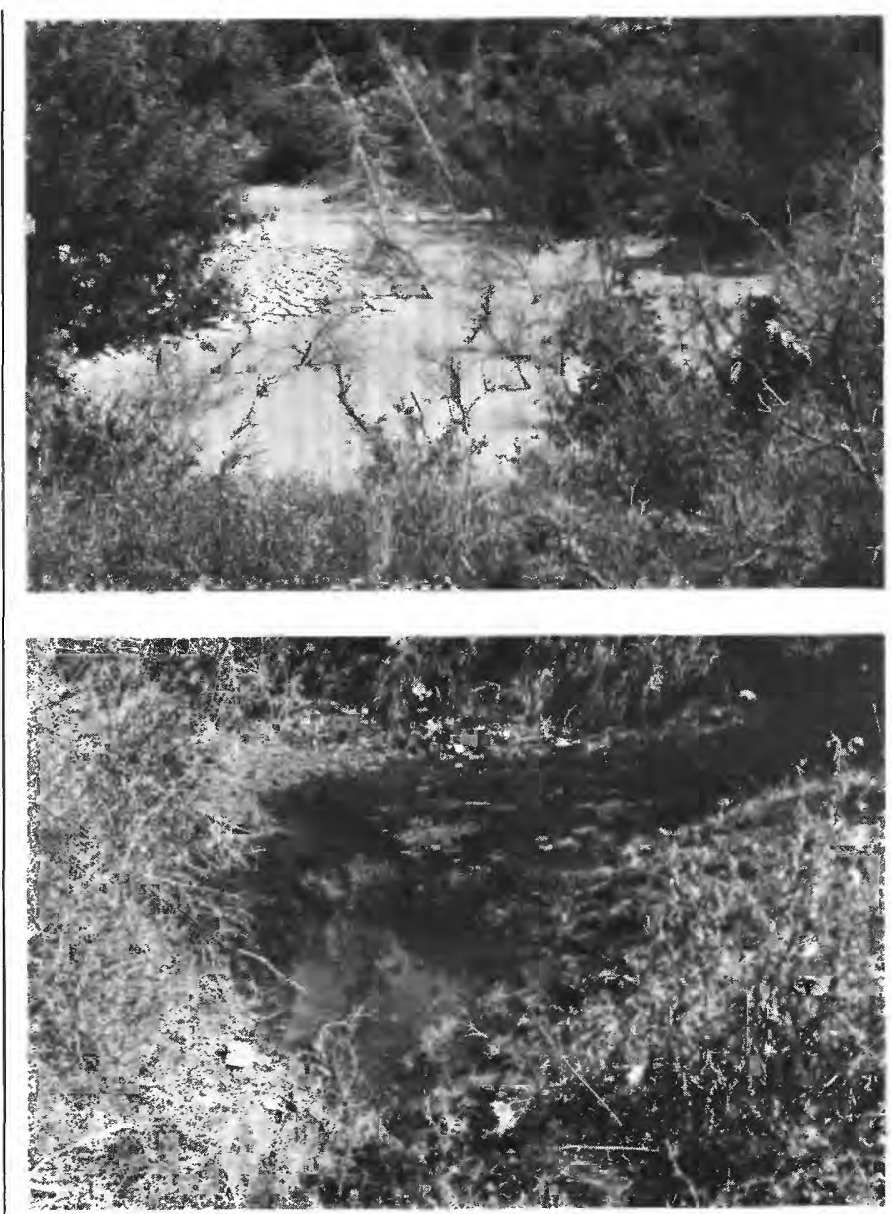

FiGURE 8.-Typical ponds of the foot: pond 50 (upper photograph, July 1982) and pond 55 (lower photograph, October 1982).

shown is a curve representing the propagation of the active front of the landslide. This curve is based on information from Fleming and others (1977) and Olson $(1977,1978)$, and on aerial-photograph analysis done for this report. In spite of the considerable scatter, several tentative conclusions can be drawn:

1. No pond was created until its terrain had been disrupted by the landslide; that is, movement in the upslope regions of the landslide did not hydrologically influence the existence or appearance of ponds in the undisturbed regions downslope from the active front of the landslide.

2. With the exception of pond 8 , which seems to have existed throughout the period of disruption and which therefore is not plotted, there was a time lag of at least 1 year after the failure on June 6, 1974, before any new ponds formed.

3. Comparison of pond-formation dates to the approximate date on which the propagating landslide front passed each pond's location suggests two conclusions: 


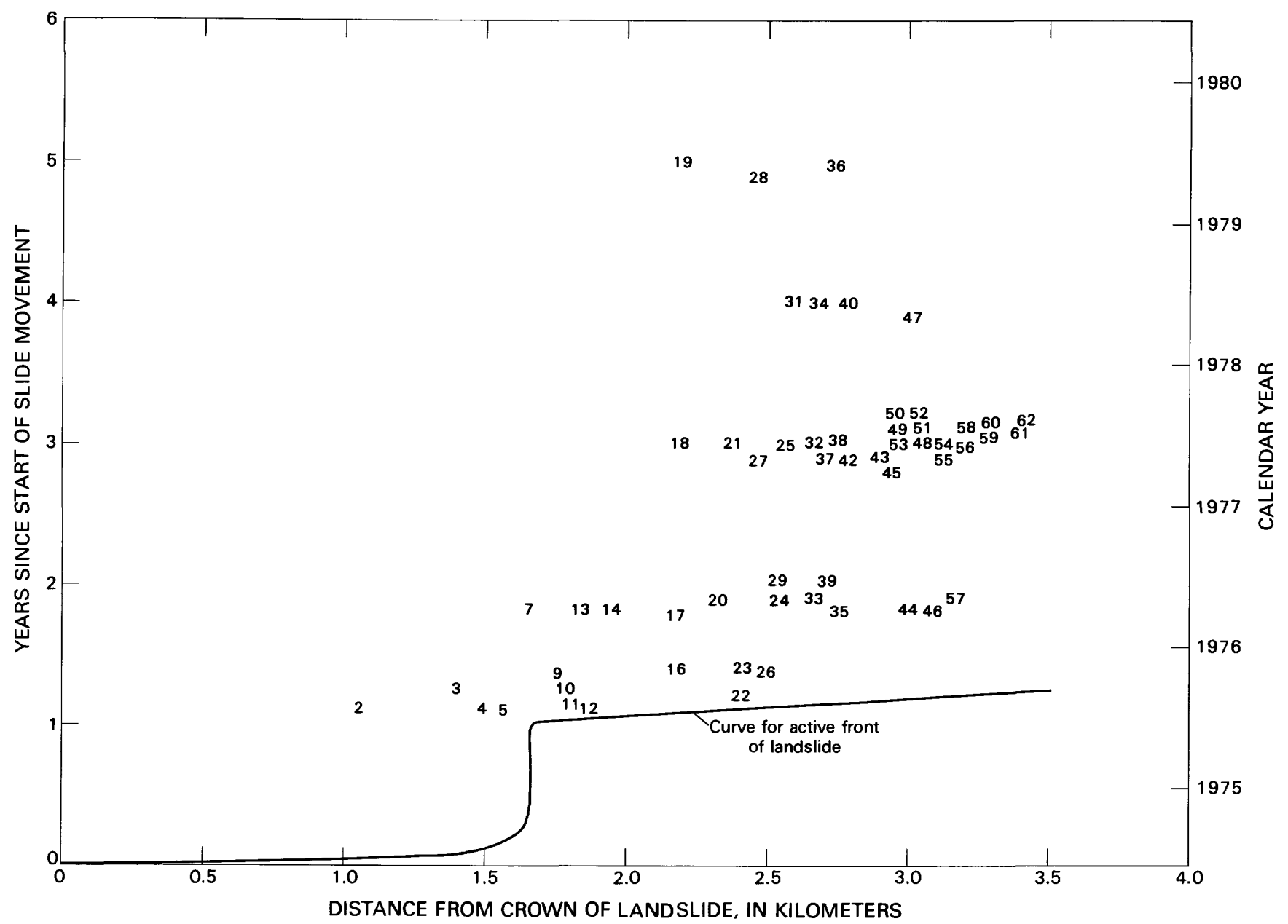

FIGURE 9.-Dates of pond establishment as a function of distance along the landslide. Plotted numbers are pond numbers (fig. 1).

a. Ponds in the upslope half of the slide, ponds 2 through 14, all formed within about 1 year after the active front passed their area (about 1-2 yr after the June 6,1974, initial failure); and

b. Ponds in the lower half of the landslide appeared 0-4 yr after their area was first invaded by the slide (about 1-5 yr after the landslide began at the crown).

It is possible, but in my view not too probable, that sample size may have influenced these last two observations; the upslope half of the landslide has considerably fewer ponds than the lower half.

4. There is a slight tendency for open ponds (those fed by main surface drainage) to form sooner than closed ponds at a given distance down the slide.

\section{POND SEDIMENTS AS TOOLS FOR DATING LANDSLIDE ACTIVITY}

The formation of so many ponds attributable to landslide movement leads to the possibility of interesting and practical interpretations of past landslide activity in any area where ponds have formed on landslide surfaces. As a preliminary step, other contemporary landslides need to be studied to determine whether such pond formation is a widespread and general phenomenon on landslides of this type or is instead an aspect unique to the Manti landslide. Overall slope, speed of land movement, lithology, and other features might have some direct or indirect influence on post-slide pond formation.

A variety of methods is available for dating lakes and ponds (Winter and Wright, 1977). These methods generally involve analyzing minerals, biological matter, and chemicals from cores of the bed sediments. The accuracy of each method varies not only with its state of development, but also (for most methods) with location on the continent, previous regional correlations, climate, and other factors.

Application of one or more of the dating methods to 
various ponds on a landslide surface could establish both the relative and absolute ages of the ponds. When a number of ponds on a landslide seem to have been formed at about the same time, such a date might represent a time of significant slide movement, if the groupformation phenomenon on the Manti landslide is commonplace. Other dating methods, such as tree-ring analysis, also might be used as evidence in some instances.

Preliminary work on dating landslide occurrence using pond sediments has been done. Adam (1975) analyzed pollen and radiocarbon dates from the sediments of a landslide pond in California. He established the date of pond formation and the dates of subsequent movement of the landslide. He also made some regional climatic interpretations. Cloud (1981) and colleagues are developing a relative-dating method based on the areal extent of sedimentation within surface depressions (generally not ponds) formed by landslides.

Dating landslide movement by pond analysis is based on the assumption that landsliding causes ponds to form. Should this assumption and general approach prove workable, additional possibilities arise. More than one movement might be identified for a landslide by determining the dates of formation of various ponds. Certain deductions also might be made in regard to type of landslide movement, such as translational versus flowing movement. In some cases, the entire history of a given landslide's activity conceivably might be reconstructed. Finally, the same principles could be applied on a regional basis to compare the history of various landslides.

In addition to scientific interest, dating of past landslide activity would have important practical applications. Knowledge of the approximate frequency of previous landslide activity in an area would be useful to planners and land developers, foresters, farmers, and others involved in land use.

\section{MANTI CREEK}

\section{SEDIMENT INTRODUCTION FROM THE LANDSLIDE}

\section{METHODS OF SEDIMENT INTRODUCTION}

Olson $(1975$, p. 5$)$ defined three ways in which landslide material entered Manti Creek at the toe of the slide. In the first method, individual particles fell or rolled from the landslide mass into the creek. The second possibility was for masses of as much as about $4 \mathrm{~m}^{3}$ to dislodge from the slide mass and to disaggregate in flight before hitting the water. In a third method, an entire wall section of the oversteepened landslide mass simply slumped into the creek (fig. 10, September photograph).

Sediment introduced by these methods ordinarily did not block Manti Creek completely, although several small blockages of the creek, lasting as long as 5 or 6 min, did occur during September 1975. As of the end of September 1975, the largest known mass to enter the channel was about $1,900 \mathrm{~m}^{3}$ (September 4, 1975; Olson, 1975 , p. 5).

\section{RATE OF TOE MOVEMENT}

Onsite observations and aerial-photograph measurements indicate that movement at the toe of the Manti landslide did not begin until late summer of 1975 , even though the upper regions had moved considerably during 1974. Cracks in the toe were first noticed on June 21, 1975 (Olson, 1978, p. 26).

The rate of toe movement into the Manti Creek slide reach was measured from time-sequential aerial photographs by Olson (1978, p. 26-28). The upstream or first one-fourth of the creek's slide reach is bordered on the left side by a flat or terrace that was pushed streamward. Most of the movement in this subreach occurred between June 1975 and the end of November 1975. Streamward movement averaged about $0.2 \mathrm{~m} / \mathrm{d}$ from June 12 to September 19, 1975; $1.2 \mathrm{~m} / \mathrm{d}$ from September 19 to November 6, 1975; and about $0.1 \mathrm{~m} / \mathrm{d}$ (a total of about $3 \mathrm{~m}$ ) during the rest of November 1975 .

Movement in the second one-fourth of the slide'reach, where the toe of the slide abuts the stream channel, also took place primarily from the end of August through November 1975. The toe in this subreach advanced at an average rate of about $0.3 \mathrm{~m} / \mathrm{d}$ between September 19 and the end of November 1975.

Along the western or downstream half of the Manti Creek slide reach, streamward movement of the channel side averaged about $1 \mathrm{~m} / \mathrm{d}$ from September 19 to November 6, 1975. The rate was not constant during this period; it was faster during the last 2 weeks of September and slower after October 1.

\section{TYPE AND SIZES OF SEDIMENT}

The sediment introduced into Manti Creek from the toe of the landslide was not firmly consolidated and ranged from clay to boulders about $4 \mathrm{~m}$ in diameter. The particle size distribution of exposed toe material at cross section 1 is shown in figure 11; cross section 1 is located slightly less than halfway along the slide reach (fig. 1). The plotted distribution is based on a random (grid) 

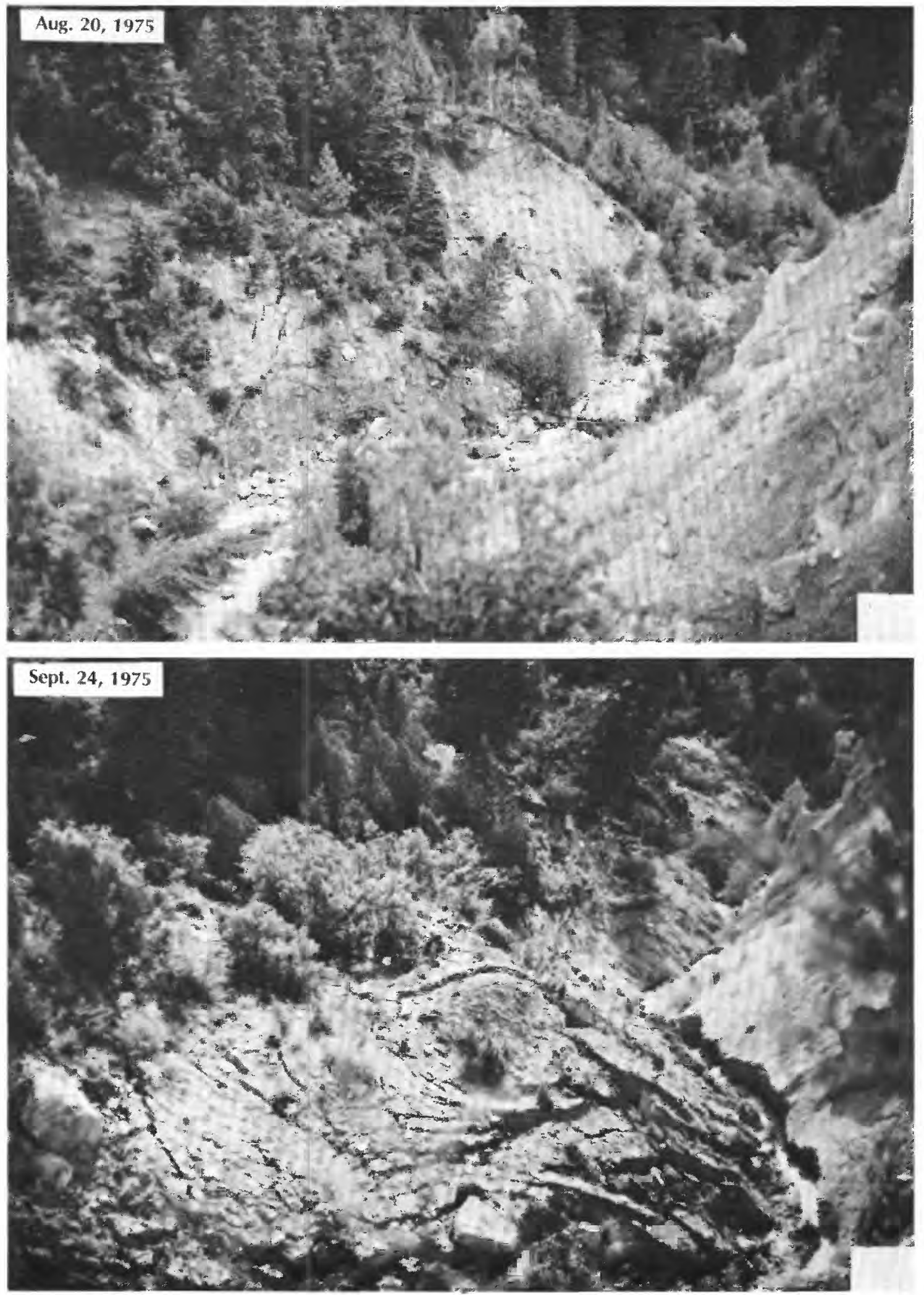

FIGURE 10.-Time-sequential photographs showing sediment introduction at a site in the downstream part of the Manti Creek slide reach, looking downstream. North is to the right. Photographs by Earl P. Olson, U.S. Forest Service. 


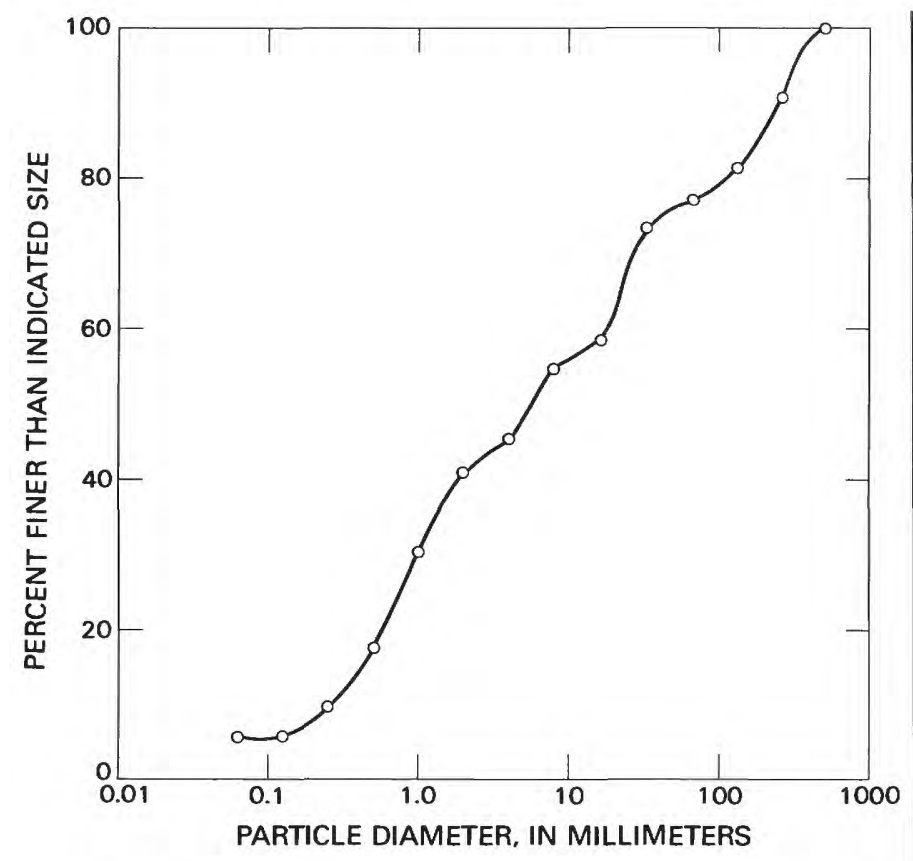

FIGURE 11.-Representative size-frequency distribution of toe sediment, Manti landslide.

sampling, on a number basis, of exposed particles of all sizes. Sediment less than $4 \mathrm{~mm}$ in particle diameter was listed in a single category and subsequently analyzed by sieving; particles greater than $4 \mathrm{~mm}$ in diameter were recorded onsite on a number basis within each size class. The two frequency distributions then were weighted according to their respective proportions of exposed surface area on the deposit and combined into the single frequency distribution shown in figure 11 . The sizes of sediment about $200 \mathrm{~m}$ farther downstream are shown in figure 12.

The frequency distribution (fig. 11) might have been slightly different if another site had been sampled; however, by visual inspection, the toe material is not significantly different from one part of the slide reach to another, and the distribution shown in figure 11 seems to be generally representative. All size classes are present, and about 6 percent of the material is less than $0.062 \mathrm{~mm}$ in diameter.

\section{GENERAL NATURE AND PATTERN OF MANTI CREEK}

From at least 1950 and well into the slide period, Manti Creek flowed in a slightly sinuous, single, welldefined channel of nearly constant width. The bed material, as judged from aerial photographs, seems to

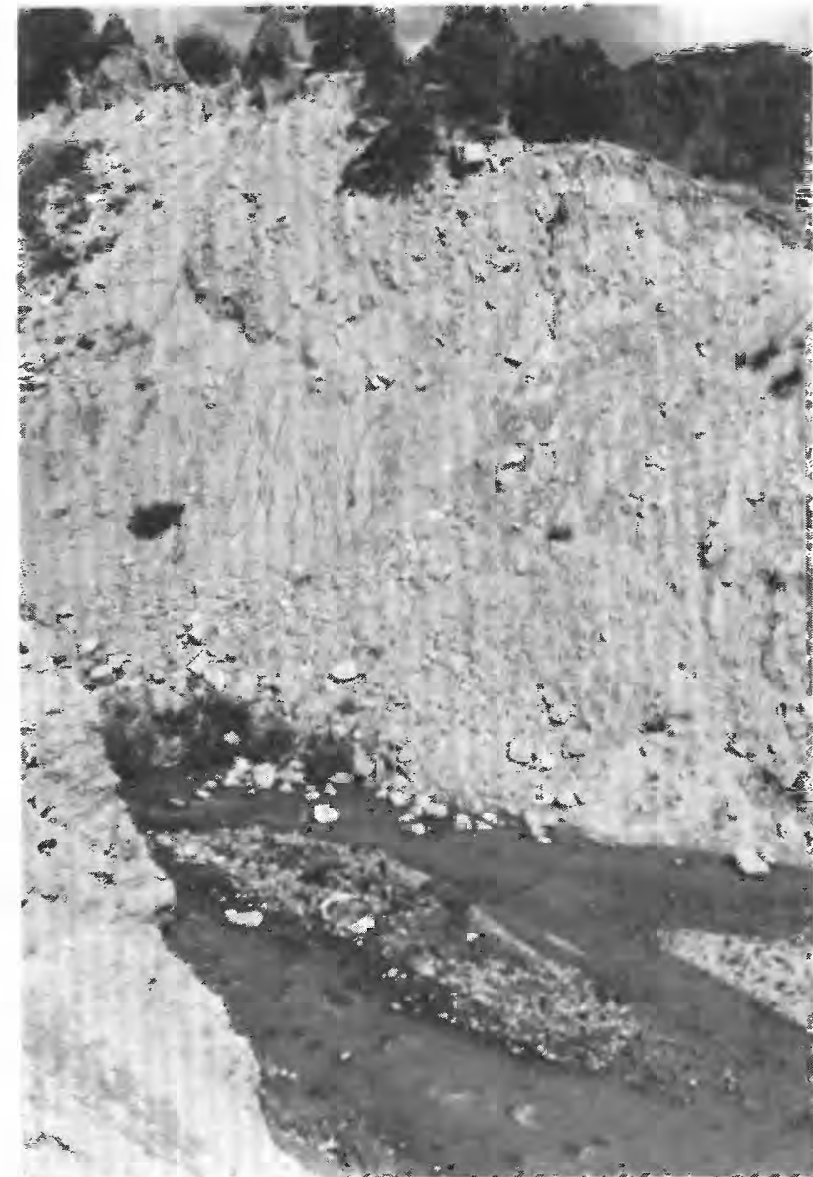

FIGURE 12.-Toe of landslide and Manti Creek about midway along the slide reach, July 1982 . The steep left bank shown here is about $25 \mathrm{~m}$ high.

have been mostly sand and gravel for at least $200 \mathrm{~m}$ upstream from the east edge of the landslide (a reach of relatively flatter gradient). Through most of the slide reach the gradient was quite steep, as will be discussed later in this report, and the bed material was much coarser, with many cobbles and boulders. This general condition lasted until about mid-September 1975.

The September 1, 1975, aerial photographs of the channel show no change from the previous channel except in the downstream half of the slide reach; here the added sediment from the slide produced a somewhat smoother streambed (a greater proportion of finegrained material). In a couple of short subreaches, two separate low-water channels tended to form, instead of the previous single channel. All of these features were even more noticeable and pronounced on the September 19,1975 , photographs. The channel in the affected downstream half of the slide reach also was somewhat narrower by this date. 
A striking transformation took place between midSeptember and early November 1975 . The landslide movement had lengthened the slide reach from a midsummer value of about $730 \mathrm{~m}$ to a November value of about $1,000 \mathrm{~m}$. Nearly all of this increase occurred at the upstream end of the reach. The obvious sediment influx along the reach created two pools, each a few tens of meters long, in the downstream half of the slide reach. These separated the slide reach into three narrow, steep subreaches, hereafter referred to as cascades 1,2 , and 3 (fig. 1). Compared to the earlier, rather uniform width, the pool reaches were somewhat wider and the cascades narrower. The bed of the previously rather smooth upstream section became much rougher. Where particularly large quantities of sediment had slid into the channel at several points in the downstream part of the slide reach, the channel became braided. Amounts of bed aggradation will be discussed in the section entitled "Channel aggradation and longitudinal profiles."

As of the following spring (May 10, 1976), the section upstream from cascade 1 had changed from a single channel to a braided and wider channel. Elsewhere, the channel pattern was not significantly different from that of autumn 1975. By 1979, the upstream braided zone again appeared to be sandy. At the time of the 1982 onsite inspection, the bed material in this subreach ranged from sand to cobbles. Also as of 1979 (and 1982), islands occupied the sites of the two downstream pools (fig. 13). Particle sizes on the islands were primarily cobbles, at least in 1982. The intervening and relatively long cascade subreaches were narrow and steep, had coarser bed material (mainly boulders), and tended to form a single channel (fig. 14). The actual horizontally projected lengths of the cascade reaches in 1982 were $170 \mathrm{~m}$ for cascade $1,74 \mathrm{~m}$ for cascade 2 , and $220 \mathrm{~m}$ for cascade 3 .

\section{CHANNEL CROSS-SECTION GHARACTERISTICS}

General cross-section changes that the landslide caused at the locations of the two measured cross sections are shown in figure 15 . Both sections became narrower and shallower, and the creek was shifted to the right (northward). Cross section 1, located about $200 \mathrm{~m}$ downstream from the start of the 1974 slide reach, did not change as drastically as cross section 2 .

The measurable channel dimensions for the two cross sections at different times are listed in table 1. The dimensions were approximately constant from 1950 through September 19, 1975, but decreased considerably during the following $11 / 2 \mathrm{mo}$. For example, the top width at cross section 1 averaged about $80 \mathrm{~m}$ before the landslide period and about $69 \mathrm{~m}$ afterward.

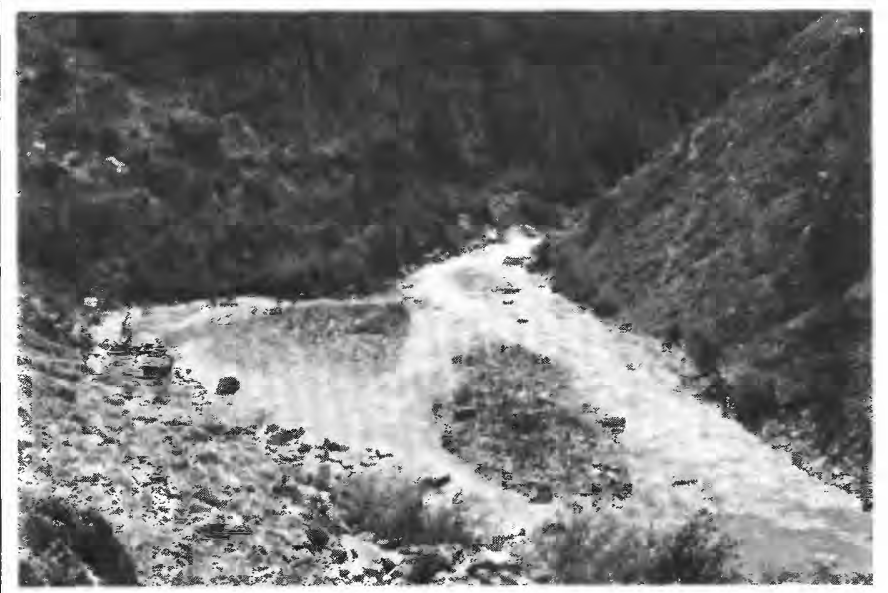

Figure 13.-Downstream view of braided section that separates cascade 1 from cascade 2, July 1982.

Maximum depth at that site was reduced from about $28 \mathrm{~m}$ to about $24 \mathrm{~m}$. Both of these dimensions decreased by about 14 percent, so that the width/depth ratio (about 2.8) remained essentially unchanged. The postslide cross-sectional area (a little more than $700 \mathrm{~m}^{2}$ ) at cross section 1 was only about 60 percent of the preslide area (table 1).

Cross section 2, about $400 \mathrm{~m}$ downstream from the start of the 1974 slide reach, is in a region that received much more landslide sediment than cross section 1 . The post-slide top width at cross section 2 , judging from the plots in figure 15, was not more than half the pre-slide width. Using the right banktop as the datum for measuring channel depth, the maximum depth decreased from about $35 \mathrm{~m}$ to about $11 \mathrm{~m}$ because of the landslide (table 1).

The changes described for the two specific cross sections typify the changes that occurred throughout most of the slide reach. Several of these general changes will be discussed in the next part of this report.

\section{LATERAL DISPLACEMENT}

One of the drastic landslide-induced changes that Manti Creek underwent throughout most of the slide reach was a lateral displacement to the north (figs. 10 and 16). From August 1950 through September 1, 1975 (and probably earlier), according to plan-view trace overlays made from the aerial photographs, the channel remained in the same location. During the period from September 1 to September 19, 1975, sideward (northward) displacement of several meters occurred 
(fig. 10) in a zone about $200 \mathrm{~m}$ long beginning at cross section 2; elsewhere the channel position remained unchanged. The lateral offset was the simple result of sediment coming into the channel along the left (south) side.

A substantial displacement occurred during the 11/2 months from September 19 to November 6, 1975 (fig. 16); the affected reach lengthened to about $1,000 \mathrm{~m}$. Planimetering on trace overlays of the area of offset and dividing by the associated length of channel yield an average lateral displacement of about $15 \mathrm{~m}$. The more significant changes occurred in the downstream half of the reach, where the maximum offset was about $33 \mathrm{~m}$. A short section, about $60 \mathrm{~m}$ long, in the upstream half of the slide reach did not shift at all.

No significant change in channel location occurred between November 1975 and early May 1976. However, the 1979 photographs show a possible continued northward displacement, relatively minor in magnitude, throughout most of the slide reach. One exception is a short zone just downstream from cross section 2 , where bulldozers relocated the channel several meters back toward the landslide (southward).

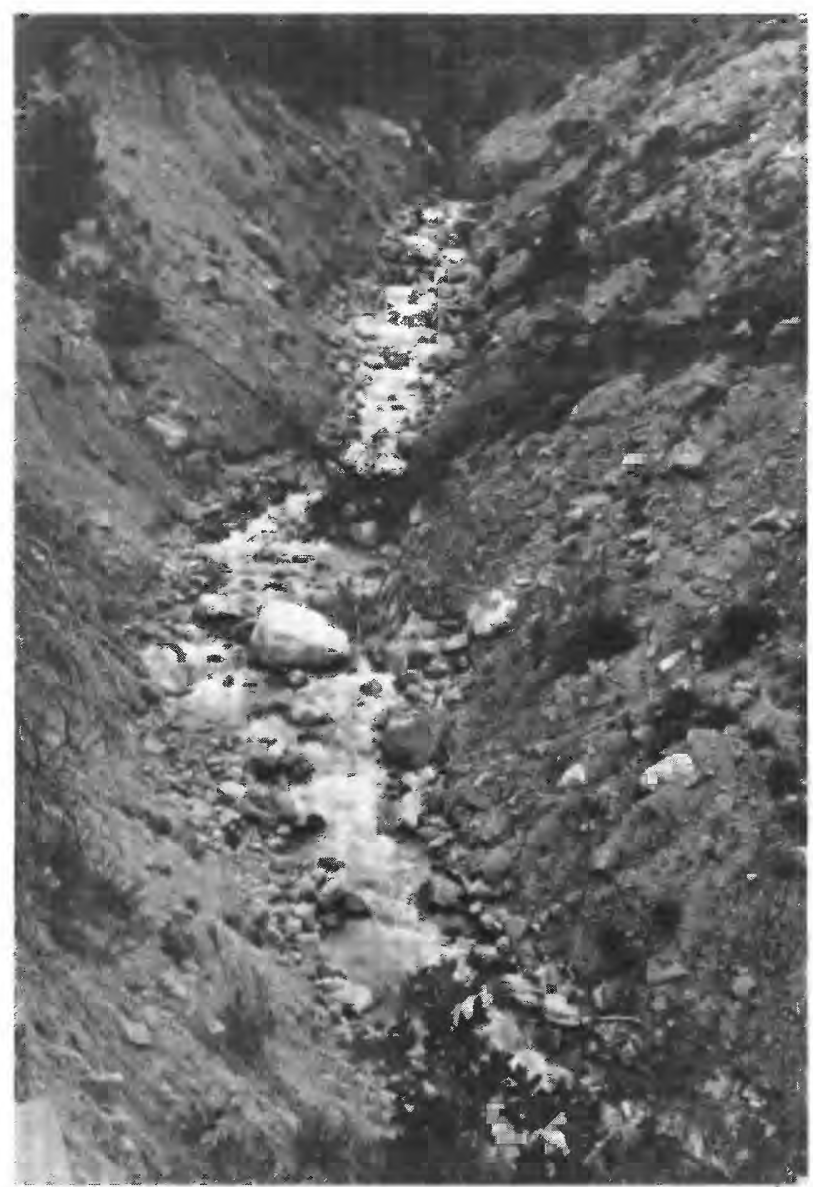

\section{AVERAGE WIDTH OF STREAMBED}

Within the original 730-m-long slide reach, the channel bed was about 7-9 m wide through September 1, 1975. By September 19, 1975, however, the bed in cascade subreaches was, in places, as narrow as $2 \mathrm{~m}$ or less (fig. 10), even though the average bed width for the cascade sections as a whole was about $5 \mathrm{~m}$. The bed width, therefore, was the first of the measured channel features to show a noticeable reaction to the landslide, within the range of measuring capability on the available photographs.

The average bed width in cascade subreaches was about $4 \mathrm{~m}$ in November 1975 , and it still was narrow (about $5 \mathrm{~m}$ ) the following spring (May 1976). By 1979, except for the three relatively short, braided subreaches, it had widened to its initial 7- to 9-m range.

\section{CHANNEL AGGRADATION AND LONGITUDINAL PROFILES}

The channel elevation at any location and the longitudinal profile of the Manti Creek slide reach changed

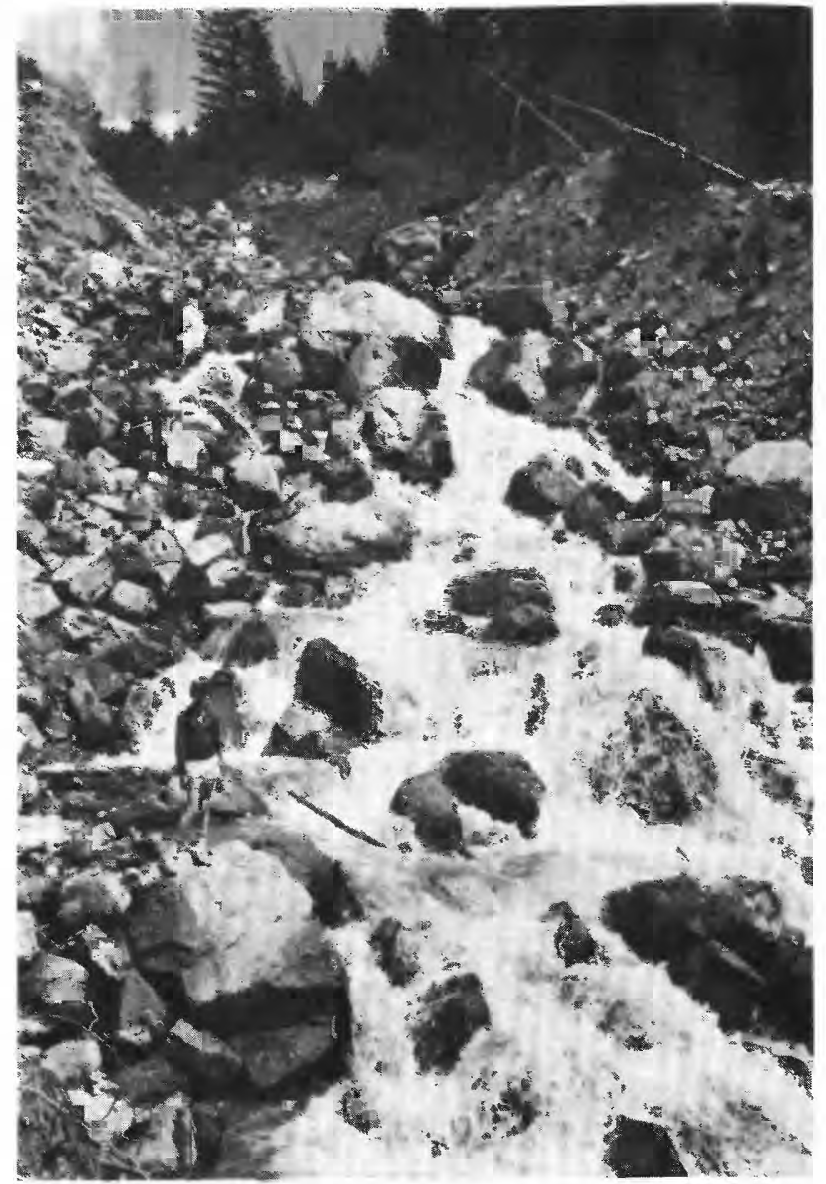

Figure 14.-Upstream views of parts of cascade 1 (left photograph) and cascade 3 (right photograph), July 1982. 

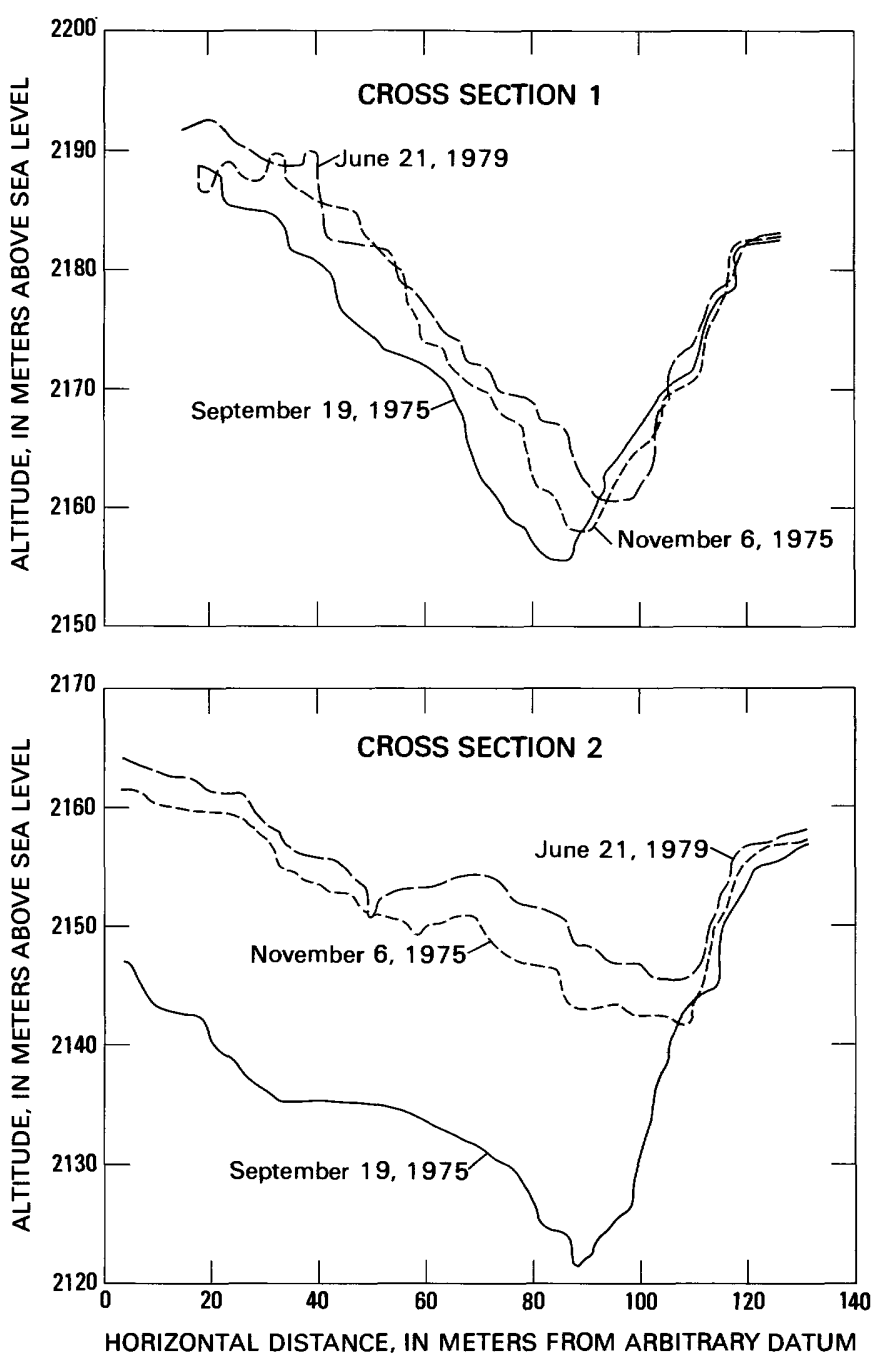

FiguRE 15.-Cross-sectional changes on Manti Creek at selected times. Landslide encroached from left side. Locations of cross sections are shown in figures 1 and 16.

remarkably as a result of the 1975 landslide. According to profiles plotted from aerial photographs, no significant change occurred from August 1950 through September 19, 1975. (This does not mean that the slide movement did not inject sediment into the channel prior to September 19, 1975; it means only that any such quantities did not aggrade the channel by more than about a meter, if at all.) However, the profile of November 6, 1975, showed considerable aggradation, especially in the downstream half of the slide reach (fig. 17). The previously rather uniform slope of the channel (about $0.14 \mathrm{~m} / \mathrm{m}$ ) was broken into a system of alternating cascades and pools, as already described. The average aggradation for the original $730-\mathrm{m}$-long September 19,1975 , slide reach was about $11 \mathrm{~m} / \mathrm{m}$ of channel length. At selected sites along the channel, the aggradation ranged from insignificant amounts to as much as about $31 \mathrm{~m}$.

During the following 6 months, to May 1976, the three cascade subreaches remained unchanged; however, sediment accumulated in the two pools and in the relatively flatter reach upstream from cascade 1 , giving these three zones a braided character. The additional aggradation averaged about $1 \mathrm{~m}$ in the first braided zone, $2 \mathrm{~m}$ in the second braided zone, and $3 \mathrm{~m}$ in the third braided zone (in downstream order). As a result of the additional fill, the aggradation within the original slide reach after September 19, 1975, averaged about $12.6 \mathrm{~m} / \mathrm{m}$ of channel length, and the maximum fill at any one point was about $35 \mathrm{~m}$. The reach affected by the landslide was actually about $1,000 \mathrm{~m}$ long, and the aggradation along this extended reach averaged about $10 \mathrm{~m} / \mathrm{m}$ of channel length. This aggradation was not distributed uniformly along the reach; it was smallest at the upstream end and generally increased with distance to a point about $200 \mathrm{~m}$ upstream from the lower end of the slide reach.

Taking the aggraded area as planimetered between longitudinal profiles and multiplying by the September 19,1975 , average bed width of $5 \mathrm{~m}$ gives a conservatively estimated volume of about $50,000 \mathrm{~m}^{3}$ of sediment pushed laterally into the channel by the landslide between September 19, 1975, and May 10, 1976. Such an estimate is especially conservative in that it does not take into account any sediment eroded by the stream between the measuring dates. (The flow fluctuates with the seasons, and discharges are relatively large during May and June.)

The June 1979 profile (fig. 17) showed minor additional changes; together these changes suggest a little additional aggradation and a slight tendency for the channel profile to become more regular; that is, to eliminate the particularly high and low spots along the reach. These trends continued to an even lesser extent for the next 3 years, as indicated by the onsite-measured 1982 profile (not shown on fig. 17). As of 1982, the slope through cascade 1 averaged about $0.10 \mathrm{~m} / \mathrm{m}$, cascade 2 was about $0.088 \mathrm{~m} / \mathrm{m}$, and cascade 3 was about $0.23 \cdot \mathrm{m} / \mathrm{m}$.

Average total (cumulative) channel aggradation per meter of channel length along the original $730-\mathrm{m}$-long slide reach was $14.4 \mathrm{~m}$ as of 1979 and $14.6 \mathrm{~m}$ by 1982 . The four values of cumulative aggradation at different times show a plausible trend of aggradation with time (fig. 18). According to this plot, aggradation took place very rapidly immediately after the slide began pushing sediment into the channel. This rapid accumulation continued for several months, then slowed significantly, becoming asymptotic toward some limiting amount. The plot of the points approximates a hyperbola of the form 
TABLE 1.-Manti Creek channel dimensions as measured from aerial photographs [All 1982 data measured in field]

\begin{tabular}{|c|c|c|c|c|c|}
\hline \multirow[b]{2}{*}{$\begin{array}{c}\text { Date of } \\
\text { aerial } \\
\text { photograph }\end{array}$} & \multicolumn{4}{|c|}{ Cross section 1} & \multirow{2}{*}{$\begin{array}{c}\text { Cross } \\
\text { section } \\
2 \\
\\
\text { Maximum } \\
\text { depth } \\
\text { (m) }\end{array}$} \\
\hline & $\begin{array}{l}\text { Top } \\
\text { width } \\
\text { (m) }\end{array}$ & $\begin{array}{l}\text { Maximum } \\
\text { depth } \\
(\mathrm{m})\end{array}$ & $\begin{array}{l}\text { Width/ } \\
\text { depth } \\
\text { ratio }\end{array}$ & $\begin{array}{l}\text { Channel } \\
\text { cross- } \\
\text { sectional } \\
\text { area } \\
\left(\mathrm{m}^{2}\right)\end{array}$ & \\
\hline Aug. 9, 1950 & 81 & 28 & 2.9 & 1300 & 38 \\
\hline Sept. 11,1964 & 82 & 27 & 3.0 & 1340 & 35 \\
\hline July 10,1974 & 81 & 27 & 3.0 & 1270 & 34 \\
\hline June 12,1975 & 81 & 29 & 2.8 & 1280 & 35 \\
\hline Aug. 24,1975 & 78 & 28 & 2.8 & 1220 & 35 \\
\hline Sept. 1,1975 & 81 & 29 & 2.8 & 1290 & 37 \\
\hline Sept. 19,1975 & 78 & 29 & 2.7 & 1210 & 34 \\
\hline Nov. 6,1975 & 66 & 25 & 2.6 & 740 & 15 \\
\hline May 10,1976 & 71 & 24 & 3.0 & 720 & 11 \\
\hline June 21,1979 & 68 & 24 & 2.8 & 730 & 11 \\
\hline July 28,1982 & 70 & 21 & 3.3 & 910 & 11 \\
\hline
\end{tabular}

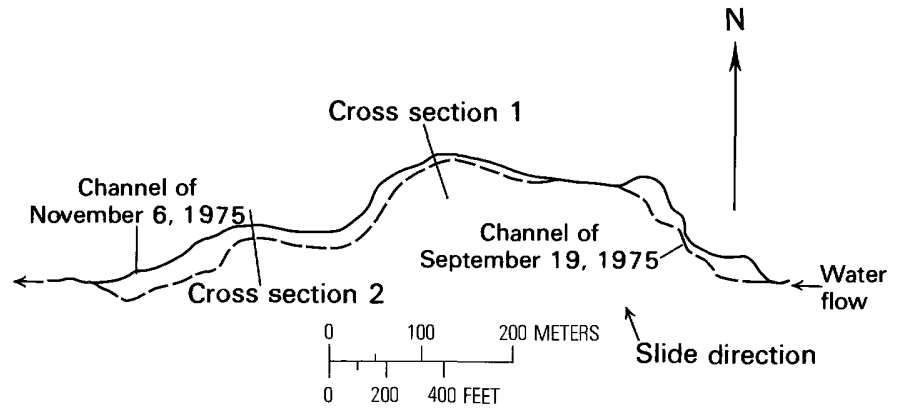

Figure 16.-Lateral displacement of Manti Creek slide reach from September 19 to November 6, 1975.

$$
A=A_{a}+\left(\frac{C}{T-T_{a}}\right),
$$

where $A$ is cumulative average channel aggradation per meter of channel length along the slide reach, in meters; the subscript $a$ indicates asympotes (also constants); $C$ is a constant; and $T$ is elapsed time since the introduction of sediment from the landslide, in years. Values for the three constants were obtained by curve-fitting computations, yielding

$$
A=14.8 \quad\left(\frac{-1.3}{T+0.1}\right)
$$

The trend and shape of such aggradation-time curves,

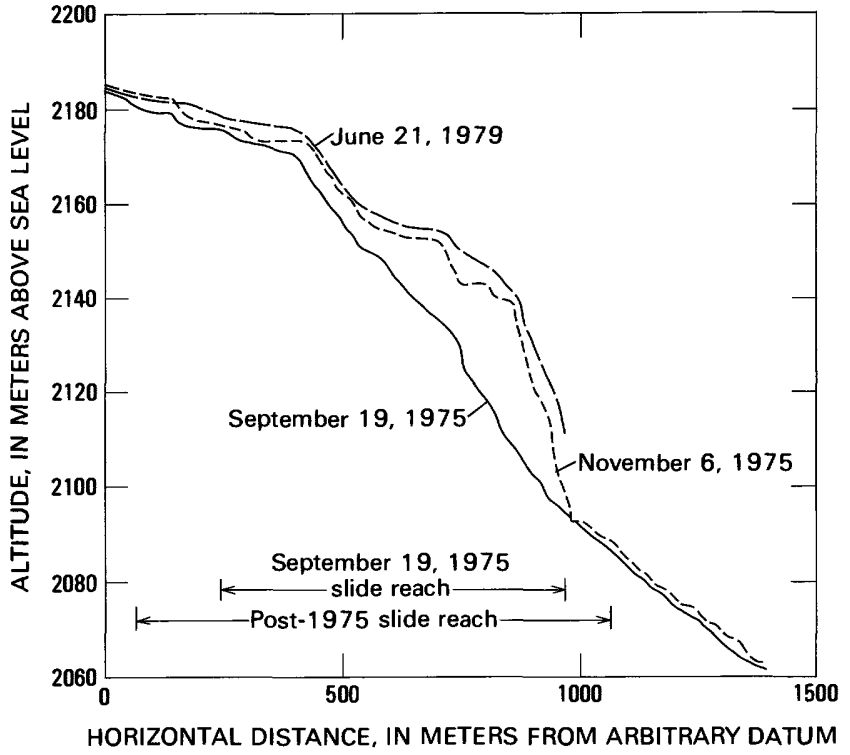

Figure 17.-Longitudinal profiles of Manti Creek in the vicinity of the landslide.

as well as the constants in the equation, could vary from one event to the next and from one landslide site to another. Even the possible general applicability of the hyperbolic curve only can be determined by similar measurements on channels at the toes of many other landslides. Measurements during the first days and weeks after the onset of aggradation (the steep part of the curve) will be especially critical in defining the curve. 


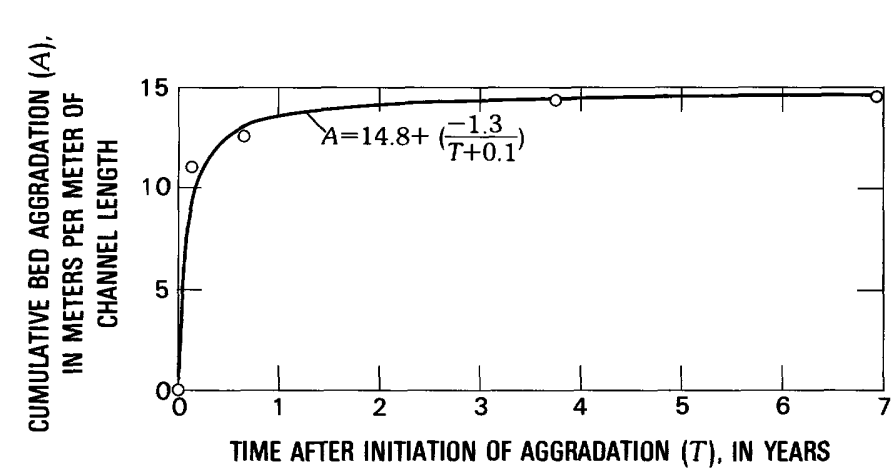

FIGURE 18.-Cumulative Manti Creek aggradation as averaged over the slide reach, for the first 7 years after the onset of aggradation (September 19, 1975, to July 28, 1982).

If the aggradation as of the July 28,1982 , onsite survey was approximately complete (an average of 14.6 $\mathrm{m} / \mathrm{m}$ of channel length), a curve of the sort shown in figure 17 can be made dimensionless and standardized for plotting on the same graph with other aggradationtime curves. The maximum time required for completion of aggradation $\left(T_{\max }\right)$ then would be $6.94 \mathrm{yr}$ (about $7 \mathrm{yr}$ ) for the landslide studied here. Values plotted on the standardized abscissa become $T / T_{\max }$ and range from 0 to 1.0. Similarly, values plotted on the ordinate are $A / A_{\max }$, where $A_{\max }$ is the final amount of aggradation, averaged for the slide reach. This final value of $A_{\max }$ would be $14.8 \mathrm{~m} / \mathrm{m}$ according to the fitted equation; whether $14.6 \mathrm{~m} / \mathrm{m}$ (the 1982 value) or $14.8 \mathrm{~m} / \mathrm{m}$ (the asymptote) is used does not make any significant difference in the curve derived.

The dimensionless, standardized plot of cumulative Manti Creek aggradation is shown in figure 19. About 80 percent of the eventual total aggradation occurred during the first 5 percent of the 7-year period of activity $\left(T / T_{\max }=0.05\right)$; in other words, during the first 4 mo or so after significant deposition began. About 95 percent of the total aggradation was completed after about 40 percent of the time ( $2.8 \mathrm{yr})$ had elapsed.

The maximum channel aggradation of $35 \mathrm{~m}$ ranks among the largest reported amounts of channel fill due to landslides. The fast, catastrophic 1959 slide into the Madison River in Montana filled that channel by about 60-120 m (U.S. Army Corps of Engineers, 1960). The bed of the Gros Ventre River in Wyoming was elevated about $55 \mathrm{~m}$ by the famous landslide of 1925 (Emerson, 1925). Lane (1955) mentioned that sediment from landslides raised the bed of the Mu Kwa River in Formosa about $12 \mathrm{~m}$ during a 3-yr period, although it is unclear whether this was deposited fluvially or directly from the slides.

The relatively insignificant or minor retrogression toward original channel elevations during the $7 \mathrm{yr}$ since the landslide, together with the cobble and boulder bed

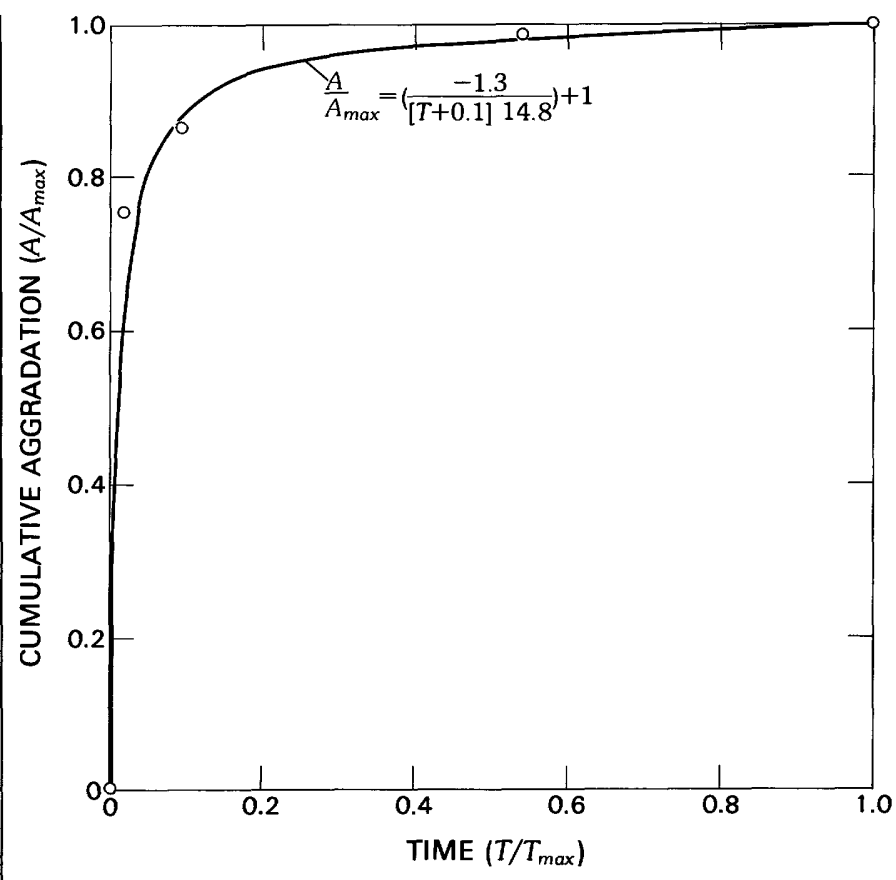

FIGURE 19.-Standardized plot of cumulative Manti Creek aggradation (averaged over the slide reach) versus time. Data are same as those used for figure 18 .

material present in 1982, shows that landslides can have a profound and long-lasting local effect on a stream channel. Unless prolonged flows capable of moving boulders $4 \mathrm{~m}$ in diameter on the present gradients occur, the channel probably never will revert to its pre-1975 profile and elevations. Channel armoring is discussed in the following section. (The bed in a $10-\mathrm{m}$-long zone at the downstream end of the third braided reach has been anchored artificially by gabions installed about 1976; however, the effect of this local feature on the profile probably is insignificant compared to the effect of the landslide sediment.)

The plotted profiles show that the channel elevation just upstream and downstream from the slide reach was not affected significantly by the slide. The changes in local gradient and in the longitudinal profile were limited to the $1,000-\mathrm{m}$-long slide reach. Within this reach, the maximum aggradation of $35 \mathrm{~m}$, about $30 \mathrm{~m}$ of which occurred during $11 / 2$ months, represents a tremendous local fluvial-geomorphic change. Such changes may be common on streams in landslide-prone areas.

\section{BED ARMORING AND SEDIMENT TRANSPORT}

The bed of Manti Creek along the slide reach was noticeably armored with large particles as of 1982 (and probably several years earlier). (Kelsey, 1978, mentioned similar armoring in streams adjacent to earthflows in 
northern California.) Braided reaches and cascades in Manti Creek each had distinctive particle sizes, the braided reaches having pebbles and small cobbles and the cascades having large cobbles and boulders. Moreover, the bed as of 1982 was no longer cohesionless. Pebbles and smaller cobbles, though partly rounded, tended to be either partially cemented in place by a thin (1-2 $\mathrm{mm}$ ) surface coating or densely imbricated in position. Large cobbles and boulders generally were very angular and tended to be wedged firmly in cracks between rocks or protected in the lee of larger boulders or both. Therefore, most of these cobbles and boulders would be difficult to move, even by high flows, and they are a degradation control along much of the slide reach. Future degradation of the present channel because of streamflows, therefore, probably will be minimal in the slide reach, as mentioned previously. In fact, bed elevations do not seem to have changed significantly since about 1976.

A sediment-transport analysis to estimate the quantities of sediment removed from the reach would be informative but would require some knowledge of the bed-material size-frequency distribution. In view of 1982 armoring and the vastly different frequency distribution of sediment initially introduced (fig. 11), the bed-material size-frequency distribution changed significantly with time after 1975 . Such changes complicate or prevent any reliable analysis of sediment transport as a function of flow hydraulics.

Nuffer (1977) summarized several pertinent observations regarding sediment transport in Manti Creek. No data on sediment concentrations were collected prior to 1975; however, local farmers said that irrigation water from Manti Creek did not present any sediment problems prior to 1975. Various observations indicate that sediment transport increased noticeably during the fall of 1975 and that it was greater then than during subsequent periods. An unknown amount of sediment was deposited downstream from the slide reach in a powerhouse diversion canal near the mouth of the canyon, in irrigation laterals, and in crop furrows during the fall of 1975 . Six water samples collected from Manti Creek during October and November 1975 showed concentrations ranging from 3,800 to $10,800 \mathrm{mg} / \mathrm{L}$ (milligrams per liter). During 1976, weekly samples were taken from late April to late August at stations a few tens of meters upstream and downstream from the slide reach. Suspended-sediment concentrations during 1976 were somewhat less than during late 1975; those at the bridge just upstream from the slide reach were consistently low (less than about $100 \mathrm{mg} / \mathrm{L}$ ) in 1976 . Those just downstream from the slide reach rose from about $500 \mathrm{mg} / \mathrm{L}$ on April 28,1976 , to about $3,300 \mathrm{mg} / \mathrm{L}$ during mid-May. Concentrations then decreased sharply for the next few weeks. By mid-June, they had decreased to about $100 \mathrm{mg} / \mathrm{L}$ and remained at this low level through the end of the sampling period (late August 1976). Additional samples taken within the slide reach from June 24 to September 27, 1976, show concentrations less than about $200 \mathrm{mg} / \mathrm{L}$. Sediment concentrations apparently have not been measured since that time.

These observations on suspended-sediment concentrations indicate that the concentrations changed in magnitude very approximately in proportion to the rate of sediment influx from the slide. The increase in sediment transport also occurred approximately synchronously with the sediment influx from the landslide. The longitudinal profiles of various dates showed no profile changes downstream from the slide reach through May 1976, which is the latest date on which such downstream profile segments could be measured. The deposits near the mouth of the canyon and beyond also consisted primarily of fine material. Therefore, most of the cobbles and boulders introduced by the landslide probably were not moved out of the slide reach. Onsite ground photographs taken in October 1976 by CH2M Hill Engineers show that the cascade subreaches were well armored at that time. Bed armor therefore was restored within about a year or less after the 1975 sediment introduction. Whether the armor is only a surface feature or instead is typical of the 1982 streambed deposits for many meters below the surface is unknown.

The various zones along the slide reach have not only distinctive bed-particle sizes, but also different bed slopes. Therefore, an association can be demonstrated between a representative bed-sediment size and channel slope for the group of subreaches. In such a relation, the question is whether the slope governs the bed-sediment size or vice versa; that is, which variable is independent and which is dependent. Slope ordinarily is dependent in a laboratory flume, where a movable sediment bed is completely free to adjust its slope. Some authors, such as Rubey (1952) and Hack (1957), maintain that slope is dependent in the field also and that bed-material size is one of several governing variables to which the channel slope adjusts. In the case of the Manti landslide, slope seems to have been affected partly by fixed (unchanging) channel elevations just upstream and downstream from the slide reach and locally by the differing quantities of sediment pushed in by the landslide. In other words slope was determined partly by outside variables. Therefore, slope probably is more independent than is particle size. Without definite proof, however, the relation probably should be viewed merely as an association.

In many instances, the flow along any given reach of stream will be able to move fine sediment from the streambed but may not be able to move very large particles, especially large boulders. Under such 
circumstances, the smallest particles remaining on the bed approximately indicate the upper limit of stream competence. In each of the subreaches of the slide reach, including two zones of noticeably different bed slope within cascade 1 , I measured the intermediate axis of 11-20 of the smallest surface particles (October 1982). Measured particles were chosen subjectively as the smallest of those available on the surface. The geometric mean $\left(d_{g}\right)$ of these smallest bed particles for each subreach is listed in table 2.

The relation between the representative smallest bed particle and local channel slope is shown in figure 20 . The smallest particle diameter varies about with the 0.8 power of channel slope. For reasons just mentioned, the graph probably needs to be interpreted as an association rather than as a dependent-independent relation.

A streambed can be interpreted either as an erosional or depositional surface; that is, the surface on a given day may be the result of the winnowing of finer material from the bed or of the deposition of sediment brought in from upstream. The cascade subreaches have large boulders that definitely were pushed in laterally from the landslide rather than being transported in from upstream of the slide reach. Therefore, these subreaches have erosional beds. The pebbles and cobbles of the braided reaches could have come either from upstream of the slide reach or from the landslide itself. No lithologic analysis was made.

The ability of a stream to move sediment can be measured by the stream power per unit channel width, or unit stream power, $\omega$, in $W / \mathrm{m}^{2}$ (watts per square meter). This is computed as $\omega=\gamma Q S / W_{b}$, where $\gamma$ is specific weight of water $\left(9,800 \mathrm{~N} / \mathrm{m}^{3}\right)$ (newtons per cubic meter), $Q$ is water discharge in $\mathrm{m}^{3} / \mathrm{s}, S$ is channel slope in $\mathrm{m} / \mathrm{m}$, and $W_{b}$ here is bed width in meters. These variables have not been measured continuously or even simultaneously for the slide reach. However, their values as determined at different times permit an approximation of the unit stream power responsible for the bed armoring, at least in the cascade subreaches.

Slopes used here for the various subreaches are leastsquares fits to the elevations surveyed onsite during 1982. Average widths for the subreaches are approximations based on 1982 onsite measurements and 1982 ground photographs; as such, they are subject to greater error than might be desired but are deemed adequate for the present purpose. These data, in addition to the average diameter of the smallest bed particles, are listed in table 2.

The maximum discharge that has acted on the bed is logically the relevant flow in regard to bed armoring. Post-1974 year-round flow records for Manti Creek are available for September 1978 to the time of this analysis (October 1982). These flows were measured at the U.S. Geological Survey gaging station about $800 \mathrm{~m}$ downstream from the lower end of the slide reach. Discharge also is measured every year from April to October, just upstream from the mouth of the canyon, by the Manti Irrigation Company. The flow at this site is not significantly different from that in the slide reach. The annual peak flow occurs during May or June, so the combined available records for the two measuring sites include the annual peak for each year. The peak discharge for $1975-82$ was $13.6 \mathrm{~m}^{3} / \mathrm{s}$ on June 11,1980 . I used this measurement as a basis for determining the discharge to be used in computing unit stream power.

Not all of a stream's discharge acts on its bed; some acts on its banks. For cross sections 1 and 2, which are in cascade reaches, a standard step-backwater analysis (Shearman, 1976) indicated that about 90-92 percent

TABLE 2.-Channel properties along the slide reach [mm, millimeters; $\mathrm{m} / \mathrm{m}$, meters per meter; $\mathrm{m}$, meters; $\mathrm{W} / \mathrm{m}^{2}$, watts per square meter]

\begin{tabular}{|c|c|c|c|c|}
\hline Subreach & $\begin{array}{l}\text { Average } \\
\text { diameter, dg, } \\
\text { of smallest } \\
\text { bed particles } \\
\text { (mm) }\end{array}$ & $\begin{array}{c}\text { Channel } \\
\text { slope } \\
(\mathrm{m} / \mathrm{m})\end{array}$ & $\begin{array}{l}\text { Approximate } \\
\text { bed width } \\
\text { (m) }\end{array}$ & $\begin{array}{l}\text { Approximate } \\
\text { highest } \\
\text { unit } \\
\text { stream } \\
\text { power } \\
\left(\mathrm{W} / \mathrm{m}^{2}\right)\end{array}$ \\
\hline First braided reach-- & 23 & 0.015 & 30 & 65 \\
\hline Cascade l (upper part) & 113 & .13 & 8 & 1,950 \\
\hline Cascade 1 (lower part) & 95 & .058 & 8 & 890 \\
\hline Second braided reach- & 27 & .035 & 35 & 130 \\
\hline Cascade 2--_- & 118 & .092 & 8 & 1,380 \\
\hline Third braided reach-- & 35 & .026 & 30 & 115 \\
\hline Cascade 3--- & 150 & .23 & 10 & 2,800 \\
\hline
\end{tabular}




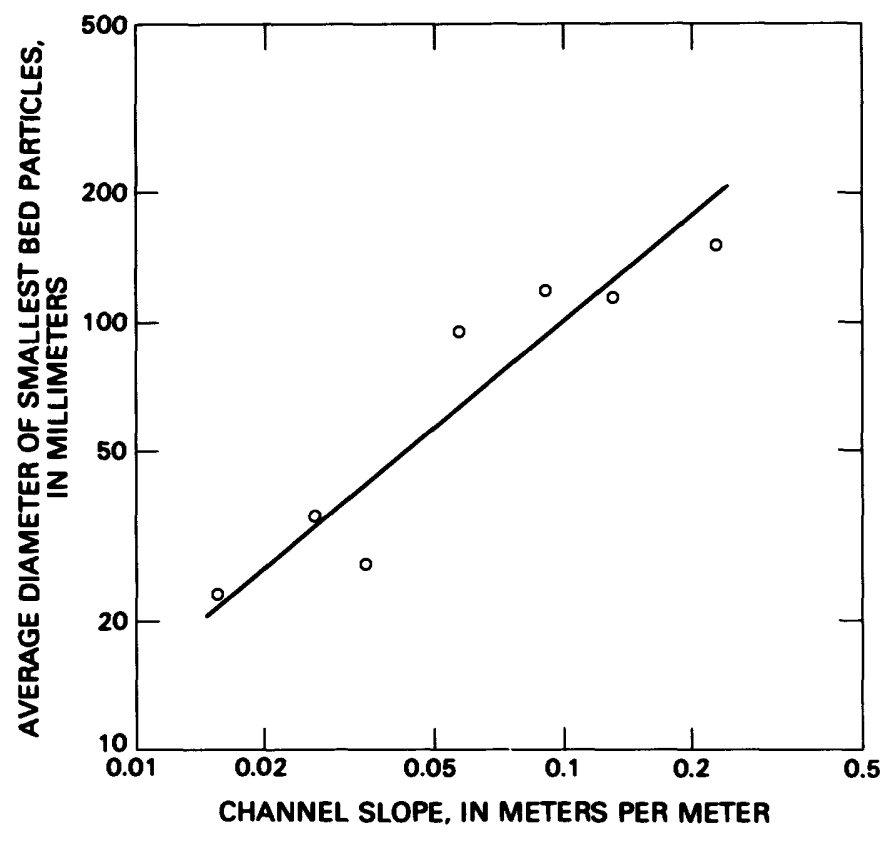

Figure 20.-Geometric mean diameter of smallest bed particles as a function of local channel slope in the various subreaches of the Manti Creek slide reach. Fitted line is the reduced major axis.

of the $13.6 \mathrm{~m}^{3} / \mathrm{s}$ affected just the bed. This amount of adjustment, therefore, was applied to all cascade subreaches. Braided reaches have much greater width/ depth ratios than do cascades, and I have assumed that all of the $13.6 \mathrm{~m}^{3} / \mathrm{s}$ acted on the bed in braided zones. The estimated highest unit stream powers, using these adjusted discharges and other pertinent data, are listed in table 2.

The average diameter of the smallest bed particles as a function of the approximate highest unit stream power is shown in figure 21 . The graph implies that a given unit stream power was able to remove bed particles smaller than the size indicated. This approach assumes that the 1982 bed in the braided zones reflects stream competence and is not simply a deposit of a previous peak flow. There is also an unknown amount of error or uncertainty in the plotted particle-size values and in $Q, S$, and $W_{b}$. Many unassessed factors, such as shielding, particle shape and roundness, particle specific gravity, and bed configuration affect the movement of a particle of a given diameter. For all of these reasons, the relation can be considered only very approximate at best.

\section{SUMMARY}

The small stream on the landslide maintained its approximate general position and route on the slide

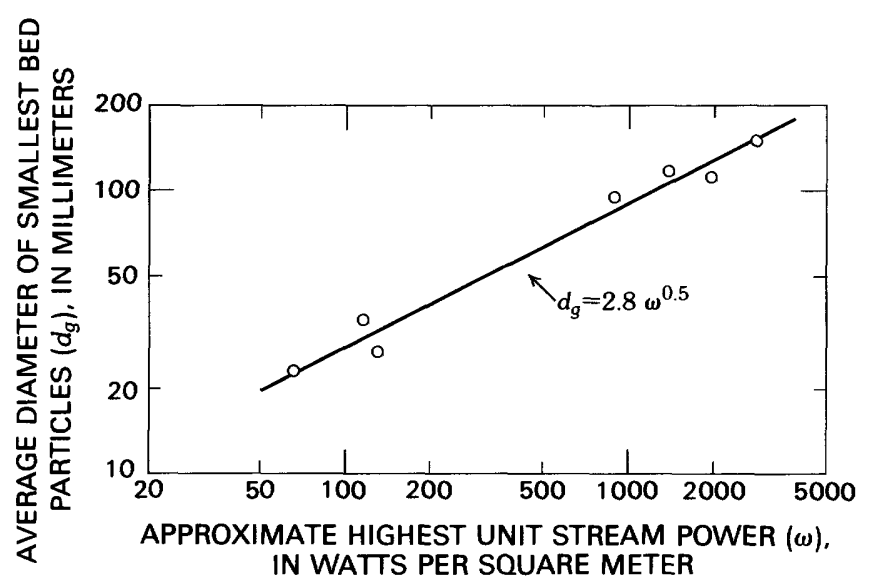

FIGURE 21.-Average smallest bed-material diameter as a function of approximate highest unit stream power that acted on the postslide streambed. Line fitted by least squares.

surface throughout the period of landslide movement. The sliding obliterated nearly all of the few pre-1974 ponds but created about 63 new ponds on the landslide surface. Most of these new ponds are in the lower half of the landslide and as of 1982 appeared to be rather permanently established. They are of two types: open ponds within the stream system and closed ponds having no apparent slide-surface inflow or outflow. In contrast to the pre-1974 ponds, nearly all of them tend to have irregular shapes and perimeters. Ponds in the upper half of the landslide formed within $1 \mathrm{yr}$ or less after the active front of the landslide passed through their area (about 1-2 yr after the June 6, 1974, failure). Ponds in the downslope half of the landslide formed within 0-4 yr after the landslide first disrupted their area (about 1-5 yr after the June 6, 1974, failure).

Manti Creek, at the toe of the landslide, was reduced in size (top width, bed width, channel depth, and channel cross-sectional area) by the sediment pushed in by the slide. Only bed width in certain subreaches had managed a significant post-slide recovery by 1982 . The area of cross section 1 was reduced to about 60 percent of its pre-1974 cross-sectional area; cross section 2 probably was reduced by a greater proportion. From September 19 to November 6, 1975, the period when most of the sediment was introduced into Manti Creek, the creek was displaced laterally by distances of as much as $33 \mathrm{~m}$, averaging $15 \mathrm{~m}$.

Channel aggradation ranged from a meter or two to $35 \mathrm{~m}$, averaging nearly $15 \mathrm{~m}$. Aggradation as averaged for the slide reach took place very rapidly at first, then slowed considerably and became asymptotic toward a limiting value as time progressed and as landslide 
movement waned. A hyperbolic curve describes this trend. Such a curve can be standardized for comparison with aggradation on other streambeds, if a hyperbolic curve also applies to the latter. The maximum aggradation of $35 \mathrm{~m}$ at one site within the slide reach is among the largest reported amounts of channel fill because of landslides; larger amounts very probably have occurred elsewhere but have not been measured and reported. Because of the armoring boulders and cobbles that covered much of the streambed in 1982, the landslide seems to have introduced a semi-permanent change (hump) into the longitudinal profile of the streambed.

Suspended-sediment concentrations in Manti Creek adjacent to, and downstream from, the landslide seem to have increased only during the fall of 1975 when the slide was most rapidly pushing material into the stream. As of 1982, the smallest bed-particle diameters varied with the local slope of the streambed and with the unit stream power estimated to have acted on the post-slide streambed.

Ponds formed by landslides provide an excellent opportunity to study new ponds and to study the many aspects of a pond's hydrologic, physiographic, chemical, botanical, zoologic, and other development with time. For example, no studies seem to have been made of the algal and higher plant communities of the new ponds on the Manti landslide, nor of the animal communities (including insects), microclimate, radiation regime, water chemistry, character of the pond beds, transpiration and water exchange, and other features. Of particular interest for the Manti landslide would be the water balance of the closed ponds; in other words, the way in which the ponds are maintained. Where many ponds have been formed by a landslide, the approximate date of landslide movement might be estimated from pond sediments. Such methods, if proven feasible, might even be used to reconstruct the history or frequency of landslide activity in entire regions.

\section{REFERENCES CITED}

Adam, D. P., 1975, A late Holocene pollen record from Pearson's Pond,
Weeks Creek Landslide, San Francisco Peninsula, California: U.S. Geological Survey Journal of Research, v. 3, no. 6, p. 721-731.

Bailey, R. G., 1971, Landslide hazards related to land use planning in Teton National Forest, northwest Wyoming: Ogden, Utah, U.S. Forest Service, 131 p.

Cloud, T. A., 1981, Temporal and spatial distribution of landslides, Gros Ventre River valley, Gros Ventre mountains, Wyoming: Ames, Iowa, Iowa State University M.S. thesis, 98 p.

Emerson, F. B., 1925, 180-ft. dam formed by landshide in Gros Ventre Canyon: Engineering News-Record, v. 95, no. 12, p. 467-468.

Fleming, R. W., Schuster, R. L., Johnson, R. B., and Robinson, S. L., 1977, Recent movement of the Manti, Utah, landslide: Annual Symposium on Engineering Geology and Soils Engineering, 15th, Pocatello, Idaho, April 7, 1977, Proceedings, p. 161-178.

Hack, J. T., 1957, Studies of longitudinal stream profiles in Virginia and Maryland: U.S. Geological Survey Professional Paper 294-B, p. 45-97.

Kelsey, H. M., 1978, Earthflows in Franciscan melange, Van Duzen River basin, California: Geology, v. 6, no. 6, p. 361-364.

Lane, E. W., 1955, The importance of fluvial morphology in hydraulic engineering: Proceedings of the American Society of Civil Engineers, v. 81, Separate Paper no. 745, 17 p.

Nuffer, S. S., 1977, A study to reduce the effects of the Cottonwood Landflow: Boise, Idaho, CH2M Hill Engineers, 97 p.

Olson, E. P., 1975, Reduced flood potential-Manti Canyon: Ogden, Utah, U.S. Forest Service, 8 p.

1977, Burnt Hill landslides, part 1 of Landslide investigation, Manti Canyon: U.S. Department of Agriculture, Forest Service, Report G-R4-77-2, May 3, 1977, 26 p.

1978, Cottonwood complex, part 2 of Landslide investigation, Manti Canyon: U.S. Department of Agriculture, Forest Service, Report G-R4-78-2, April 13, 1978, 53 p.

Robinson, S. L., 1977, Geologic analysis of the Manti Landslide, Manti, Utah: Fort Collins, Colorado, Colorado State University M.S. thesis, $103 \mathrm{p}$.

Rubey, W. W., 1952, Geology and mineral resources of the Hardin and Brussels quadrangles (in Illinois): U.S. Geological Survey Professional Paper 218, 179 p.

Schuster, R. L., 1978, Introduction, in Schuster, R. L., and Krizek, R. J., eds., Landslides-analysis and control: Washington, D.C., National Research Council Transportation Research Board Special Report 176, $234 \mathrm{p}$.

Shearman, J. O., 1976, Computer applications for step-backwater and floodway analyses: U.S. Geological Survey Open-File Report 76-499, $119 \mathrm{p}$.

U.S. Army Corps of Engineers, 1960, Madison River, Montana, report on flood emergency, Madison River slide, volume 1-Main report: Omaha, Nebraska, U.S. Army Engineer District, 28 p.

Winter; T. C., and Wright, H. E., Jr., 1977, Paleohydrologic phenomena recorded by lake sediments: EOS, Transactions of the American Geophysical Union, v. 58, no. 3, p. 188-196.

Woolley, R. R., 1946, Cloudburst floods in Utah, 1850-1938: U.S. Geological Survey Water-Supply Paper 994, 128 p. 